Borbásné Szabó Ildikó

\title{
Felsőoktatási portfolió kompetencia alapon történő tervezése
}




\section{INFORMÁCIÓRENDSZEREK TANSZÉK}

Témavezető: Dr. Gábor András

C Borbásné Szabó Ildikó 
DOI: 10.14267/phd.2014005

BUDAPESTI CORVINUS EGYETEM

GAZDÁLKODÁSTANI DOKTORI ISKOLA

\title{
Felsőoktatási portfolió kompetencia alapon történő tervezése
}

Ph.D. értekezés

\author{
Készítette: \\ Borbásné Szabó Ildikó \\ BCE, Információrendszerek Tanszék
}

Budapest, 2012 
DOI: 10.14267/phd.2014005 


\section{Tartalomjegyzék}

ÁBRÁK JEGYZÉKE ..................................................................................... ii

TÁBLÁZATOK JEGYZÉKE ..........................................................................iii

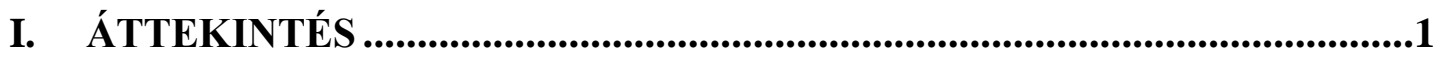

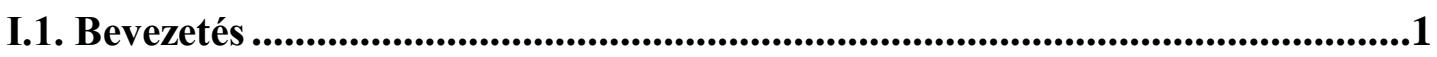

I.2. A kutatás problémaköre.......................................................................................2

I.3. A kutatás tárgya ..................................................................................................4

I.3.1 A kutatás tárgykörben történő elhelyezése ....................................................

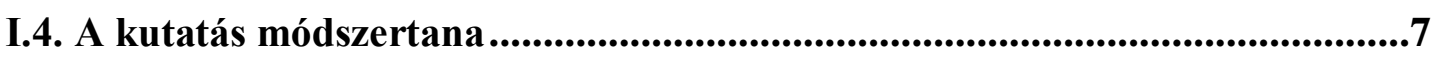

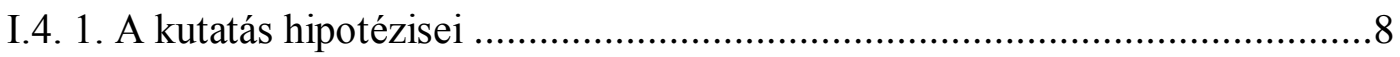

I.5. A kutatás jelentősége, hasznai ..........................................................................10

I.6. A dolgozat sajátosságai, felépítése....................................................................11

II. KOMPETENCIA - ELMÉLETI HÁTTÉR ..................................................12

II.1. A kompetencia szerepe a munkaerốpiac keresleti oldalán .............................12

II.2. A kompetencia szerepe a munkaerőpiac kínálati oldalán ..............................13

II.3. A kompetencia fogalma ..............................................................................16

II.4. Kompetenciamodellek...................................................................................18

II.4.1. HLD kompetenciamodell ...............................................................

II.4.2. ETA (Employment and Training Administration) kompetencia-modell .....20

II.4.3. Spencer-féle kompetenciaszótár ............................................................22

II.4.4. Management Charter Initiative ……………………….........................2

II.5. Képesítési keretrendszerek .............................................................................25

II.5.1. Nemzeti Szakmai Képesítés (National Vocational Qualifications) .............25

II.5.2. Európai Felsőoktatási Térség keretrendszere ..............................................26

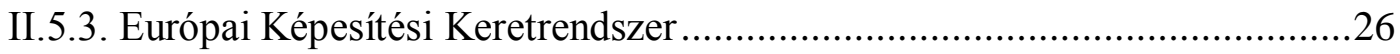

II.5.4. Országos Képesitési Keretrendszer (OKKR) ............................................28

II.6. A kompetencia használhatósága a kutatásban...............................................29

III. ONTOLÓGIA ALAPÚ MEGKÖZELÍTÉS..................................................32

III.1. Az ontológia fogalma ..............................................................................................32 
IV. AZ INFORMATIKAI RENDSZER FEJLESZTÉSE 35

IV. 1. A fejlesztés első fázisa: szakterületi ontológiák kialakítása .........................36

IV.1.1. Szakterületi ontológia fejlesztését megalapozó kutatások............................37

IV.1.2. Kompetencia meta-modellek ..............................................................41

IV.1.3. Ontológia formalizálását elösegítő eszközök...........................................43

IV.1.4. A Képzési Kimeneti Követelmény Ontológiára épülö szakmastruktúra

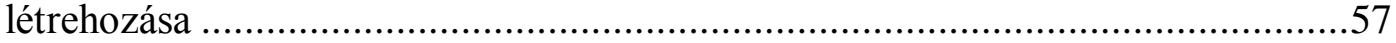

IV.1.5. A Munkaköri Leírás Ontológiára épülő foglalkozási struktúra létrehozása

IV.1.6. Az első fejlesztési szakasz értékelése ....................................................79

IV.2. A fejlesztés második fázisa: az ontológiák egymáshoz illesztése .................79

IV.2.1. Ontológiák egymáshoz illesztése, kezelése …………………………....... 80

IV.2.2. A KKKO és MLO ontológiák összeillesztése.........................................91

IV.2.3. A második fejlesztési szakasz értékelése ................................................94

V. A RENDSZER INTEGRÁLHATÓSÁGÁNAK VIZSGÁLATA .....................96

VI. A KUTATÁS TAPASZTALATAI....................................................................97

VII. IRODALOMJEGYZÉK .................................................................................103

VIII. FÜGGELÉK ....................................................................................................112 


\section{Ábrák jegyzéke}

1. ábra HLD-féle kompetenciamodell (Henczi, 2009 pp.14) 20

2. ábra ETA kompetenciamodell (Ennis, 2008 pp.7) 21

3. ábra MIC NVQ-n alapuló felépítése 24

4. ábra Különböző képesítések összehasonlítása az EKKR alapján (Anon, 2009) 27

5. ábra Inkrementális fejlesztés folyamata 35

6. ábra Kompetencia Ontológia (Draganidis és Mentzas, 2006 pp.4) 38

7. ábra HR ontológia felépítése (Mochol et al., 2004 pp.4) 39

8. ábra Felsőoktatási alapontológia 39

9. ábra Munkaköri Ontológia Modell felépítése 40

10. ábra Munkaköri Leírás Ontológia és a Képzési Kimeneti Követelmény Ontológia 42

11. ábra BCE Gazdaságinformatikus BSC képzés tudáselemei 58

12. ábra A KKKO ontológia Protégé 4.1-ben való implementációja 58

13. ábra 2009. októberében igényelt szerepkörök 61

14. ábra 2010. augusztus és szeptember közepe között igényelt szerepkörök 61

15. ábra 2012. októberében igényelt szerepkörök 62

16. ábra Meta-modell Protégé 4.1-ben 64

17. ábra XHTML fájl feldolgozásának folyamata 66

18. ábra Új osztályokkal módosított Protégé ontológia 70

19. ábra MLO Feladat osztályának hierarchiája 72

20. ábra Vállalati architektúráért felelős személytől elvárt ismeretek 76

21. ábra MLO kompetenciákkal bővített vázlatos hierarchiája 77

$\begin{array}{ll}\text { 22. ábra Példányosított tudásterületek } & 78\end{array}$

23. ábra Összehasonlítás eredménye Compare Ontologies menüpont segítségével 91

24. ábra Egyező és eltérő tudásterületek feltárása OWL Diff segítségével 92

25. ábra Egyező és eltérő példányok feltárása OWL Diff segítségével 92

26. ábra Axiómabeli különbségek jelölése 93 


\section{Táblázatok jegyzéke}

1. táblázat Spencer-féle kompetenciaszótár 23

2. táblázat A kompetenciamodellek összehasonlítási alapként való vizsgálata $\quad 30$

3. táblázat Általános jellemzök $\quad 54$

4. táblázat Automatikus adatimportálás 55

5. táblázat Automatikus illeszkedésvizsgálat $\quad 56$

6. táblázat A szerepekörök vizsgált időszakban való abszolút megoszlása $\quad 60$

7. táblázat Szoftverfejlesztői munkakörhöz kapcsolódó osztályok 63

8. táblázat Alkalmazott nyitott kérdések 68

9. táblázat Nem fejlesztői szerepkörhöz tartozó feladatok 69

10. táblázat Fejlesztői szerepkörhöz kapcsolódó újabb feladatok 69

11. táblázat A besorolt alosztályok értékelése 71

12. táblázat A vállalati architekt alkalmazási tárgyterülethez kapcsolódó kompetenciái 75

13. táblázat Találatok megoszlása 78

14. táblázat Ontológiaillesztést elősegítő eszközök értékelése 90

15. táblázat A két oldal egyezőségének és különbözőségének tételes feltárása 94

16. táblázat A rendszer erősségei és gyengeségei 101 


\section{Köszönetnyilvánítás}

Köszönetet szeretnék mondani a témavezetőmnek, Dr. Gábor Andrásnak a folyamatos segítségnyújtásért, szakmai támogatásért, valamint azért, hogy egy olyan témát talált ki a számomra, amellyel öröm volt foglalkozni, mert bár sok nehézséget rejtett, ezek megoldása számos sikerélménnyel és új ismeretekkel járt.

A dolgozat elkészítésében nagy segítséget jelentett Vas Réka értékes véleménye, amivel tovább lendített, Kovács Barna elgondolása a módszertannal kapcsolatban, valamint férjem, Borbás Gergely szakmai tanácsa, amivel egyszerübbé vált a programozás.

Szeretném megköszönni Kö Andreának, hogy 2005-ben bevont a projektekbe, s ezáltal megalapozta a jövőmet a felsőoktatásban. Köszönöm szépen a kollégáimnak, az Információrendszerek Tanszék munkatársainak, hogy lelkesítettek, ötleteket adtak, Ternai Katalinnak és Kovács Barnának a fordításban való közremüködést. Köszönetet szeretnék mondani a családomnak, a nővéremnek, Erikának, hogy segítőkészségükkel, kedvességükkel hozzásegítettek a tézis megírásához. 


\section{I. Áttekintés}

\section{I.1. Bevezetés}

Mind nemzetközi, mind hazai szinten olyan tendenciák érzékelhetők, amelyek a felsőoktatás munkaerő-piaci igényeknek megfelelő átstrukturálását igénylik. Az erre irányuló közigazgatási döntés-előkészítési folyamat implementálására egy ontológia alapú rendszer keretei között került sor a SAKE projekten belül. Az OntoHR projekt is ontológiai megközelítésen alapuló kiválasztási és képzési rendszerre építve kívánja megtalálni a legkompetensebb állásra jelentkezőt, valamint az adott munkakörhöz jobban illeszkedő képzési struktúrát. Mindkét rendszer kompetencia alapon végzi el a munkaerőpiac keresleti, illetve kínálati oldalának képzettség tekintetében történő összehasonlítását.

Dolgozatom ezen projektek eredményeire építve, azonban azokat kiegészítve arra fókuszál, hogy hogyan tudjuk az aktuális munkaerőpiaci-igényeket a lehető legszéleskörübb dokumentumbázisra építve automatikusan feldolgozni, ezt a fennálló képzési struktúrával összehasonlítani, illetve az így kialakított rendszert a felsőoktatási döntés-előkészítési folyamatba beilleszteni. A doktori disszertáció az erőforrások szűkössége miatt a koncepció használhatóságát kívánja bemutatni. Így a kidolgozott rendszer a munkaerő-piaci keresleti igények teljes körü feldolgozása helyett a Budapesti Corvinus Egyetem Gazdaságinformatikus BSc képzésére, illetve a hozzá kapcsolódó Szoftverfejlesztő munkakörre építve lett kialakítva. A rendszer fejlesztése során az inkrementális rendszerfejlesztési folyamatot követtem, amelyen belül két fázist vittem véghez. Az első fázisban a képzési oldal kompetenciaelemeit reprezentáló Képzési Kimeneti Követelmény Ontológia kialakítására és implementálására került sor. Mindemellett Java programnyelvben (DOS batch fájlokkal egybeépítve) implementáltam azt az algoritmust, amely a széles adathalmazt és azok automatikus feldolgozhatóságát biztosító állásajánlatokat emberi segítség nélkül legyüjti, relevancia alapján megszüri, valamint az ebben a fázisban létrehozott Munkaköri Leírás Ontológia meta-modelljét kiegészíti, illetve a meglévő osztályait validálja, példányosítja. Azonban a természetes nyelvi feldolgozó algoritmusok ekkora adathalmazon még 
nem képesek 100\%-os pontosságú feldolgozásra, ezért a modell felépítése, valamint a validálása után szükség volt a Dr. Gábor András által biztosított szakértői revízióra. Az ontológiaszerkesztő környezetek több szempontból való megvizsgálása után az ontológiák fent vázolt implementációjára a Protégé 4.1 környezetet választottam ki.

A fejlesztés második fázisban az ontológiaillesztő eszközök használhatósági elemzése után a két ontológia összehasonlításának tekintetében a Protégé 4.2 ontológiafejlesztő környezet beépített alkalmazásai mellett döntöttem. Ezek segítségével megvizsgáltam a két ontológia tudást reprezentáló osztályának - az aktuális helyhez, időhöz és tudásszinthez tartozó - példányainak különbözőségeit és egyezőségét. Ezzel bemutattam azt, hogy kidolgozható egy olyan rendszer, amely kompetencia alapon képes összehasonlítani a munkaerőpiac két oldalát. Vagyis a felsőoktatási portfoliónk egyik eleme, a Gazdaságinformatikus képzés állásajánlatokban megjelenő piaci igényeknek való megfelelősségi vizsgálatára került sor.

Ez a rendszer tetszőleges képzésre vonatkozóan implementálható, az aktuális állásajánlatok függvényében megváltoztatható, illetve bővíthető, azonban a keresleti oldalon megjelenő kompetenciák előrejelzésére még nem képes. A rendszer nyitottságának köszönhetően a jövőben erre vonatkozó funkcióval szabadon kibővíthető. Az így kialakított rendszer - bizonyos korlátok között - a felsőoktatási keretszámokat érintő döntés-előkészítési tevékenységekhez hasznos információkat tud szállítani.

Bár a munkaerő-piaci igények kompetencia alapon történő adaptálása a képzések kialakítása során versenyképessebbé teheti a felsőoktatást, azonban ez a szemlélet a jelenlegi döntés-előkészítési folyamatokban nem tesztelhető.

\section{I.2. A kutatás problémaköre}

A gazdasági versenyképesség fenntartásának egyik feltétele a releváns tudás megfelelő időben, megfelelő helyre történő eljuttatása, felhasználása. Ez makrogazdasági szinten többek között a munkaerő szabad áramlását, valamint versenyképes oktatási térség létrehozását foglalja magában.

Az Európai Unió az ilyen irányultságú integrációs folyamatok megvalósíthatósága érdekében az 1997-ben ratifikált Amszterdami szerződésben „összehangolt foglalkoztatási stratégia" megteremtését tủzte ki célul, míg az 1999. június 19-én Európa oktatási miniszterei által aláírt Bolognai Nyilatkozatban kijelölték azokat a föbb 
irányelveket, amelyeket követve versenyképes Európai Felsőoktatási Térség ${ }^{1}$ jöhet létre. Többek között - a nemzeti tradicionális oktatási jellemzők megsértése nélkül célul tüzték ki az élethosszig tartó tanulás elősegítését, könnyen érthető és összehasonlítható fokozatok bevezetését, a hallgatók és a végzettek mobilitásának elősegítését, európai dimenziók megjelenését az oktatásban, valamint minőségbiztosítási rendszer kidolgozását (European Commission, 1999).

A pénzügyi és gazdasági válság is rámutatott annak a fontosságára, hogy a felsőoktatási intézmények olyan hallgatókat képezzenek, akik rugalmasan tudnak alkalmazkodni a változó környezeti feltételekhez, beleértve itt a képzés évei alatt megszerzett széleskörü tudás alkalmazását, valamint a hiányzó, vagy részleges tudáselemek egyéni hatáskörben történő fejlesztését. A változó munkaerőpiacon szükséges kompetenciák megszerzését tanulóközpontú oktatás, valamint mobilitás biztosítja a számukra. Mindemellett szükség van arra is, hogy a felsőoktatási intézmények olyan erőforrásokkal rendelkezzenek, amelyek lehetővé teszik számukra „széles tudásbázis létrehozását és folyamatos bővítését, valamint a kutatás és innováció serkentését” (European Commission, 2009).

Magyarországon a kormány felismerte, hogy a Bologna-típusú rendszerben kialakított programok képzési és kimeneti követelményei nem tükrözik híven a munkaerőpiaci követelményeket. Figyelembe vették az ebbe az irányba mutató, a struktúra tarthatatlanságára utaló alábbi jeleket:

- súlyponti eltolódás a jogi, menedzsment, bölcsész, művészeti tudományok javára, a munkaerőpiac által inkább igényelt mérnöki-, vagy alkalmazott tudományok helyett

- a szakképzett hallgatók foglalkoztatására irányuló kínálatot meghaladó többszörös kereslet.

Ezért a napjainkban zajló „magyar felsőoktatás fejlesztésének elsődleges feladata a képzési kimenetek és a gazdasági igények közötti összhang erősítése, a képzési tartalmak minőségelvű fejlesztése, ezek eredményeként pedig a foglalkoztatás és a gazdaság versenyképességének javítása” (SZKTerv, 2012 pp.47).

\footnotetext{
${ }^{1}$ Egy olyan térség, ahol „a felsőoktatás a köz felelőssége, és ahol céljaik és küldetéseik sokszínűsége révén a felsőoktatási intézmények képesek reagálni a társadalom szélesebb értelemben vett szükségleteire." (European Commission, 2009 pp.1)
} 
Ezen jelenségek létjogosultságot adnak egy olyan rendszernek, ami azt vizsgálja meg, hogy a mai magyar felsőoktatási képzési kínálat biztosítja-e a hallgatók számára azt, hogy az egyetemi évek alatt megszerzett tudásukra alapozva zökkenőmentesen tudjanak munkába állni, vagy vannak olyan munkaerőpiacról érkező igények, amelynek nem tud megfelelni.

\section{I.3. A kutatás tárgya}

Az összes képzés feldolgozása túl komplex és időigényes feladat, ezért a kutatásom empirikus részében a feladatot úgy fogalmaztam meg, hogy a Budapesti Corvinus Egyetem Gazdaságinformatikus BSc képzése megfelel-e ennek a kihívásnak, azaz a képzés struktúrája kellően alkalmazkodik-e a változó munkaerö-piaci követelményekhez. A Gazdaságinformatikus BSc IT pozíciók betöltésére képez, azonban az erőforrások szükössége miatt csak a Szoftverfejlesztői munkakört választottam vizsgálatom alapjául. Kutatásom célja tehát olyan ontológia-alapú rendszer kidolgozása és tesztelése volt, amely segítségével első körben a képzési és kimeneti kompetenciák munkaerö-piaci aspektusból való megfelelőségi vizsgálatára kerülhet sor. Erre építve a jövőben kialakítható egy olyan rendszer, amely alapján második körben ajánlásokat lehet tenni bizonyos felsőoktatási jellemzők (finanszírozás, létszám, kapacitás) átalakítására.

\section{I.3.1 A kutatás tárgykörben történő elhelyezése}

A téma vizsgálata nem új keletü. 2006-ban az Európai Bizottság finanszírozásában megvalósított $\mathrm{SAKE}^{2}$ projekt a jogszabályi és egyéb környezeti változások által befolyásolt összetett közigazgatási szituációk teljes körű elemzését tűzte ki célul, amelyet a projekt keretén belül kidolgozott holisztikus keretrendszer és eszköz támogatott (SAKE, 2006). A rendszer magyarországi mintaesetének a célja a magyar felsőoktatás keretszámait meghatározó döntés-előkészítési folyamat implementálása volt, amelyen belül a hangsúly a felsőoktatási intézmények forrásfelhasználása és finanszírozása közötti egyensúly megteremtésére helyeződött. Mindez olyan képzési és oktatási kínálat létrehozását igényli, amely a hallgatók számára lehetővé teszi a munkaerőpiacon való zökkenőmentes munkavállalást. Más szavakkal, helyes felsőoktatási portfolió kidolgozására van szükség. A portfolió tervezési folyamatának alapeleme

\footnotetext{
${ }^{2}$ A SAKE (Szemantikailag támogatott, agilis, tudásalapú e-kormányzat, IST 027128) az Európai Unió FP6 Keretprogramja által támogatott, nemzetközi kutatási konzorcium kivitelezésében megvalósuló, három éves kutatási projekt.
} 
a munkaerőpiac keresleti oldaláról származó, 3-5 éves időtartammal előre megjósolt képzettségi igények és a munkaerőpiac kínálati oldalán megjelenő képzési struktúra összehasonlítása, majd összhangba hozása (Kovács, 2010). Tapasztalataim alapján a projekt keretében kidolgozásra került részrendszer a munkaerő-piaci igények dinamikus feldolgozása, valamint az összehasonlítás minőségének javítása terén további fejlesztésre szorult.

Az Európai Bizottság által 2009-ben útjára indított másik projekt az OntoHR ${ }^{3}$ is arra hivatott, hogy a képzettség alapján betölthető munkakörhöz jobban illeszkedő képzési struktúrára tegyen ajánlást, mindamellett, hogy egy ontológia alapú kiválasztási és képzési rendszer kidolgozásával hozzájárul a legkompetensebb állásra jelentkező megtalálásához, illetve számára esetleges továbbképzési útvonalak megadásához (Kismihók-Mol, 2011) (Mol et al., 2012). Az itt kifejlesztett rendszer sem kezeli az igények dinamikus feldolgozását, azonban tartalmaz a két oldal illeszkedését vizsgáló algoritmust. A foglalkozási és az oktatási oldal eltérő szemléletmódjának, valamint esetleges kulturális különbözőségük kezelésére mindkét oldal ontológiai megközelítést használt.

A DEHEMS projekt ${ }^{4}$ célja a végzett hallgatók korai karrierpályájának a vizsgálata, és karrier útjának az elősegítése. Ezért teremtenek meg egy olyan, tudásra fókuszáló platformot, amely a különböző felsőoktatási rendszerek kapcsolódó teljesítményének, illetve minőségbiztosításának optimalizálásra törekszik. Az elméleti keretek meghatározása és az adatelemzés után, hat országban elvégzett interjúk sorozatára alapozva mérték fel a munkavállalók igényeit (pl. a tudományos és a gyakorlati képességek egyensúlyba kerülésének az igénye a felsőoktatási képzési programokban) a felsőoktatási képzések tartalmára vonatkozóan (Melink-Pavlin, 2012).

A CEDEFOP ceurópai szakképzési fejlesztési központ is kidolgozott egy olyan módszertani keretrendszert, amely a munkaerőpiac keresleti és kínálati oldalán fellelhető gyakorlati képességek különbözőségeit kívánja előrejelzési modellek alapján meghatározni (Cedefop, 2012).

\footnotetext{
${ }^{3}$ Az OntoHR (Ontology Based Competency Matching between the Vocational Education and the WoRkplace, 504151-LLP-1-2009-1-HU-LEONARDO-LMP) Leonardo Da Vinci projekt, amely nemzetközi konzorcium részvételével 2009-ben indult útjára.

${ }^{4}$ Dehems projekt (Network for the Development of Higher Education Management System, 502890-LLP-12009-1-SI-ERASMUS-ENWS) az európai unóis Lifelong Learning Programme keretén belül indult az útjára.
} 
Kutatásomban olyan informatika rendszer fejlesztését tủztem ki célul, amely elsősorban a képzések aktuális munkaerő-piaci igényeknek való megfelelősségét vizsgálja, azonban továbbfejleszthető az esetleges előrejelzések alapján történő elemzés felé is. Mivel ez a rendszer a munkaerőpiac két oldalának eltérő szemléletmódját kívánja közös platformon összehasonlítani, ezért az OntoHR és a SAKE projektek ontológia alapú szemléletmódját követi. Az eredményeikre építve, de azokat továbbfejlesztve dinamikusan kezeli a munkaerőpiac keresleti oldaláról érkező, képzettséget érintő igények (továbbiakban munkaerő-piaci igények vagy foglalkozási struktúra) és a gazdaságinformatikus képzés képzési struktúrájának (továbbiakban szakmastruktúrának) az összehasonlítását. Dinamikus illeszkedésvizsgálaton adott időszakonként történő munkaerö-piaci igények összegyüjtését, majd ezeknek ontológia alapú módszertan szerint az oktatási oldallal történő összehasonlítását, és az eredmények értékelését értem.

Kutatásom a következő kérdéskörök köré csoportosult:

- Milyen dokumentumok és ezeket feldolgozó módszerek teszik lehetővé az igények dinamikus kezelését?

- A képzési kimeneteket leíró kompetencia fogalom valóban alkalmas-e a két oldal összehasonlítására?

- Alkalmasak-e az ontológiák a munkaerő-piaci igények, illetve a szakmastruktúra reprezentálására? Megfelelő alapot nyújtanak-e a dinamikus illeszkedésvizsgálathoz?

- Az összehasonlítás eredményéül kapott egyezőségek, illetve különbözőségek hogyan használhatóak fel a felsőoktatási keretszámot érintő döntéselőkészítési folyamatban?

Kutatási hipotéziseim a kérdéscsoportok által körvonalazott rendszer fejlesztésének alábbi fázisaihoz kapcsolódtak.

- Ontológiaépítés: a munkaerö-piaci igények változását jól leíró dokumentumok összegyüjtése és ontológiai formába történő öntése, valamint a képzési és kimeneti követelményeken alapuló szakmastruktúra ontológiai megközelítésben való megvalósítása. 
- Illeszkedésvizsgálat: a két ontológia illeszkedésének a vizsgálata.

- Integráció: a kapott eredmények értékelése, a felsőoktatást érintő közigazgatási döntés-előkészítési folyamatba történő beilleszthetőségi vizsgálata.

\section{I.4. A kutatás módszertana}

A hipotézisek bizonyitását segitő kutatási módszertan megalapozásához először Babbie (1996) alapján a kutatás és az elmélet közötti kapcsolatot teremtő induktív, illetve deduktív gondolkodást, majd Balaton és Dobák (1991) ajánlásának szellemében a kvalitatív és kvantitatív metodológiát mutatom be. Az induktív gondolkodás egy megfigyelés-sorozatból indul ki és egy olyan összefüggés felé halad, amely bizonyos fokig rendet teremt az adott esetek között. Azaz a sajátos esetekböl kíván egy általános összefüggést meghatározni, amiről a felfedezés nem feltétlenül mondja meg, hogy miért áll fenn, csak annyit mond, hogy fennáll.

A deduktív gondolkodás ezzel szemben logikailag vagy elméletileg feltételezett öszszefüggést kíván megfigyelésekkel ellenőrizni. Azaz az általánostól halad a specifikus felé.

A kvalitativ kutatás a világ megfigyelését célzó magyarázó, naturalisztikus jellegü megközelítés. A kutatást végző személyek a dolgokat a természetes formájukban tanulmányozzák, valamint azzal az értelemmel ruházzák fel, interpretálják a jelenséget, amilyen jelentéseket az emberek adnak nekik. A kvalitatív kutatás a világ esettanulmányok, interjúk, személyes tapasztalatok stb. formájába történő transzformációja (Denzin és Lincoln, 2000).

A kvantitativ kutatás ezzel szemben nagy mennyiségủ adatok elemzéséhez kapcsolódó statisztikai eljárásokra épít. Az ilyen technikák használata lehetővé teszi hipotézisek reprezentatív mintával való tesztelését (Füstös et al., 1986).

A kutatás célja egy olyan rendszer fejlesztése, amely kapcsolatot kíván létesíteni a munkaeröpiac két oldala között a képzettség tekintetében. Mivel ennek érdekében az oldalakon fellelhető kompetencia-tartalmakat a valós mivoltukban kívánja szemlélni, és összefüggések feltárására törekszik, ezért kvalitatív technikák használatát indokolja. 
A kutatás nem illeszkedik bele a társadalomtudományi kutatások világába, ugyanis nem célja az emberek közötti kölcsönhatásokat magyarázó szabályszerüségek, összefüggésrendszerek feltárása (Babbie, 2001:4).

Sokkal inkább egy rendszer fejlesztésével kívánja ellenőrizni a koncepció helyességét, azaz azt, hogy a térben és időben strukturált munkaerő-piaci igényeknek kompetencia alapon megfelel-e az adott képzés. Ezért a kutatás az inkrementális rendszerfejlesztési módszertant (Sommerville, 2007 pp. 73) követi, amelyben a hipotézisek oly módon kapcsolódnak a fázisokhoz, hogy az adott inkremenssel támasztott követelményeket képviselik. Az egyes fázisok végtermékei alapján lehet vizsgálni a hipotézisek helyességét.

\section{I.4. 1. A kutatás hipotézisei}

H1. Meta-modellek segítségével kínálati oldalon a képzési és kimeneti kompetenciákból leképezhető a szakmastruktúra (térben, időben strukturálva), míg keresleti oldalon a meghirdetett állásokhoz kapcsolódó munkakört (FEOR) leíró kompetenciákból leképezhető a foglalkozási struktúra (szintén térben és időben strukturálva).

Mivel az ontológiák valamilyen tárgyterületre vonatkozó konszenzusos megállapodás alapján jönnek létre, valamint a fogalomalkotás formalizálására hivatottak, ezért a szakmai és a foglalkozási oldalon fellelhető dokumentumokból - a dinamikus feldolgozást biztosító internetes állásajánlatokból, valamint a Gazdaságinformatikus BSc kompetencia-tartalmait leíró forrásokból - egy-egy jól definiált, konzisztens modellt - a foglalkozási-, illetve szakmastruktúrát - lehet velük létrehozni. Azonban az összehasonlítási célkitüzés miatt érdemes ezekre úgy tekinteni, mint egy-egy általános meta-modell specializációira, aminek a kialakítására a IV.1.2. fejezetben kerül sor. Az időben való strukturálásuk alatt a megadott időpillanatokban (pl. havonta, negyedévente) való megjelenésüket, míg a térbeli strukturálás alatt a különböző földrajzi régióknak (pl. megyéknek, országoknak stb.) a reprezentációját értem.

A hipotézis igazolásához egy olyan rendszerre van szükség, amely a változásokat nagyobb gyakorissággal követő dokumentumokból kinyert szövegekből automatikus, vagy fél-automatikus módon, a meta-modellre építve felépíti a foglalkozási struktúrát, valamint képes a dokumentumokban bekövetkező változások alapján frissíteni is azt. Mindemellett implementálhatóvá teszi a lassan változó szakmastruktúrát is. Az időbeli és térbeli strukturálás annak alapján válik mérhetővé, hogy hogyan tudja tük- 
rözni a kompetenciák adott helyen, adott időben való megjelenését, illetve azok időben való megváltozását. A rendszer használhatóságát mutatja annak az értékelése, hogy mennyire automatikusan fér hozzá a dokumentumokhoz, illetve mennyire dinamikusan képes a dokumentum-feldolgozásra, a változáskezelésre, azaz milyen mértékủ emberi beavatkozást igényel.

Amennyiben sikerül egy olyan rendszert fejleszteni, amely tetszőleges képzésekre és a kapcsolódó munkakörökre vonatkozóan testreszabható, illetve a létrejött struktúrák az összehasonlítást előkészítve megfelelően tükrözik a munkaerő-piaci igényeket, valamint a képzés tartalmi elemeit a hipotézis elfogadásra kerül.

H2. Létezik olyan ontológiai alapú informatikai megoldás, amely segítségével a szakma- és a foglalkozási struktúra közötti egyezőségek és különbözőségek tételesen feltárhatóak.

A kutatási célként kitüzött megfelelőségi vizsgálat középpontjában a szakmastruktúra foglalkozási struktúrához való illeszkedésének a tanulmányozása áll. Az ontológiai alapú megközelítés használatát indokolja egyrészről a ráépülő illeszkedésvizsgálat átfogó szakirodalma, valamint az, hogy ez egy olyan modellezési eszköz, amely lehetővé teszi a fogalmak páronkénti összehasonlítását, ezzel együtt az egyezőségük, vagy különbözőségük tételes feltárását.

A hipotézis igazolásához olyan eszközre (lsd. IV.2 fejezet) van szükség, amely az ontológiai struktúrákra építve a fogalmakat a megfelelő kontextusban értelmezve hasonlítja össze és egy erre vonatkozó jelentést ad. A jelentés a további fejlesztések során akkor használható fel, ha a lehető legpontosabb találatokat adja meg. Így itt érdemes mérni, hogy a kapott találatok hogyan viszonyulnak az emberi összekapcsolás eredményeként született találatokhoz.

A két hipotézis igazolási folyamata során deduktívan az általános modell, illetve az ontológiai illeszkedésre vonatkozó összefüggések valós környezetben történő alkalmazására került sor.

H3. A szakma- és a foglalkozási struktúra közötti egyezőségeket és különbözőségeket feltáró rendszer hasznos eleme a felsőoktatási keretszámokat érintő döntéselőkészítési folyamatnak.

A kutatás során kifejlesztett rendszer hasznossága abban mérhető, hogy összeintegrálható-e a korábban említett kormányzati döntés-elökészítési folyamattal. A hipoté- 
zis bizonyításaként a rendszer által kapott összefüggéseket akarjuk általános környezetben alkalmazni, ezért itt induktív gondolkodásmódra van szükség.

\section{I.5. A kutatás jelentősége, hasznai}

Napjainkban a felsőoktatási képzési kínálat átalakítására irányuló kormányzati döntések vannak folyamatban. Bár az európai felsőoktatási térségből származó irányelvek kompetencia alapon kívánják a képzések tartalmát strukturálni, valamint a munkaeröpiac keresleti oldalán is olyan tendenciák tapasztalhatók, amely a munkaköröket ilyen alapra helyezve kívánják leírni, mégis a kormányzati döntések inkább más elgondolások alapján születnek. Ha figyelembe vesszük azt, hogy mind a szakmastruktúra, mind a foglalkozási struktúra kialakulását eltérő döntési szituációk befolyásolják és mind a két struktúrának van egyfajta mozgási tere, akkor az ontológiai alapon működő rendszer jelentősége az eltérő nézőpontok közös alapra hozásában, valamint a változások nyomon követésében mérhető.

A kidolgozni kívánt rendszer csak egy prototípus, azonban segítségével letesztelhető, hogy informatikai úton feltárhatóak-e a munkaerőpiac keresleti, és kínálati oldalának képzettségre vonatkozó különbözöségei. Az esetleges továbbfejlesztése mindemellett lehetővé teszi a strukturális különbözőségek képzésenkénti tételes feltárását egy bizonyos fokú bizonytalansági tényező mellett.

A 2012 októberében elindított Med-Assess projekt (Adaptive Medical Profession Assessor) az OntoHR projektben kialakított dinamikus tanulási rendszer eredményeit kívánja alkalmazni a gyógyítási szektorban (Corvinno, 2012). A dolgozatban bemutatásra kerülő rendszer egyik előfutára volt az OntoHR-ben megvalósított Informácórendszer elemző munkakört a holland és olasz felsőoktatási intézmények képzési kínálatával összehasonlító rendszer (Kismihók, 2012). A kutatásomban létrehozott fejlesztések hozzájárulnak ahhoz, hogy egy, a változásokat már dinamikusan követő programot lehessen a Med-Assess rendszerébe integrálni.

A 2012. november végén útjára induló SMART (Skill MAtching for Regional development) projekt célja a munkaerő-piaci igényeknek megfelelő képzésekre épülő tanulási rendszer készítése. A tervek szerint a kutatásom során kifejlesztett rendszer, illetve annak továbbfejlesztése a részét fogja képezni a projektterméknek. A projekt a magas munkanélküliségi rátával rendelkező, ám mégis túlképzettséget mutató anda- 
lúziai régióban kíván hozzájárulni a munkaerőpiac két oldalának kiegyensúlyozásához (Anon, 2012 pp.24). Azaz a rendszer hasznosságát a jelenlegi felsőoktatási döntés-elökészitési folyamatokban nem tudjuk tesztelni, köszönhetöen az alkalmazott eljárásoknak, azonban más alkalmazói körben hozzá tud járulni a kapcsolódó döntések meghozatalához. Ezáltal olyan - akár új képzések is - létrejöhetnek, amelyek a változásokat nyomon tudják követni, átláthatóbbakká válnak, ezáltal versenyképesebbekké is.

\section{I.6. A dolgozat sajátosságai, felépítése}

A hipotézisek vizsgálatát egy rendszer fejlesztésével és annak értékelésével kívánom megtenni, amelynek kellően megalapozottnak kell lennie, mivel a rendszer egy hoszszú távú, sokakat érintő döntés előkészítését kívánja támogatni. Ezért a kompetencia alapú összehasonlítás létjogosultságára, előnyeire kíván rámutatni az II. fejezet azáltal, hogy a fogalomnak a munkaerőpiac egyes oldalán való használatát, valamint eltérő szemszögből történő definiálását mutatja be, valamint kitér az egyes, használatban lévő modellek kutatásban való elemzésére is. A fogalom más szemszögből történő kezelésének egységes platformra hozásához járul hozzá az ontológia módszertan azzal, hogy a világ objektumainak konszenzuson alapuló, egységes, formális, explicit leírására törekszik. Az ontológia fogalom bemutatására kerül sor a III. fejezetben. A IV. fejezet foglalkozik a rendszer fejlesztésével, amelyben minden egyes fázis az abban a szakaszban alkalmazható eszközök szakirodalmi áttekintésével, valamint kapcsolódó szempontok szerinti értékelésével kezdődik. Ezt követi az algoritmusok kiválasztott rendszerben történő implementációja, valamint az esetleges eszközök használatának a bemutatása. Az egyes fázisok végén a szakaszban kifejlesztett inkremens emberi feldolgozással szembeni értékelésére kerül sor. Az V. fejezet foglalkozik a rendszer felsőoktatási döntés-elökészitési folyamatba történő integrációjának lehetöségével. Ez a terület azért nyert külön fejezetet, mert nem annyira rendszerfejlesztési, mint inkább oktatáspolitikai kérdés. 


\section{Kompetencia - elméleti háttér}

\section{II.1. A kompetencia szerepe a munkaeröpiac keresleti oldalán}

A gyorsan változó üzleti környezet eredményeként a vállalatok olyan komplex problémákkal szembesülnek, amely gyors reagálást, esetlegesen a szervezeti struktúra megváltoztatását kívánja meg tőlük. Mindez egyéni szinten az emberek szellemi erőforrásainak menedzselését vonja maga után. Bár már a taylori időben is foglalkoztak az emberek jellemzőinek vizsgálatával, mégis az 1970-es évek kutatásai, köztük McClelland (1973) munkássága egy egészen új megközelítést hozott. Flanagan (1954) kritikus esemény technikája - az egyén egy adott szituációban való sikerességének, vagy kudarcának a viselkedésbeli okait beazonosító eljárások halmaza - rávilágított arra, hogy nem a munkafeladatokra kell helyezni a hangsúlyt, hanem azt kell vizsgálni, hogy mire képesek az emberek. Ez vezetett ahhoz, hogy McClelland a köztudatba hozta a kompetencia vizsgálatának fontosságát, valamint egy olyan munkakör-tervezési megközelítést, amely a feladatok felsorolása helyett, inkább a munkakörök egyéni személyiségbeli, viselkedésbeli, illetve tudásbeli jellemzőin, azaz kompetenciáin keresztüli definiálását alkalmazza. Ahogy Lawler (1994) bemutatta a kompetencia-alapú szemléletben szerveződő vállalatok esetében ez a munkakörök tervezésén kívül érinti még a kiválasztási folyamat, a képzési, valamint a bérezési rendszer megváltozását is. Ettől kezdve az egyre részletesebb munkaköri leírásokat felváltják a szervezet, illetve a szervezeti stratégia által igényelt egyéni kompetencialeírások. A munkafolyamatok elemzésénél a hangsúly a végrehajtáshoz szükséges képességek vizsgálatáról áttevődik a munkafolyamat hatékony elvégzéséhez kapcsolódó egyéni kompetenciák feltárására. Ebben a szemléletben jobban elötérbe kerül a motiváció, valamint az emberi önértékelés kérdése. A stabil munkakörök diszfunkcionálissá válnak, határaik elmosódnak.

A kiválasztási folyamat során már nem mindenhol az álláshoz legjobban illö jelölt megtalálása a cél, hanem egy olyan jelöltté, aki mindamellett, hogy a szükséges munkaspecifikus kompetenciákkal rendelkezik, jól illeszkedik a szervezet tanulási környezetébe, azaz el tudja sajátítani az általa igényelt ismereteket. Vagyis egy pozíció betöltésekor szükség van olyan indikátorokra, amelyek előrejelzik, hogy a szóba 
jöhető jelentkezők, vagy meglévő munkavállalók közül ki az, aki a jövőben a lehető legjobb teljesítményt tudja nyújtani az adott munkakörben. Több kutatás, illetve tanulmány (Ghiselli (1966), Mischel (1968), Spencer(1993)) is rávilágított arra, hogy a vizsgákkal, illetve tesztekkel mért tudás nem elég jó előrejelző tényező, rendszerekre van szükség. Ezek a rendszerek akkor hatékonyak, hogyha nemcsak feltérképezik az új jelentkezők, vagy meglévő munkavállalók kompetencia-hiányosságait, hanem kompetencia-fejlesztési lehetőségeket, azaz tanulási útvonalakat is kínálnak nekik. Hiszen a munkavállalók annak alapján kapnak bért, illetve építhetik a karrierjüket, hogy milyen kompetenciákkal rendelkeznek, illetve hogyan tudják ezeket hasznosítani egy adott időszak alatt. A kompetitív előnyöket generáló szervezeti képességek fejlesztéséért felelös egyéni képességek megszervezése mindamellett, hogy hatékonyabbá teszi a szervezet müködését, stratégiai jelentőséggel is bírhat (Schoonover et al., 2000), illetve jelentős szerepe lehet az utódlástervezésben (succession planning) (Egodigwe, 2006) is.

\section{II.2. A kompetencia szerepe a munkaeröpiac kínálati oldalán}

Az elmúlt évtizedekben az oktatási színtéren a tanár helyett a tanuló került a középpontba. Azaz a hagyományos tartalomra fókuszáló, procedurális megközelítést felváltotta a tanulási eredményekre (learning outcome) koncentráló oktatás (Derényi, 2009). Az Európai Képesítési Keretrendszer, a jelenlegi oktatási rendszert is érintő megfogalmazásában a tanulási eredmények ,arra vonatkozó állítások, hogy a tanuló személy mit tud, mit ért meg, és minek az elvégzésére képes a tanulási folyamat befejeztével" (Tót, 2009 pp.19). Azonban hogyha azt is figyelembe vesszük, hogy ez a fogalom milyen szerepet tölt be az oktatástervezésben, akkor már sokkal árnyaltabb képet kapunk. Gagné felfogásában ugyanis a képzések tervezése a célok, azaz a tanulási eredmények beazonosításával kezdődik, majd az ezekhez hozzájáruló mérhető tevékenységek végrehajtásáért felelős feladatelemzések, azaz a tanulási hierarchia kialakítására kerül sor. Ezért értelmezi úgy a tanulási eredményt, mint amelyek „lehetővé teszik a tanulási folyamat apránkénti megértését, aminek a segítségével tervezésre vonatkozó precíz követelmények vázolhatók fel” (Proitz, 2010 pp. 122. ).

A tanulási eredményekre, mint standardokra építő oktatás előnyei közé sorolható többek között az, hogy a képzések az érdekeltek számára áttekinthetőbbé válnak, az értékelésük, valamint egymáshoz való viszonyuk bemutathatóvá válik, illetve egy- 
szerübb lesz a tantárgyak, vagy programok céljainak, elérendő eredményeinek a megfogalmazása, vagy korábbi képesítések elismerése során az elért eredmények meghatározása (Derényi, 2009). A tanulási eredmények definiálása kompetenciaszemléletben történik. Azért megfelelő építőkövek ezek, mert „,képesek felölelni az elméleti és gyakorlati mesterségbeli tudás és nézetek egészét, segítségükkel eldönthető a képesítés szintje, kiderülnek a hallgató erős és gyenge pontjai, kideríthetjük, hogy milyen kurzusok, illetve milyen képzési feladatok juttathatják el a jelöltet a kompetenciák/sztenderdek teljesítéséhez" (Falus, 2006 pp.174).

Benjamin S. Bloom (1956) nevéhez füződik az első, a szemlélet megalapozásához vezető taxonómia. Eredeti célja a különböző képzések tesztelési eljárásainak, eredményeinek jobb összehasonlítása volt. Ugyanakkor a kidolgozott rendszer Bloom elképzelése alapján:

- a képzési célok tekintetében jó kommunikációs eszközként,

- azoknak alárendelt sokszínủ képzések kidolgozási iránymutatójaként,

- valamint az oktatási célok, értékelések, tevékenységek a tanegység, kurzus, tananyag szintjén való egymásnak történő megfeleltethetőségi vizsgálatának az alapjául is szolgálhatott.

Taxonómiájának hat fó kategóriája volt: Tudás, Megértés, Alkalmazás, Elemzés, Szintézis és Értékelés, amelyek további alkategóriákra bontódtak. Ezek a csoportok az egyszerütől a komplexig, a konkréttól az absztraktig voltak rendezve (Kratwohl, 2002).

Manapság már tanulási eredmények koncepcióban készülnek a nemzeti képesítési rendszerek. Ugyanis 2003-ban az Európai Felsőoktatási Térség számára olyan képesítési keretrendszer létrehozása mellett döntöttek, amely kompetencia alapon igyekszik biztosítani az országok felsőoktatási rendszereinek átláthatóságát, valamint a végzettségek összehasonlíthatóságát (BoWoGroup, 2005). Mindezzel párhuzamosan útnak induló Tuning projekt arra törekedett, hogy az általános és téma-specifikus kompetenciák referencia-pontjait megállapítsa az első és második ciklusban végző hallgatók számára a menedzsment tudomány, neveléstudomány, geológia, történelem, matematika, fizika és kémia területén (Tempus, 2006). Ezeket a nem kötelező referencia-pontokat a különböző felsőoktatási intézmények felhasználhatják tantervfejlesztés és értékelés során. Így a függetlenségük megtartása mellett a tanterv kidol- 
gozásánál létrejöhet egy közös nyelv. Eközben az Európai Unióban szakértők bevonásával megindultak "Az egész életen át tartó tanulás Európai Képesítési Keretrendszere" (EKKR, angolul European Qualifications Framework for Lifelong Learning, EQF) kidolgozásának munkálatai is. Ennek a folyamatnak az a célja, hogy ,a legkülönbözőbb nemzeti és ágazati képesítési rendszerek, illetve képesítési keretrendszerek közötti jobb átjárhatóság, átválthatóság és hordozhatóság megteremtése révén ösztönzőleg hasson az egész életen át tartó tanulásra, továbbá biztosítsa a tanuló és munkavállaló egyén Unión belüli jobb mobilitását” (EKKR, 2009 pp.1).

Az OECD országain belül életre hívott Deseco (Definition and Selection of Competencies) projekt célja azon kompetenciák beazonosítása, amely a felnőttek és gyerekek számára lehetővé teszi a felelősségteljes és sikeres életet a modern, demokratikus társadalomban, valamint a jelen és jövőbeli kihívásokkal szembeni megfelelésüket segíti elő. Ezért a kompetenciák azonosítására kívánnak kidolgozni egy olyan közös, széleskörü keretrendszert, amely biztosítja a kompetenciák pontosabb és megfelelőbb mérését, és az empirikus eredmények interpretációját (DeSeCo, 2005).

Ezek a kezdeményezések mindamellett, hogy összhangban állnak egymással, a kompetenciákat használják fel a célul tüzött átláthatóság, átjárhatóság, valamint mobilitás biztosítására.

Nem véletlen tehát, hogy a felsőoktatásról szóló 2005. évi CXXXIX. törvény szerint „a tantervet alap- és mesterképzésben a miniszter által kiadott képzési és kimeneti követelmények ${ }^{5}$ alapján, szakirányú továbbképzésben szabadon” készítheti el a felsőoktatási intézmény.

Azaz megállapíthatjuk, hogy a munkaerőpiac mindkét oldalán tapasztalhatóak olyan tendenciák, amely a kompetencia alapon történő összehasonlítás fontosságát hangsúlyozzák. Azonban egy ilyen alapon müködő rendszer kidolgozásakor hamar szembesülhetünk azzal, hogy nincs egységes definíció a kompetencia fogalmára, amely a terminusok inkonzisztens használatára, kulturális különbségekre, eltérő elméleti, episztemológiai alapokra, valamint a kompetencia használatának különféle céljára vezethető vissza (Falus, 2006) (Winterton et al., 2006).

\footnotetext{
${ }^{5}$ Azoknak az ismereteknek, jártasságoknak, készségeknek, képességeknek (kompetencia) összessége, amelyek megszerzése esetén az adott szakon a végzettségi szintet és szakképzettséget igazoló oklevél kiadható.(forrás: http://www.felvi.hu/felveteli/fogalomtar/!Fogalomtar/index.php?betu=K)
} 


\section{II.3. A kompetencia fogalma}

A fogalom gyökere az eredeti latin Compete szóban lelhető fel, amelynek a jelentése az, hogy valamire képes. Az angol szakirodalomban azonban a fogalom kettébontódik competence-re, és competency-re. Rowe (1995) szerint az első esetben inkább a kielégítően alkalmazott gyakorlati képességekre, és az elért teljesítmény standardokra helyeződik a hangsúly, míg a második esetben az a fontos, hogy milyen viselkedés vezet az aktiválásukhoz. Azaz a competence szó esetében a „Mire képes az ember?”, míg a competencynél a „Hogyan képes azt megvalósítani?” kérdésre keresik a választ. Az Európai Unióban a competence szó van használatban, a magyar közoktatásban is ezt használják a kulcskompetenciák tekintetében (Tót, 2009 ).

Azonban nemcsak a fogalom összetettsége, hanem a szerzők eltérő nézőpontjának, az érintett kontextus különbözősége miatt is számos definícióval találkozunk a szakirodalomban.

„A pszichológiai megközelítés szerint a kompetencia hasonlít a személyiség-, a képesség-, a motivációs vagy a tudásbeli jellemzőkre, amelyek mind viselkedésben nyilvánulnak meg, ugyanakkor azonban sokkal inkább ezek fölé rendelt fogalom, és magában foglalja ezeket" (Henczi-Zöllei 2007, pp.29).

A felsőoktatásról szóló 2005. évi CXXXIX. törvény részletesen bemutatja a mögöttes tartalmat, ugyanis úgy határozza meg a kompetenciát, mint „ismeretek, jártasságok, készségek, képességek összességét”. Az OECD szerint viszont több mint tudás és képességek, inkább „,pszichoszociális erőforrások (beleértve a tudás és az attitüdök) igénybevétele, valamint mozgósitása segítségével a komplex igényeknek való megfelelés képességét foglalja magában” (DeSeCo, 2005 pp.4).

A munka világában a kompetenciák valamilyen tevékenység elvégzése során jutnak érvényre, amelyet a következő definíciók is jól szemléltetnek:

Gegesi Kiss et al. (2004 pp.193) szerint „,a kompetencia a teljesítőképes tudást, a megszerzett tudásnak és a meglevő személyes adottságoknak-készségeknek egy adott, konkrét környezetben való alkalmazási képességét jelenti."

Kraiciné (Henczi-Zöllei 2007, pp.18) is olyan dinamikus jelenségnek tekinti a kompetenciát amely "az oktatás, a képzés során megszerzett tudás, a szakmai és személyes tapasztalatok együttesét jelenti, ezáltal meghatározott funkció teljesítésére való 
alkalmasságot, valamint a megvalósulást szolgáló motívum- és képességrendszert" érthetünk alatta.

R.E. Quinn megállapításában a kompetencia "egy bizonyos feladat vagy szerep teljesítéséhez szükséges tudás és képesség" (Szelestey 2005, pp.5).

Sokkal átfogóbb, a kompetencia tulajdonságait is felsoroló definíciót adott meg a HR-XML Konzorcium ${ }^{6}$. Az ő értelmezésükben a kompetencia „egy specifikus, beazonosítható, definiálható és mérhető tudás, képesség, készség és/vagy más előrehaladás-típusú jellemző (pl. attitüd. viselkedés, fizikai adottság), amely az emberi erőforrás birtokában van, és egy adott üzleti környezeten belüli tevékenység végrehajtásához kapcsolódóan releváns, vagy szükséges” (HR-XML Consortium, 2006).

Összegezve, tartalmilag a következő elemeket különböztethetjük meg: tudás, jártasság vagy tapasztalat, képesség-készség, és viselkedési (magatartásminták, viselkedésjegyek stb.), motivációkat befolyásoló attitűdök (nézetek, kulturális beállítódás stb.). Mivel a személyes beállítódás lefedi az utolsó két kategóriát, így ezek az elemek összhangba kerülnek az angol szakirodalomban használt knowledge (tudás) skill $^{7}$ (képesség) - attitudes (személyes beállítódás) kategorizálással, illetve a gyakorlatban az angol anyanyelvi területeken használatos kognitív kompetencia, funkcionális kompetencia, és szociális kompetencia hármasával.

A tartalmi elemeket azonban nem függetleníthetjük attól az adott kontextustól, amelyben felhasználásra kerülnek, és amelyet generálhat egy feladat vagy egy tevékenység elvégzésére, illetve egy szerep vagy egy funkció betöltésére irányuló igény is. Mindemellett a kompetenciákat dinamikus felhasználási környezetben kell szemlélni, hiszen az alkalmazást igénylő szituáció, tevékenység, funkció vagy kontextus időben megváltozhat. Ez azt jelenti, hogy az adott kontextusban felmerülő szituáció interpretálása mellett rendelkezni kell a szituáció kezelésére irányuló lehetséges akciók repertoárjával, amin belül a relevánsakat képzés útján kell fejleszteni. Más szavakkal, egy munkakör betöltése esetén szükség van a sikerességhez, kimagasló telje-

\footnotetext{
${ }^{6}$ Egy független, non-profit, önkéntes alapon müködő szervezet, amely e-businessben is használható, humán-erőforráshoz kapcsolódó adatok automatikus cseréjét lehetővé tevő XML specifikációkból álló szabványkészlet kidolgozását tüzte ki célul. (HR-XML Consortium, 2006)

${ }^{7}$ Falus (2009 pp. 9) értelmezésében az angol skill a magyarban magában foglalja az egyszerủ műveletek automatikus végrehajtását jelentő gyakorlati készségeket, a bonyolultabb mủveletek részben automatizált végrehajtását jelentő jártasságokat, és egy átfogóbb tevékenység elvégzésére való alkalmasságot, a képességet. A magyar közoktatásban képességnek fordítják, de használják a gyakorlati készség elnevezést is (Tót, 2009 pp. 23).
} 
sítményhez kapcsolódó kompetenciák feltérképezésére, ezek revíziójára, valamint továbbfejlesztésüket elősegítő képzések biztosítására. Az ilyen típusú komplex rendszerek alapjául szolgálhatnak a kompetenciamodellek, illetve a képzéseket biztosító képesítési keretrendszerek.

\section{II.4. Kompetenciamodellek}

A kompetenciamodell a munkakörhöz köthető kompetenciaelvárások és az egyéni kompetenciakészlet egymásnak történő megfelelését szolgáló, a szervezetet, az egyént és a munkakört összekötő keretrendszer. (Henczi-Zöllei, 2007 pp.81)

Rowe (1995) szerint a menedzsmentben a következő tevékenységek során alkalmazzák a modelleket:

- kiválasztás esetén a cél az adott munkakör betöltéséhez szükséges „viselkedési adottságoknak" a meghatározása, valamint a jelentkezők birtokában lévő kompetenciák ebbe a körbe történő beilleszthetőségének a vizsgálata

- a képesség értékelés esetében arra használják, hogy felmérjék kompetens-e az illető az adott munkakörben

- a fejlesztés során a modell segítségével összegyüjtik az emberek erősségeit és gyengeségeit és kijelölik a fejlesztendő irányokat.

Boulter és munkatársai hat fázist határoztak meg egy adott munkakörhöz tartozó kompetenciamodell definiálására (Boulter et al, 1998):

1. Teljesítménykritérium meghatározása: az adott szerepben prezentálandó kimagasló teljesítmény eléréséhez kapcsolódó kritériumok.

2. Minta kiválasztása: az adatgyüjtési céllal mintavétel a szerepet betöltő emberek közül.

3. Adatgyüjtés: a sikerességhez vezető viselkedéshez kapcsolódó mintaadatok feltérképezése.

4. Adatelemzés: a kimagasló teljesítményt magyarázó kompetenciákra, valamint azoknak a kívánt teljesítmény érdekében való együttmüködésére vonatkozó hipotézisek készítése.

5. Validáció: az adatgyüjtés és adatelemzés eredményeinek igazolása. 
6. Alkalmazás: a kompetenciamodelleknek az igényelt emberi erőforrás tevékenységekben való alkalmazása.

Megkülönböztethetünk egész szervezetre, illetve egy specifikus területre vonatkozó modelleket. Jellemző azonban, hogy a vállalatok nem átfogó modelleket készítenek, hanem hozzáadott érték alapján - többnyire a vezetés területén - egy adott munkakörre, vagy szerepre fókuszálnak (Henczi-Zöllei, 2007 pp.82).

A továbbiakban bemutatásra kerülő modellek két csoportba sorolhatók. Egyik csoportot az általános, a másikat a menedzsment-specifikus modellek képezik. Az általános modellek közül a kompetenciamenedzsment területén használatos HLDmodellt, valamint az üzleti vezetők és oktatók együttmüködéséből született, az amerikai munkaerőpiacon használt ETA modellt mutatom be. A menedzsment-specifikus modellből a vezetés körében gyakran használatos Spencer-féle kompetenciaszótár, valamint az angol anyanyelvi területen iparági szabványnak számító Management Initiative Charter modell kerül bemutatásra.

\section{II.4.1. HLD kompetenciamodell}

A HLD modell azt hangsúlyozza, hogy az egyéneknek egy szakmai, illetve személyes - tudás, ismeret, készség és személyiségbeli vonásokat tartalmazó kompetenciakészletet kell létrehozni, illetve konkrét szituációban dinamizálni a saját magukra, illetve a környezetre irányuló céljaik megvalósítása érdekében. A kompetenciák öt klaszterbe vannak beosztva. Különbséget tesz annak alapján, hogy valamilyen tevékenység - munkavégzés, autonóm tanulás, alkalmazkodás, innováció - elvégzésére irányuló kompetenciáról, vagy ezek gyakorlásához nélkülözhetetlen elemröl (pl. logikus gondolkodás, együttmüködés stb.) van szó (Henczi, 2009 pp.14-15). Ennek megfelelően a modellben a releváns tevékenység alapjául szolgáló kulcs- és kognitív kompetenciák (általános kompetenciák), a feladatokkal és egyéni szükségletekkel, törekvésekkel adekvát szakmai kompetenciák, a munkahelyi és a társadalmi környezettel összefüggő szociális kompetenciák, a folyamatos önfejlesztéshez szükséges tanulási kompetenciák és a munkahelyi és társadalmi környezet fejlesztéséhez szükséges innovatív kompetenciák kapnak helyet. (Henczi-Zöllei, 2007 pp.91-92.). Ezek a kapcsolatát szemlélteti az 1. ábra. 


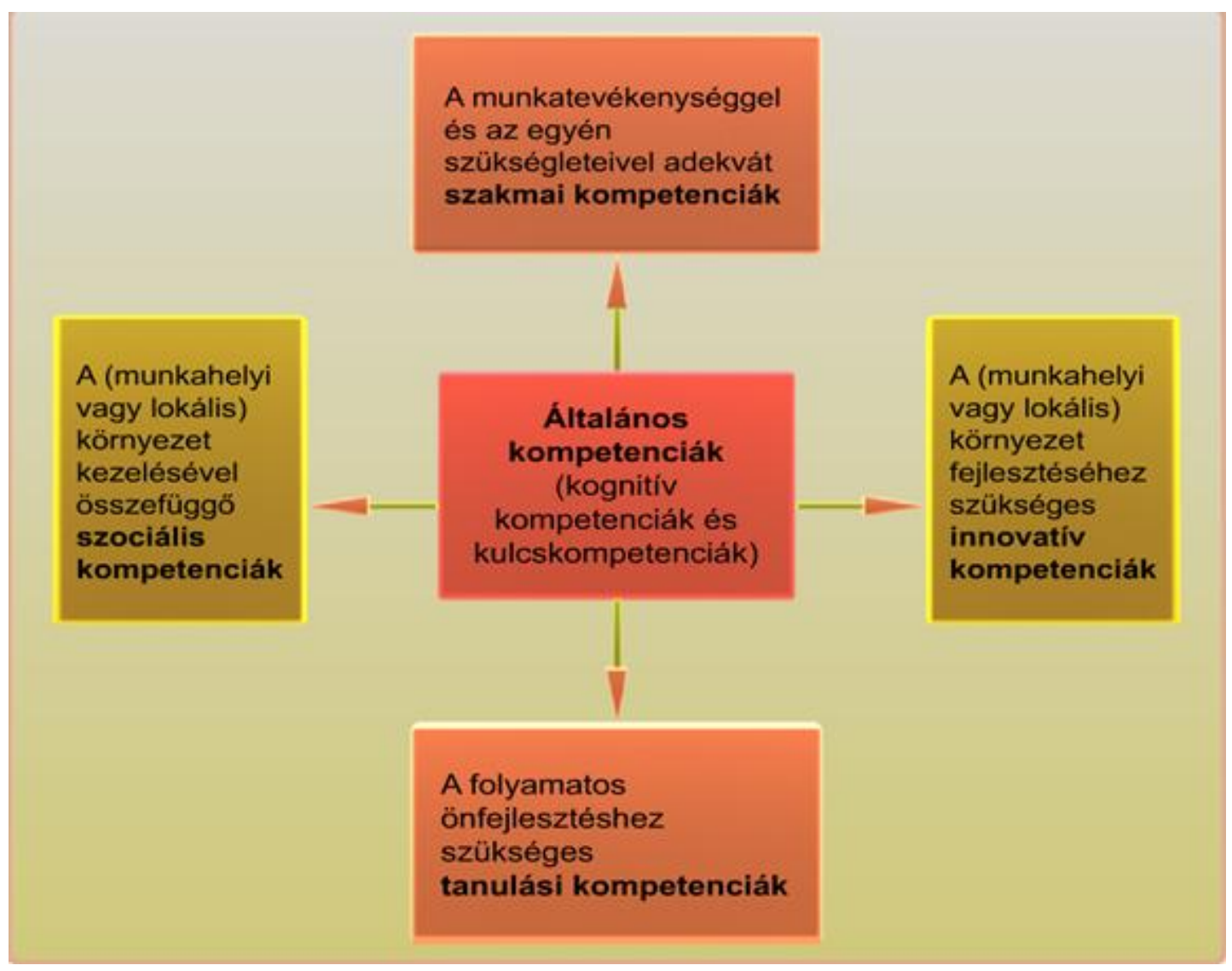

1. ábra HLD-féle kompetenciamodell (Henczi, 2009 pp.14)

A kompetenciacsoportok a tudás-készség-attitüd hármast magukban foglalják, amelyek szervezeti kontextusba kerülnek annak köszönhetően, az igényelt tevékenységek alapján lettek meghatározva. A modellben a specifikus kompetenciák általános kompetenciákra épülését lehet felfedezni.

\section{II.4.2. ETA (Employment and Training Administration) kompetencia- modell}

Az amerikai ETA (Employment and Training Administration) közigazgatási hivatal egyik programján belül az üzleti vezetők, oktatók és más érdekelt felek együttmüködése eredményként olyan érthető és áttekinthető iparági kompetencia-modellek jönnek létre, amelyek a gazdaságilag fontos iparágakban a munkahelyi sikerességhez vezető alap- és technikai képességeket és kompetenciákat tartalmazzák, illetve tananyag-fejlesztési erőforrásokat, bizonyítványokat, és kompetencia-értékelési teszteket biztosítanak.

Az általános keretrendszer (2. ábra) 9 szintből áll, amelyben a szintek egymásra épülnek. Az alsó három szinten lévő alapkompetenciák, - személyes hatékonyság 
kompetenciák, akadémiai kompetenciák, munkahelyi kompetenciák - általánosan, bármely iparágban, vagy foglalkozási körben alkalmazhatók. A következő két szinten már iparág-specifikus, azaz az iparági szektorokat, illetve teljes iparágat, érintő kompetenciákat találhatunk. Az utolsó négy szinten a foglalkozással kapcsolatos kompetenciák, azaz foglalkozás-specifikus tudásra, követelményekre vonatkozó, valamint technikai kompetenciák, illetve menedzsment kompetenciák lelhetők fel (Ennis, 2008).

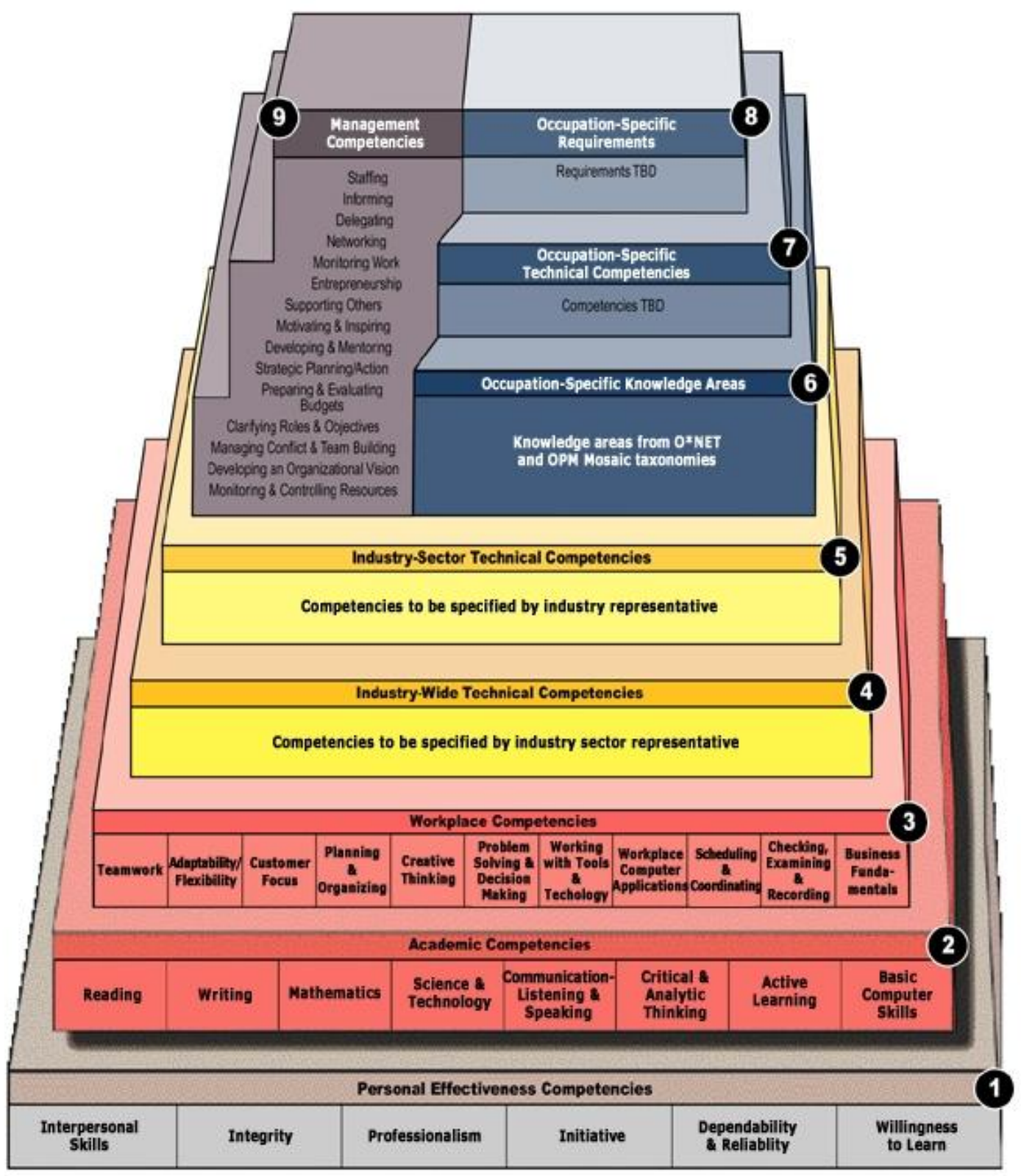

2. ábra ETA kompetenciamodell (Ennis, 2008 pp.7) 
Ebben a modellben is szakmai, illetve személyi kompetenciák jelennek meg, azonban a csoportok specifikusabb tevékenységek alapján lettek kialakítva, ezáltal több szinten kezelik a kompetenciák egymásra épülését.

\section{II.4.3. Spencer-féle kompetenciaszótár}

A Spencer-féle kompetenciaszótárat a vállalati kompetenciamodellek kidolgozására irányuló kutatásban alkalmazott, viselkedés alapú interjúkra épülve dolgozták ki. Minden kompetenciát definiáltak, illetve számos olyan indikátort rendeltek hozzá, amely annak gyakorlati alkalmazását méri (Irawan, 2011). A vezetői szerepkör ellátásához szükséges kompetenciákat a legfontosabb feladatok mentén - teljesítményre, minőségre törekvés, interperszonális kapcsolatok építése (mások támogatása, befolyásolása, fejlesztése, irányítása), ismeretek alkalmazása, valamint az önmagunk menedzselése terén - osztották csoportokba (lsd. 1. táblázat).

Ez a szótár a legelterjedtebb az előzetesen kialakított szótárakkal dolgozó vállalatok között (Bakacsi et al., 2005 pp. 144-145.).

\begin{tabular}{|c|c|}
\hline A „teljesítmény és cselekvés” kompetenciái & $\begin{array}{l}\text { teljesítményorientáció } \\
\text { rend kialakítása } \\
\text { minőségre és pontosságra törek- } \\
\text { vés } \\
\text { kezdeményezés } \\
\text { információkeresés }\end{array}$ \\
\hline A „támogatás és mások segítése” kompetenciái & $\begin{array}{l}\text { mások megértése } \\
\text { ügyfél-orientáció }\end{array}$ \\
\hline A „befolyásolás” kompetenciái & $\begin{array}{l}\text { befolyásolás } \\
\text { szervezeti tudatosság } \\
\text { kapcsolatépítés }\end{array}$ \\
\hline Vezetői kompetenciák & $\begin{array}{l}\text { mások fejlesztése } \\
\text { irányítás és asszertivitás } \\
\text { csapatmunka és együttmüködés } \\
\text { csapatvezetés }\end{array}$ \\
\hline Kognitív kompetenciák & analitikus gondolkodás \\
\hline
\end{tabular}




\begin{tabular}{|l|l|}
\hline & $\begin{array}{l}\text { fogalmi gondolkodás } \\
\text { szaktudás }\end{array}$ \\
\hline Személyes hatékonyság kompetenciái & önkontroll \\
önbizalom \\
rugalmasság \\
elkötelezettség a szervezet iránt
\end{tabular}

1. táblázat Spencer-féle kompetenciaszótár

Mivel itt menedzseri tevékenységek elvégzése kerül a középpontban, ezért a kompetenciák is erre a területre fókuszálnak. A tudás a kognitív kompetenciák között jelenik meg csak, a többi csoportban attitüdöket, képességeket és készségeket találunk.

\section{II.4.4. Management Charter Initiative}

A Management Charter Initiative (MCI ${ }^{8}$ által kidolgozott keretrendszer célja a menedzsment területén olyan szabványok biztosítása, amik kompetencia-alapúak, nemzeti szinten elfogadottak, a menedzseri teljesítménymérés alapjai lehetnek, valamint nemcsak a tudományos ismeretekre építenek, hanem a munkaerő-piaci igényekre is.

Két fő részből áll a Menedzsment Standardból (Management Standard), és a Személyes Kompetenciamodellből (Personal Competence Model), illetve a kapcsolódó tudásból és képességekből.

A Menedzsment Standardban határozták meg, hogy egy menedzsernek mit kell tudnia, valamint leírták azokat az elvárt eredményeket, amiket teljesítenie kell. Struktúrájában egy piramishoz hasonlít, a menedzser legfőbb céljából, azaz a szervezeti célok teljesítéséből, valamint folyamatos javulásból vezethetők le a müködési köréhez kapcsolódó kulcsszerepek (pl. müveletek menedzselése) betöltését elősegítő kompetenciaegységek (pl. szolgáltatási és termékműveletek fenntartása és javítása érdekében mozgásba hozott kompetenciák). Ezek további kompetenciaelemekre bonthatók (pl. azokra, amelyek a müveletek minőségi szabványoknak való megfelelésének a biztosítását teszik lehetővé). Hozzájuk kapcsolódóan vannak megadva a teljesítménykritériumok (pl. a müveletekhez szükséges összes ellátmány hozzáférhető legyen, és megfeleljen a szervezeti egység céljainak), valamint a kompetenciák alkal-

\footnotetext{
${ }^{8}$ A menedzsment területén az NVQ típusú képzések kidolgozásáért felelős vezető szervezet.
} 
mazási hatókörének keretet adó feltételek is (pl. a müveletek a menedzseri szintű felelősségi körbe tartozó tevékenységek).

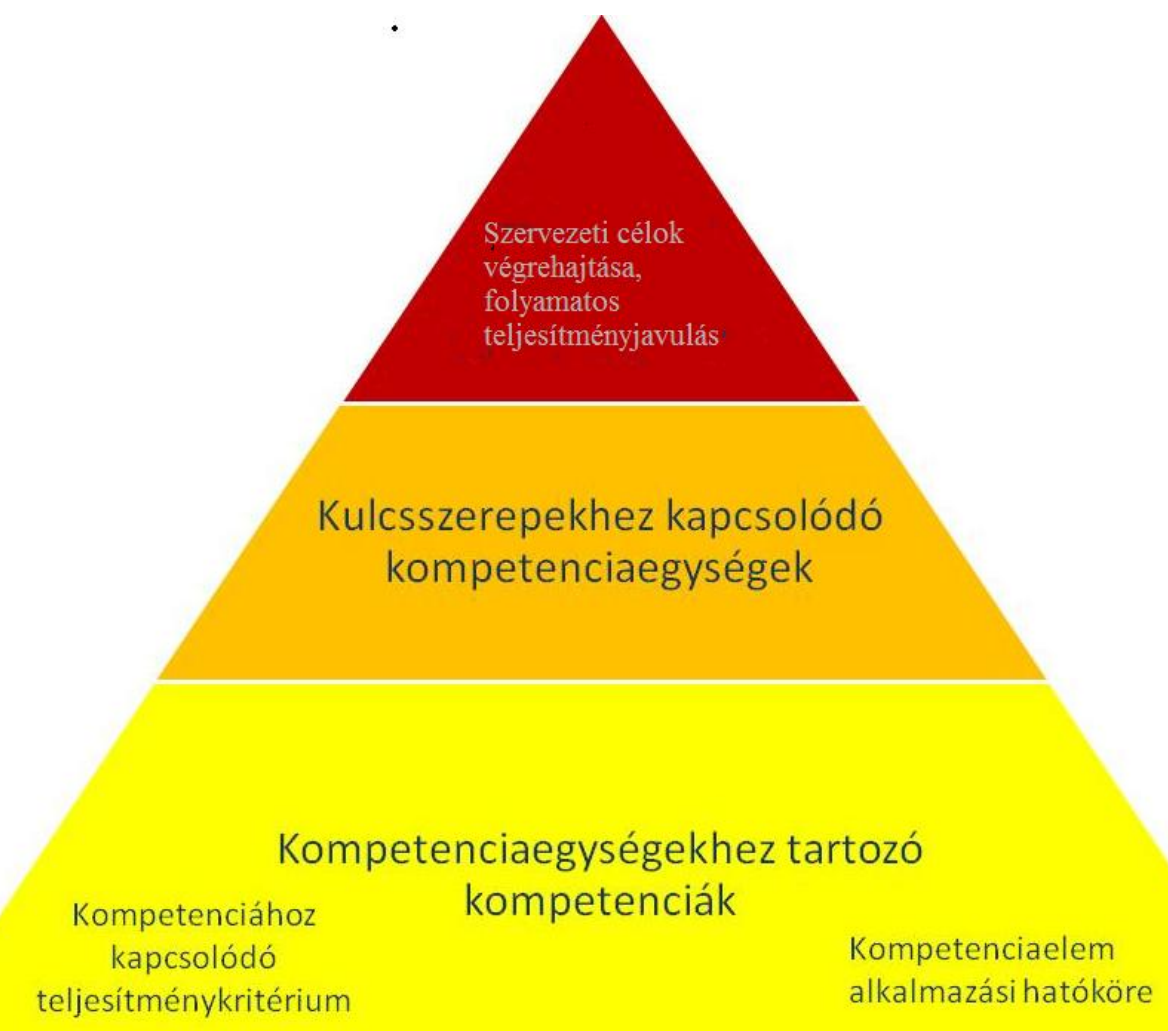

3. ábra MIC NVQ-n alapuló felépítése

Az értékelés annak alapján zajlik, hogy a menedzser az adott standardhoz tartozó teljesítménykritériumot hogyan teljesíti. A fejlesztés igényvezérelt, a menedzser irányítja ezt.

A Menedzsment Standardokhoz illesztették a Személyes Kompetencia Modellt, ami beazonosítja az eredmények végrehajtásáért felelős személyes kulcskompetenciákat, a tervezés, mások irányítása, önmagunk menedzselése, illetve az intellektualitás használata körében (Barker, 1993).

Megállapítható, hogy mindegyik modell szervezeti kontextusba helyezi a kompetenciákat, amelyek alkalmazási hatókörét az elvégzendő tevékenységek képezik. A menedzsment-specifikus kompetencia-modellekben azt is láthattuk, hogy a feladatok és a kapcsolódó kompetenciák szerepkörök alapján is csoportosíthatók. Mindemellett a tevékenységekhez illeszthetők teljesítménykritériumok, amelyeken keresztül lemérhető a kompetenciák konkrét szituációban való alkalmazása. Mivel a képzési oldalon nagyobb hangsúly esik a kompetenciák megszerzésére, mint a gyakorlatba törté- 
nő alkalmazásukra, ezért a képesítési keretrendszerek megismerése után kerül sor a modellek elsősorban tartalmi szempontból történő értékelésére.

\section{II.5. Képesítési keretrendszerek}

„A képesítési keret(rendszer) a képesítések meghatározott szempontok szerinti osztályozására és fejlesztésére szolgáló - általában politikai vagy stratégiai vízióval rendelkező - eszköz, amely - horizontálisan és vertikálisan - meghatározza a különböző képesítések közötti kapcsolatokat. A szempontok (pl. deskriptorok használata) tanulási eredmények adott szintjeire alkalmazhatóak. Az osztályozás alapján lehetnek szektorális, nemzeti és nemzetközi keretrendszerek.” (Temesi, 2011 pp.15)

Ahogyan korábban láttuk a tanulási eredményekre való fókuszálás - azaz arra, hogy a tanulási folyamat befejeztével a hallgató mit tud, mit ért meg, és minek az elvégzésére képes - paradigmaváltást eredményezett az oktatásban oly módon, hogy többek között a tantárgyak, programok céljainak, elérendő eredményeinek a megfogalmazása egyszerűbbé vált. A keretrendszerek így a használatukkal világosabb leírást adnak a képzésekről, a korábbi tartalmi megközelítéssel ellentétben egyértelmübben megadják a be-, és kilépési pontokat, megmutatják az egyes képzések közötti haladási irányokat, segítik a tanulókat új képzési formák felfedezésében. Mindezzel növelik az esélyegyenlőséget és elősegítik a nemzeten belüli, illetve a nemzetközi mobilitást.

Legelőször az angolszász területeken (Ausztrália, Új-Zéland, Egyesült Királyság) és Dél-Afrikában ismerték fel, hogy a tanulási eredményekre építő képesítési keretrendszer tudja a legjobban összekapcsolni a szakképzést a munkaerő-piaci igényekkel (Temesi, 2011).

\section{II.5.1. Nemzeti Szakmai Képesítés (National Vocational Qualifications)}

Az 1980-as években az Egyesült Királyságban a megnövekedett munkanélküliség, valamint a végzettek nem megfelelő képzettsége miatt az oktatás átalakítására volt szükség. Ezért a sokszínü képzési struktúra helyett egy egységes, nemzeti szabványokra építő képzési rendszer kidolgozását tűzték ki célul (Aitken, 1993). 
Azóta a korábbi ötszintű képesítési keretrendszert átalakították és felsőfokú tanulmányokat érintő szinttekkel bővítették ki. ${ }^{9}$

Nehéz arra bizonyítékot szerezni, hogy ezt a keretrendszert alkalmazó képzések magasabb szinten kvalifikálták volna-e a hallgatókat, azonban pl. az AAT (Association of Accounting Technicians) pénzügyi vezetők körében elvégzett tanulmánya szerint a vezetők 90\%-a úgy találta, hogy az NVQ bevezetése óta eltelt időben javult a könyvelési szakértők képzettsége. Mindemellett kritikaként fogalmazódott meg az NVQ-val szemben, hogy korábban ugyan lerögzítették, hogy a kompetencia szabványok kifejlesztése a munkáltatók bevonásával történjen, azok mégsem képviselik magukat jelentősen a fejlesztési folyamatban (Purcell, 2001).

\section{II.5.2. Európai Felsőoktatási Térség keretrendszere}

2005-ben a bergeni konferencián a felsőoktatásért felelős európai miniszterek egyetértettek az Európai Felsőoktatási Térség átfogó képesítési keretrendszerének adaptálásában. A rendszer áttekinthetőbbé teszi a nemzeti felsőoktatási képzési keretrendszerek, valamint azok képzései közötti kapcsolatokat, ezzel is hozzájárulva a célként kitűzött átláthatóság és mobilitás megvalósításához. 2010-re tették az ezzel kompatibilis nemzeti keretrendszerek kidolgozásának a határidejét. A keretrendszer a bologna folyamatban felvázolt első ${ }^{10}$, második, illetve harmadik ciklusú képzéseket tanulási eredmények, illetve kompetenciák használatával kívánja leírni, valamint útmutatást ad az első két ciklus közös kreditrendszerének kidolgozásához, használatához. A ciklusok szintleírására Dublin-deskriptorokat ajánl, amelyek minden egyes bolognai ciklus végét reprezentáló kimeneti képességekre, illetve tanulási eredményekre vonatkozó általános állításokat biztosítanak (Bologna Working Group, 2005).

\section{II.5.3. Európai Képesítési Keretrendszer}

Az EKKR (EQF) egy ún. meta-keretrendszer, amely tanulás eredmény alapú kimenetek alapján a formális és nem-formális tanulás keretei között megszerezhető képesítéseket - tartalmuktól függetlenül - nyolc hierarchikus, un. referencia szintbe sorolja (EKKR, 2012). Ezáltal egy standard alapot biztosít arra, hogy a nemzeti oktatási rendszerek keretei között keletkezett képesítéseket az EKKR-hez lehessen hasonlíta-

\footnotetext{
${ }^{9} \mathrm{http}: / /$ www.tvec.gov.lk/nvq/nvq_levels.htm

${ }^{10}$ Beleértve az első ciklushoz tartozó, vagy hozzá kapcsolódó rövidebb képzéseket is.
} 
ni, aminek a révén a különböző országok képzései is ténylegesen összehasonlíthatóvá válnak. Ehhez az objektív alapon történő összehasonlításhoz viszont szükséges, hogy az oktatás és képzés különböző szintjein hatékony és megbízható minőségbiztosítási rendszerek müködjenek.

A keretrendszer használatával ellenőrizhetővé válik, hogy a képzés valóban biztosítja-e az adott szintre definiált kompetenciákat.

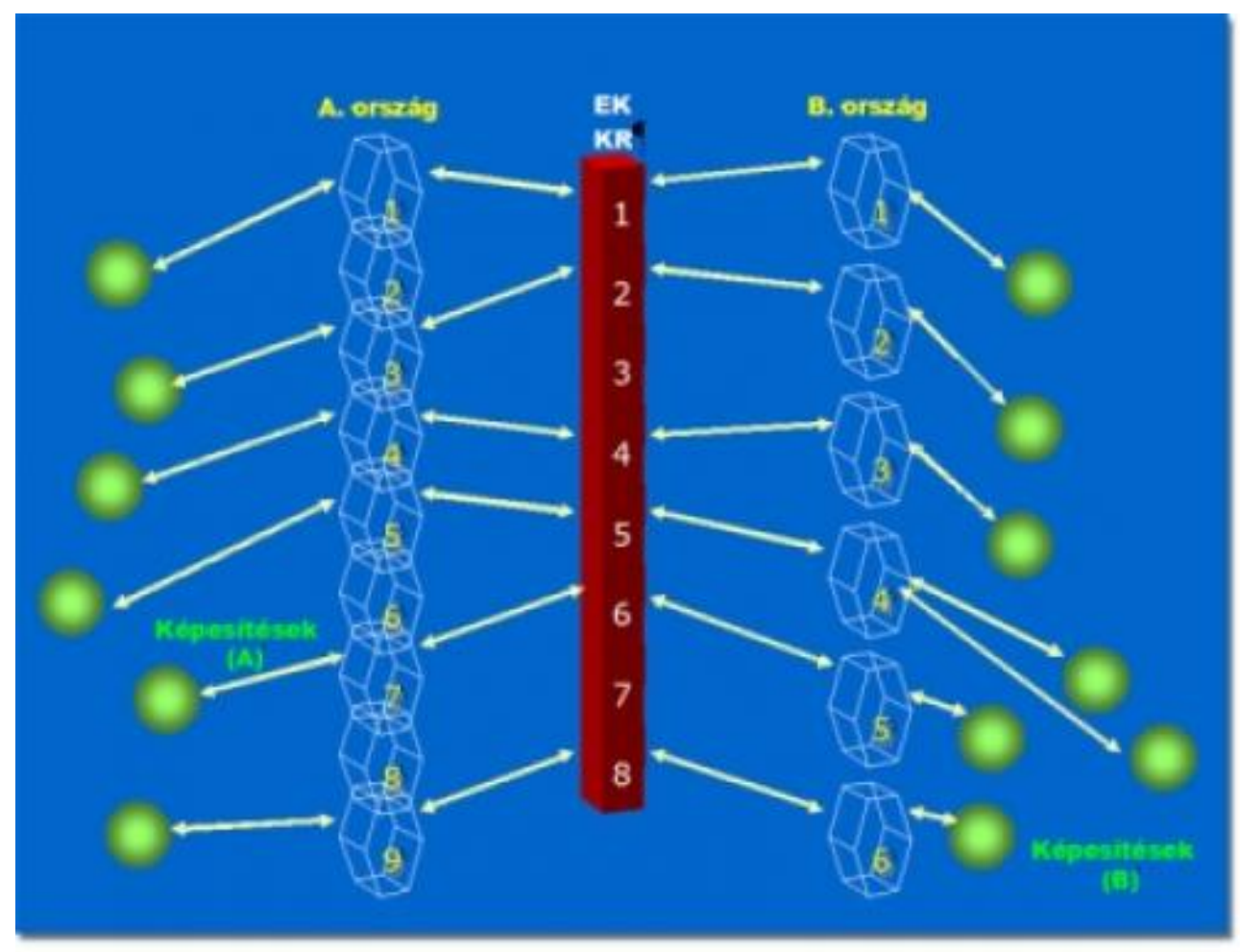

4. ábra Különböző képesítések összehasonlítása az EKKR alapján (Anon, 2009)

Az EKKR három fő elemből áll: a tanulási eredmények nyolc hierarchikus szintjéhez rendelt közös referenciapontokból/deskriptorokból, amiket az egyén (tanuló, munkavállaló, munkáltató) igényeihez igazodó európai eszköztárak támogatnak (pl. az európai kreditátváltás/beszámítási rendszerek). Továbbá tartalmazza azokat a közös elveket és eljárásokat is, amelyek a különböző szinteken müködő partnerek együttmüködését segítik elö pl. a minőségbiztosítás, nem formális és informális képzések beszámítása stb. terén (Temesi, 2011 pp. 21-27.)

Az Európai Parlament és Tanács 2008-as ajánlásában (EuParlCoun, 2008) 2010-re irányozta elő a nemzeti képesítési rendszerek EKKR-hez történő illeszthetőségének a vizsgálatát. Ezt oly módon javasolja elvégezni, hogy az egyes országoknak képesítési szintjeiket az EKKR referenciaszintjeihez kell viszonyítaniuk, és amennyiben szük- 
séges, akkor a tagállami joggal és gyakorlattal összhangban új nemzeti képesítési rendszert kell kifejleszteni. Magyarországon A Társadalmi Megújulás Operatív Program 4.1.3. számú, A felsőoktatási szolgáltatások rendszerszintủ fejlesztése című projektjén belül került kifejlesztésre az Országos Képesítési Keretrendszer (Támop, 2009).

\section{II.5.4. Országos Képesítési Keretrendszer (OKKR)}

A rendszer kidolgozásakor a munkacsoport az ajánlást követve az EKKR-t tekintette példának és viszonyítási alapnak, mindamellett, hogy figyelembe vette a hazai képzési gyakorlatot is. Így egy „,szektor-semleges” rendszert fejlesztett ki, amely megpróbálja egységesen kezelni az egyes oktatási területeket (közoktatás, szakoktatás és felsőoktatás), valamint azonos deskriptorokat használva egységes, általánosan érvényes rendszerbe foglalni a képesítési követelményeket.

A már meglévő képzések EKKR-nek való megfeleltethetősége során szükség van az EKKR - országos képesítési rendszer - regionális és egyes szektorokat érintő képesítési rendszer - szakmai képzések képesitési és kimeneti követelményei tengelyen az általánostól a konkrét felé haladva a szomszédos elemek egymáshoz való illeszthetöségének vizsgálatára. Azzal, hogy az OKKR jelentös mértékben igazodik az EKKRhez, a hazai képzések ugyan könnyen besorolhatóvá válnak az európai rendszerbe, de a képzési szintek és struktúra megfelelését az országos és az ágazati szinten kell majd elvégezni. Ez utóbbiaknak így megfelelően felépített hídnak kell lenniük a tengely két végpontja között.

Az Országos Képesítési Keretrendszer tehát az egész életen át tartó tanulást szem előtt tartva 8 hierarchikus, modulárisan egymásra építhető szintből áll, amelyek kompetencia alapú szintleírásokat tartalmaznak, ezzel lehetővé téve a kreditek alapján történő összehasonlítás mellett a tartalomra vonatkozó hasonlósági vizsgálatot is. A szintek között lévő különbségek áthidalása a folyamatos fejlődéssel valósitható meg, noha ez az elv csak a tudás kategóriájában valósul meg maradéktalanul. (Temesi, 2011 pp. 99-133.) 


\section{II.6. A kompetencia használhatósága a kutatásban}

A munkaerőpiac keresleti oldalán az a tény, hogy az USA-ban már a 20. század végén jelentős számú vállalat (pl. az American Company Association által megkérdezett 426 szervezet $80 \%$-a) helyezett folyamatba valamilyen kompetenciaalapú alkalmazást (Shippmann et al., 2000), illetve az európai országokban is elterjedt a kompetencia alapú munkakörelemzés, azt mutatja, hogy ez a megközelítés nagy gyakorlati hasznossággal bír a szervezetek számára.

Közben a munkaerőpiac kínálati oldalán nemcsak az Európai Képesítési Keretrendszer, de a bolognai folyamat keretein belül igényelt Európai Felsőoktatási Térség keretrendszere is a kompetencia alapú tanulási eredményekre összpontosító magyar oktatási-képzési rendszer meglétét igényli.

Az elmondottakból következik, hogy a két oldal összehasonlításának egyik megfelelő eszköze a kompetencia alapú megközelítés. Láttuk, hogy a fogalomnak számos definíciója van, amelyek azonban tartalmilag többnyire megegyeznek, attól függően, hogy a személyes beállítódást milyen határvonal mentén vágjuk el. Ezért az összehasonlítás alapjául a tudás-képesség-attitűd (TKA) hármast fogom használni.

Az oktatási színtéren a vizsgálat tárgyát képező Gazdaságinformatikus BSc képzés képzési és kimeneti követelményei (lsd. 1. melléklet) 2005 óta nem változtak meg, ezért stabil összevetési alapot képeztek.

A munka világát érintő kompetenciamodellek használhatóságának vizsgálatakor azt vettem figyelembe, hogy milyen mértékben ábrázolják a kompetenciát a valós környezetében, és mennyire használhatóak azok a kutatás tárgyát képező IT munkakörre vonatkozóan. Az óvatosságot az is magyarázta, hogy a tartalmi elemek a kompetencia felmerülését szolgáló kontextustól, szituációtól nem függetlenek. Tehát megnéztem, hogy mennyire szigorú határok között részletezik az összehasonlítás alapjául szolgáló kompetenciaelemeket, ábrázolják-e a kompetenciák egymásra épülését, a munkakörrel való kapcsolódási pontokat, illetve van-e valamilyen kapcsolatuk a képzési oldallal. A vizsgálat eredményét az alábbi táblázat tartalmazza. 


\begin{tabular}{|c|c|c|}
\hline & HL D-féle modell & ETA modell \\
\hline Kompetenciaelemek & $\begin{array}{l}\text { benne van a TKA } \\
\text { hármas, csak nem } \\
\text { ilyen szigorú ka- } \\
\text { tegóriában }\end{array}$ & $\begin{array}{l}\text { az egyes szinteken megjelenik a TKA } \\
\text { hármas }\end{array}$ \\
\hline $\begin{array}{l}\text { Kompetenciák } \\
\text { egymásra épülése }\end{array}$ & $\begin{array}{l}\text { az általánosra } \\
\text { épül a munka- } \\
\text { hely-, személy- } \\
\text { specifikus kom- } \\
\text { petencia }\end{array}$ & $\begin{array}{l}\text { általánosra ráépül az iparág-specifikus, } \\
\text { majd a munkakörrel kapcsolatba hozható } \\
\text { kompetenciák }\end{array}$ \\
\hline $\begin{array}{l}\text { Munkakörrel való } \\
\text { kapcsolat }\end{array}$ & $\begin{array}{l}\text { általánosan al- } \\
\text { kalmazható, nincs } \\
\text { utalás a munka- } \\
\text { kör nevére }\end{array}$ & $\begin{array}{l}\text { általánosan alkalmazható, a menedzsmen- } \\
\text { ten kívül nincs utalás a munkakör nevére, } \\
\text { de látható, hogy mely iparágból való }\end{array}$ \\
\hline $\begin{array}{l}\text { Képzési oldallal } \\
\text { való kapcsolat }\end{array}$ & $\begin{array}{l}\text { magyar szakkép- } \\
\text { zésre alkalmazták }\end{array}$ & oktatókkal együtt fejlesztették \\
\hline
\end{tabular}

\begin{tabular}{|l|l|l|}
\hline & Spencer-féle kompetenciaszótár & \multicolumn{1}{|c|}{ MIC } \\
\hline Kompetenciaelemek & a tudásra nem helyez hangsúlyt & benne van a TKA hármas \\
\hline $\begin{array}{l}\text { Kompetenciák egy- épülése } \\
\text { nincs }\end{array}$ & $\begin{array}{l}\text { a fastruktúra által adott hie- } \\
\text { rarchiában jelen van az } \\
\text { egymásra épülés }\end{array}$ \\
\hline $\begin{array}{l}\text { Munkakörrel való } \\
\text { kapcsolat }\end{array}$ & menedzsment & menedzsment \\
\hline $\begin{array}{l}\text { Képzési oldallal va- } \\
\text { ló kapcsolat }\end{array}$ & vezetóképzés terén & $\begin{array}{l}\text { NVQ képzésekkel össz- } \\
\text { hangban van }\end{array}$ \\
\hline
\end{tabular}

2. táblázat A kompetenciamodellek összehasonlítási alapként való vizsgálata

A táblázatból jól látszik, hogy a munkaerőpiac keresleti, illetve kínálati oldalának összehasonlítását elősegítő, kompetenciára vonatkozó kritériumok egyik modell esetében sem teljesültek hiánytalanul. A négy modell közül a legjobban a MIC és az ETA modell teljesített, azonban az előzőt csak az IT menedzserek esetében tudjuk 
alkalmazni, míg az utóbbinál a kompetenciák a kontextus-függőség alapján épülnek egymásra, és nem annak megfelelően, hogy mely kompetencia előfeltétele egy másik kompetencia meglétének.

Mindezekből kitünik, hogy egy olyan modellre volt szükség, amely általánosan felvázolja a kompetenciák tartalmát és alkalmazási környezetüket, majd aktualizálódik az adott munkakörre vonatkozóan. Ennek kidolgozásához járult hozzá az ontológia alapú megközelítés. Mivel a kutatásom középpontjában a foglalkozási, illetve szakmai oldalon meghatározott kompetencia-elemek összevetése áll, ezért az ontológia témakör bemutatása során inkább arra helyeztem a hangsúlyt, hogy milyen módon tud egy közös alapot szolgáltatni az esetlegesen más világnézetből született kompetenciák leírására, valamint összehasonlítására. A dolgozat határait feszegetné az öszszes olyan szerző müvének a felsorolása, akik az ontológia témakörével foglalkoznak, ezért közülük az ontológia tárgykör teljes, széleskörü áttekintésével foglalkozó Handbook on Ontologies c. müvet (Staab, 2009), valamint a magyar nyelvü müvek közül a tárgykör építőköveinek részletes bemutatásával, illetve összehasonlításával foglalkozó Vas (2007), illetve Kö (2004) doktori értekezését emelném ki. 


\section{Ontológia alapú megközelítés}

Számos tudományterület - többek között tudásmenedzsment, orvostudomány, mesterséges intelligencia - foglalkozik ontológiák készítésével, használatával. A fogalom maga a filozófiából fejlődött ki, amit az utóbbi évtizedekben az ettől némileg eltérő aspektust követve a számítástudomány területén is adaptáltak. Jelentésbeli eltérésük miatt Guarino és Giaretta (1995) által használt jelölést követve megkülönböztetem a filozófiai értelemben vett Ontológiát, és a számítástudományi szemszögből meghatározott ontológiát.

\section{III.1. Az ontológia fogalma}

Az Ontológia fogalom először 1613-ban jelent meg Rudolf Göckel (Goclenius) Lexicon philosophicum-ában, illetve Jacob Lorhard (Lorhardus) Theatrum philosophicum-ában, azonban filozófusok a gyökereit egészen Arisztotelészig vezetik vissza (Smith, 2002), aki a valóság természetét és struktúráját vizsgálta a Metafizika címü müvében és a „létező, mint létező”-ként definiálta az Ontológiát. Azaz a tapasztalati kutatásokkal szemben, amely egy adott szemszögből vizsgálta a dolgokat, Arisztotelész önmaguk teljességében, szempontoktól, aktuális létformájuktól, létezésüktől függetlenül kívánta szemlélni a dolgok természetét és struktúráját (Guarino et al., 2009).

A számítástudományban ezzel szemben a legtöbbet idézett Gruber (1993) megfogalmazásában az ontológia nem más, mint a „fogalomalkotás explicit specifikációja”, ahol a szerző Genesereth és Nilsson (1987) alapján a konceptualizáláson nem mást ért, mint „a valamilyen célból reprezentálni kívánt világról való egyszerü, és absztrakt szemléletet”, azaz egy bizonyos érdeklödési területen feltételezhetően létező objektumokat, fogalmakat, más entitásokat és a köztük fennálló kapcsolatokat. Juhász és Takács (2006) szerint, amikor gondolkodunk, a fogalomalkotás folyamata alatt a világ konkrét tárgyaiból, vagy személyeiből valamilyen közös tulajdonság kiemelésével osztályokat, csoportokat képezünk, illetve a kategorizálás során a tárgyakat rendeljük a fogalmakhoz. 
Az egy fogalomhoz tartozó tulajdonságok két csoportba sorolhatók: a prototípusok adják a legjobb példányok leírását (pl. a madarak repülnek), míg az akár definícióval (pl. a madár szülei madarak) is alátámasztott, az osztályba tartozást meghatározó kritikus tulajdonságok (pl. gének) adják a fogalom magját. Kategorizálás során dönthetünk a magtulajdonságok, vagy a prototípus alapján történő osztályozásról is. A fogalmakat a természetük megértése után, összekapcsoljuk és különböző nyelvtani szabályszerüségeket követve kijelentésszerü gondolatokba kombináljuk. Két kijelentés egymásba történő beágyazása nagyon összetett gondolatok kialakítását teszi lehetővé. Következtetést végzünk abban az esetben, amikor úgy szervezzük gondolatmenetté a kijelentéseinket, hogy ebből az egyik tézist, vagy következményt reprezentál, míg a többi a tézis alátámasztóiként, vagyis a konklúzió premisszáiként szolgál. Ez a folyamat a propozícionális gondolkodás során zajlik le, szemben a vizuális képzetekre építő képzeti gondolkodással, illetve a mozdulatok végiggondolását végző motoros gondolkodással (Atkinson et al., 1996 pp. 249-254.).

A fogalomalkotás során a világ szemléletét adó nézőpontnak az érintett embercsoport közös megegyezésén kell alapulnia, különben az elkészített ontológia nem fogja elég valósághủen tükrözni a leképezni kívánt területet. Studer et. al. (1998 pp. 185) pontosította is Gruber definícióját, azaz úgy definiálta az ontológiát, mint: „a közös szemléletü (megosztott) fogalomalkotás formális, és explicit specifikációja”. Azaz követelményként fogalmazta meg egyrészről, hogy egy csoport által elfogadott, konszenzusos tudást kell tükröznie, másrészről pedig azt, hogy világosan kifejezett módon, expliciten kell definiálni a fogalmakat, illetve a használatukra vonatkozó megszorításokat. Annak alapján, hogy az ontológiát milyen kontextusban kívánjuk alkalmazni, illetve milyen módon formalizáljuk, beszélhetünk:

„egy adott témakör szókészletét felépitő alapkifejezések, relációk és olyan szabályok összességéről, melyek a kifejezések és relációk összekapcsolásával biztositják a szókészlet bövitési lehetöségeinek meghatározását” (Neches et al., 1991, p. 40.), vagy a világ egy részének egyedi objektumok, fogalmak, a köztük lévö kapcsolatok, tulajdonságok, attribútumok, megszoritások, függvények, és szabályok formájában reprezentált számítógépes modelljéröl (Huhn és Singh, 1997 pp. 1). Az ontológiák alkalmazási környezetükben való szemléletét tükrözi Corcho et al. (2003. p. 44.). meghatározása: „,az ontológiák a megegyezésen alapuló tudás általános és formális megragadá- 
sát, újrahasznositását, valamint alkalmazások és emberek különbözö csoportjai közötti megosztásának biztositását célozzák meg".

Alapvetően tehát az ontológiaalkotás folyamatában egy elméletet alkalmazunk arra nézve, hogy „milyen entitások létezhetnek egy értelmes személy tudatában” (Van Heijst et al., 1997 pp. 191), mégpedig oly módon, hogy egy konszenzusos világszemléletből kiindulva kívánjuk elvégezni egy „adott érdeklödési területen feltételezhetöen létezö objektumok, fogalmak, entitások, és a köztük fennálló kapcsolati rendszer" (Guarino et al., 2009 pp. 3) feltérképezését és specifikálását. (Itt jegyzem meg, hogy az ontológia-fogalom bővebb, mint a szintén ismeretek rendszerezéséért felelős taxonómia, ugyanis az ontológia a fogalmak és objektumok leírását is tartalmazza (Sántáné-Tóth, 2006)). Az ontológia fogalom algebrai definíciójával a IV.2.1.1 fejezet foglalkozik.

Az ontológiák Guarino (1995) megközelítésében általános, szakterület, feladat és alkalmazás független fogalmakat reprezentálhatnak magas szintủ ontológia formájában, vagy ezen alapulva valamely tevékenység, feladat, illetve szakterület fogalomkészletének a leírását adhatják meg, illetve e kettő egy konkrét alkalmazásra vonatkozó specializálását mutathatják be feladat-, szakterületi-, illetve alkalmazás ontológia képében.

Azonban még ha a felsőoktatási képzések a foglalkozási és az oktatási oldal közös egyetértésében kerülnek is kialakításra (ahogyan láttunk erre irányuló kezdeményezést a National Vocational Qualification esetében is), akkor is a képzési idő alatt beleértve a meghirdetéshez, felvételiztetéshez szükséges időt is - az eredetileg megfogalmazott képzési és kimeneti követelmények megváltozhatnak. Ennek bekövetkezésekor viszont már nem jellemző a két oldal közötti egyeztetés megteremtése. Ezért előfordulhat, hogy a két oldalon ugyanaz a kompetencia más szemléletből kiindulva, más kontextusba helyezve, más lényegi elemek kiemelésével kerül interpretálásra. Vagyis a kutatásom céljaként megfogalmazott összehasonlítás, ontológiaszemlélet alapján történő megvalósítása végett elöször is szükség volt a munkaerőpiac keresleti és kínálati oldalán fellelhető kompetenciatartalmak egy-egy ontológiai struktúrába történő formalizált leképezésére (formális specifikációjára), majd ezen ontológiák egymáshoz való illeszkedési vizsgálatának a végrehajtására. Ezek után került sor annak az elemzésére, hogy a jelenlegi felsőoktatást érintő döntés-előkészitési folyamatba hogyan illeszkedik be a kidolgozott rendszer. A tevékenységek alapjául szolgáló 
elmélet bemutatására, valamint a gyakorlati megvalósulás ismertetésére az 1. fejezetben felsorolt fejlesztési fázisokat követve került sor.

\section{Az informatikai rendszer fejlesztése}

Az I. fejezetben bemutatott első két hipotézis ${ }^{11}$ képezte a rendszerrel szembeni követelményeket, amik két egymásra épülő, azonban elkülönülten fejleszthető funkcióhalmazt határoztak meg. Ahogyan az 5. ábrából is látszik az inkrementális fejlesztés folyamata megfelelő alapot biztosított a rendszer fejlesztéséhez, ugyanis itt az inkrementációs lépések meghatározásában nagy szerepe volt annak, hogy „minden egyes inkrementáció a funkciók egy-egy újabb halmazát adja a már meglévőkhöz” (Sommerville, 2007 pp. 73). Azaz egy újabb iteráció elején az előző inkremens átadása során felmerült, valamint a felhasználók által megadott e szakaszt érintő követelmények kerülhettek beépítésre.

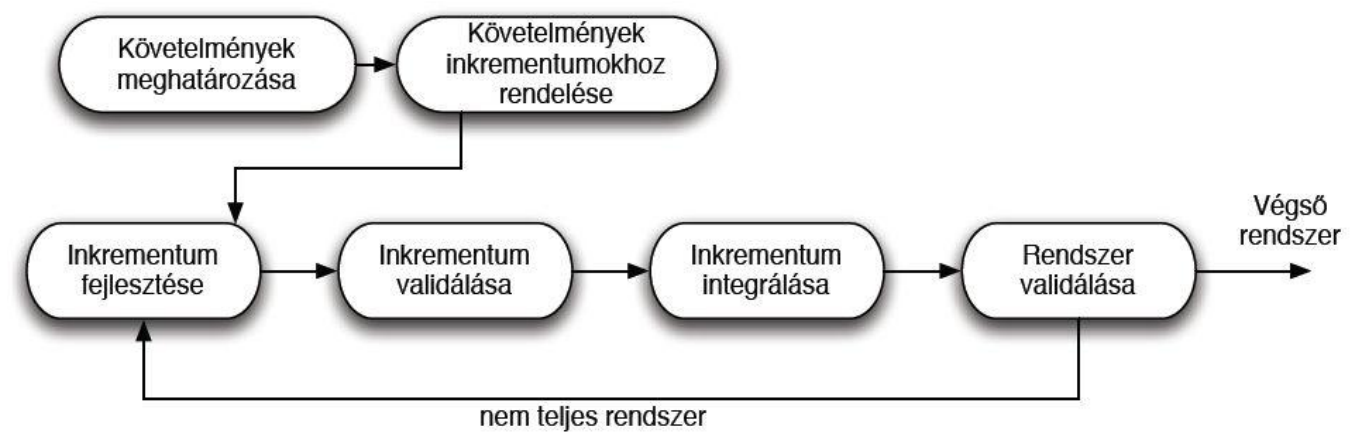

5. ábra Inkrementális fejlesztés folyamata ${ }^{12}$

Erőforrás hiányában ezen dolgozat keretén belül a teljes Gazdaságinformatikus szak implementációjára nem kerülhetett sor, ezért a fejleszteni kívánt rendszer egy prototípus.

A hipotézisek alapján a rendszerrel szemben támasztott követelmények a következők voltak:

- képes legyen a Profession.hu portál IT/Telekommunikáció kategóriájába eső internetes állásajánlatok automatikus letöltésére, valamint azokból egy ontológiai struktúra - a Munkaköri Leírás Ontológia - létrehozására, illetve az

\footnotetext{
${ }^{11}$ A harmadik hipotézis a koncepció más megközelítésekkel szembeni eredményesség mérésére szolgál.

${ }^{12}$ Forrás: http://www.excarta.hu/index.html\#slide0031.html
} 
előzetesen kialakított Képzési Kimeneti Követelmény Ontológia felvihető legyen a rendszerbe,

- a két ontológia Kompetencia osztályára vonatkozóan feltárhatóvá váljanak az egyezőségek és különbözőségek.

\section{1. A fejlesztés elsö fázisa: szakterületi ontológiák kialakítása}

Ebben a fázisban két szakterületi ontológia kialakítására került sor, amelyek alapját korábbi, tárgyterületet érintő meta-modellek módosított változatai adták.

Az oktatási oldalon a Gazdaságinformatikus BSc szakalapítási és egyéb, a szakot jól reprezentáló forrásokból kiszedett kompetenciák a Képzési Kimeneti Követelmény Ontológiába (KKKO) lettek leképezve. Míg a foglalkozási oldalon olyan ontológiára volt szükség, amely a korábban említett időszakos változásokat is tudja kezelni. Ezért itt a változásokat magukban hordozó, az automatikus feldolgozást garantáló internetes állásajánlatok alapján meghatározott munkaköri kompetenciák és azok kontextusa alapján, a Munkaköri Leírás Ontológia (MLO) került kidolgozásra. A szakterületi ontológiák formális specifikációját támogatta a megfelelő ontológia-leíró nyelv, módszertan, valamint fejlesztői környezet. Az ontológiafejlesztés során először a meta-modellek kerültek kialakításra, amelyek az adott tárgyterületre történő adaptáció során új elemekkel egészültek ki. Mivel itt a foglalkozási oldalon szöveges anyagból való feldolgozás történt, ezért az ontológiaépítés fél-automatikus megvalósításához szükség volt olyan algoritmus kidolgozására, amely félig, vagy rosszul strukturált szövegből is képes a meta-modell osztályai alá tartozó új osztályokat, valamint hozzájuk kapcsolódó egyedeket kinyerni. Ezen algoritmus alapjául szolgáló kifejezés-gyüjtemény kidolgozásához nyújtottak segítséget a különböző természetes nyelvi feldolgozó (NLP) technikák.

A következőkben így a szakterületi ontológia építését megalapozó kutatásokat, a kialakított meta-modelleket, a modellek implementációját elősegítő módszertant, nyelveket és fejlesztői környezeteket, valamint az implementációt mutatom be. Ezek után kerül sor az MLO meta-modelljének NLP eszközök segítségével történő kibővítésére, tudáselemmekel való kiterjesztésére, illetve a két modellben példányok létrehozására. A feladatot elvégző algoritmus értékelésére a szakasz végén kerül sor. 


\section{IV.1.1. Szakterületi ontológia fejlesztését megalapozó kutatások}

A szakterületi ontológiák kialakításához szükség volt egy-egy olyan meta-modellre, amelyeknek az adott területekre vonatkozó specializációja adta meg a keresett ontológiákat. Ebben a témakörben történő kutatások közül leginkább a kutatási célomhoz közel álló ontológiákat, azaz Draganidis és kollégái által kifejlesztett ontológia alapú kompetenciamenedzsment rendszert, Mochol és társai által létrehozott emberi erőforrás ontológiát, valamint a SAKE és az OntoHR projekt keretében kidolgozott ontológiát mutatom be.

Az athéni Nemzeti Müszaki Egyetemen Draganidis és kollégái (Draganidis és Mentzas, 2006) kidolgoztak egy olyan ontológia alapú kompetenciamenedzsment rendszert, amely az alkalmazottak (bővebben a szervezet) képességbeli hiányosságait kívánja feltárni, majd erre építve ajánl számukra egy tanulási útvonalat, illetve más emberi erőforrás funkciókat - utódlás-, karriertervezést, képzési igények elemzését, szervezeti tervezést - is támogat. A más rendszerekkel (tanulási, vagy emberi erőforrás) rendszerekkel való együttmüködést segíti elő a kifejlesztett Kompetencia Ontológia (6. ábra), amely osztályai az alkalmazottakat, projekteket, munkaköröket, szervezeti egységeket, kompetenciákat (skill), tanulási objektumokat, valamint ezek kapcsolatait írják le. A SkillLearnObj_Lvl osztály a kompetenciák és a tanulási objektumok közötti viszonyt határozza meg. A SkillRelated osztály felelös a munkavállalói, valamint a munkakör által igényelt kompetenciák közötti távolságok meghatározásáért. Hiányzó kompetencia esetén a megfelelő tanulási útvonalakat, vagy ennek hiányában a kapcsolódó kompetenciákhoz tartozó tanulási objektumokat ajánlja fel a rendszer. 


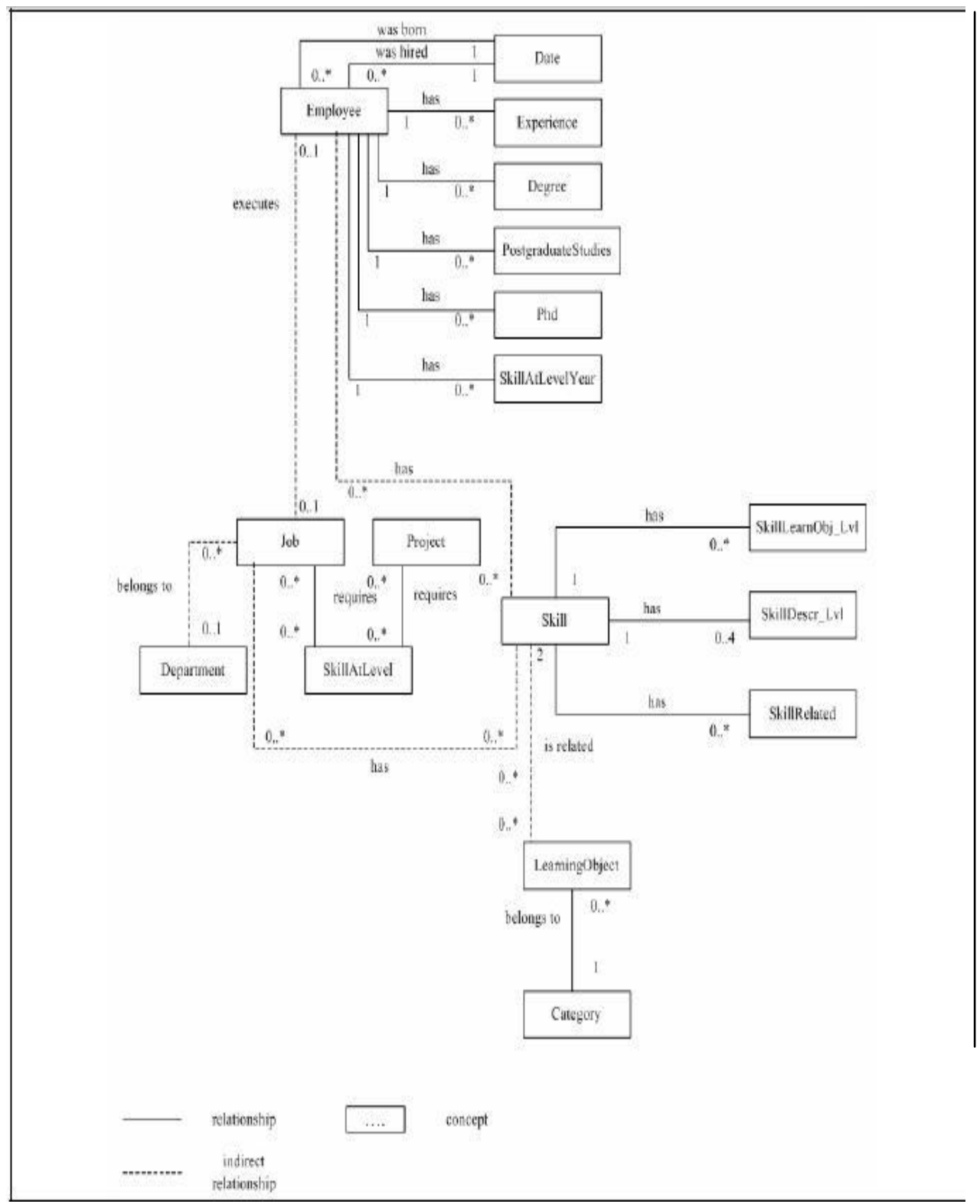

6. ábra Kompetencia Ontológia (Draganidis és Mentzas, 2006 pp.4)

Mochol és kollégái (Mochol et al., 2004) az Emberi Erőforrás Ontológiát (7. ábra) használták fel az álláshirdetés és a jelentkező profiljának az összehasonlítására. Az ontológiát az iparágat nemzetközi szinten specifikáló Iparág, a vállalatot reprezentáló Szervezet, a jelentkező személyes adatait leíró Személy, valamint a Kompetencia (Skill), Álláskereső, Álláshirdető alontológiákból építették össze. A Kompetencia ontológia tartalmazza a kompetenciákat reprezentáló fogalmakat, amelyeket akár a munkakör leírásánál, akár a jelentkező profiljának kialakításánál fel lehet használni. A profil, és a munkaköri követelmények között szemantikus hasonlósági értékek kiszámolásával kívánták a lehető legjobb összerendelést megadni. 


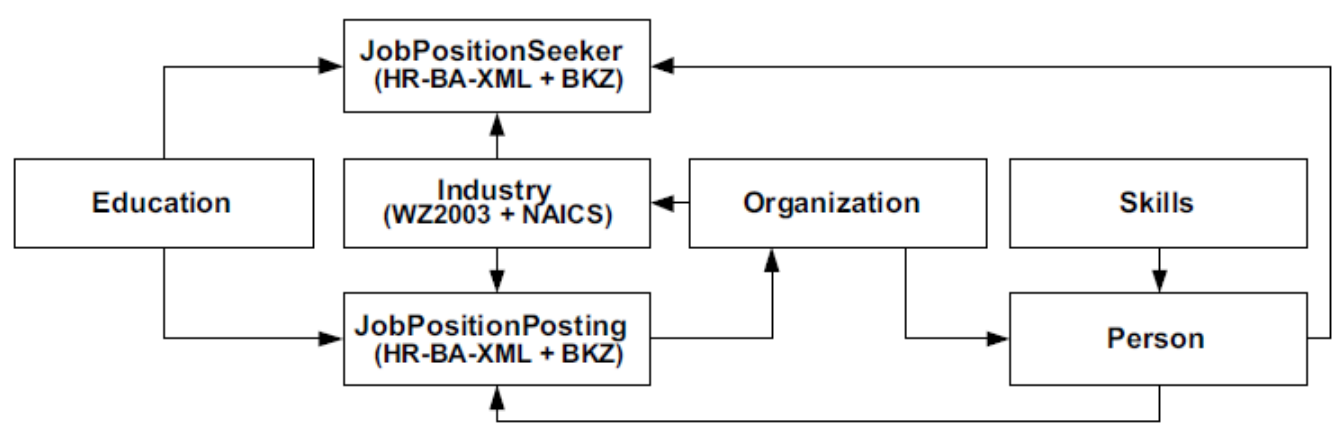

7. ábra HR ontológia felépítése (Mochol et al., 2004 pp.4)

A SAKE projekten belül került kidolgozásra a Felsőoktatási alapontológia (8. ábra), amely a kutatásom céljaként is megfogalmazott összehasonlitást hivatott támogatni. (Kö-Futó, 2008)

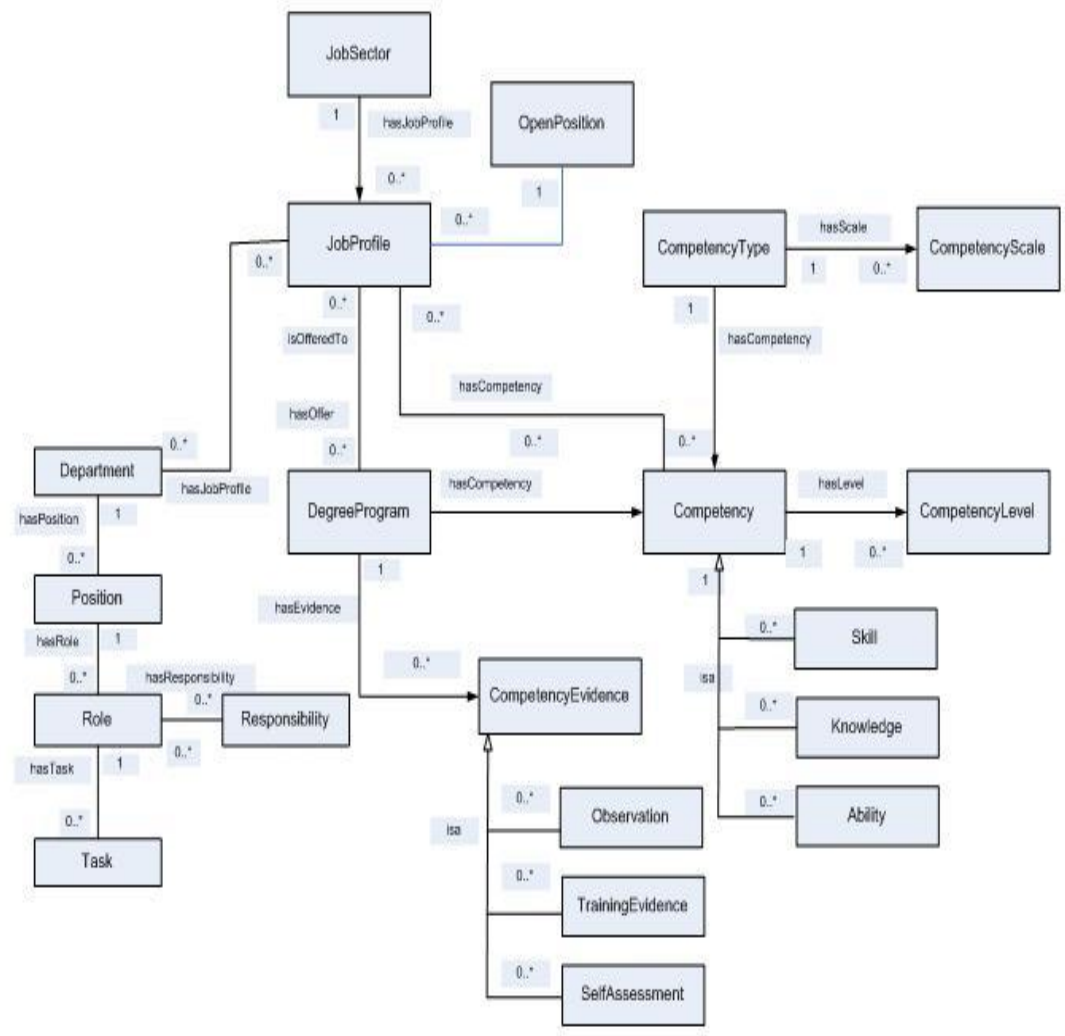

8. ábra Felsőoktatási alapontológia

A képzés DegreeProgram, valamint a szervezeti részleg Department osztályához tartozó, munkakört leíró Job Profile osztályok a Competency osztály kompetenciáinak a részhalmazát alkotják. A Competency alosztályai a Skill (képesség), Knowledge 
(Tudás), és Ability (készség) osztályok. A kompetenciának van a CompetencyLevel által reprezentált szintje, és a CompetencyType által bemutatott típusa.

Az OntoHR projekten belül az összehasonlítás alapját a Munkaköri Ontológia Modell képezi, ami az Oktatási Ontológia (Vas, 2007) módosított változata. Ez utóbbi feladatra való alkalmasságát mutatja, hogy a HEFOP-3.3.1-P.-2004-09-0093/1.0. „Tudásszintkiegyenlítő, rövid ciklusú e-Learning kurzusok kifejlesztése” projekt keretén belül kialakított rendszer alapjául szolgált (Gábor et al., 2008). A módosított változatban újdonságnak számít, hogy a kompetenciák mentális képességek (Mental Ability) meglétét igénylik (requires kapcsolat), illetve biztosítják is azokat (ensures kapcsolat), modulokba szervezhetők (Competency Modul), valamint előfeltételei egymásnak (prerequisite kapcsolat). Az ábra többi részét részletesen (Vas, 2007), valamint (Kismihók et al., 2012) mutatja be.

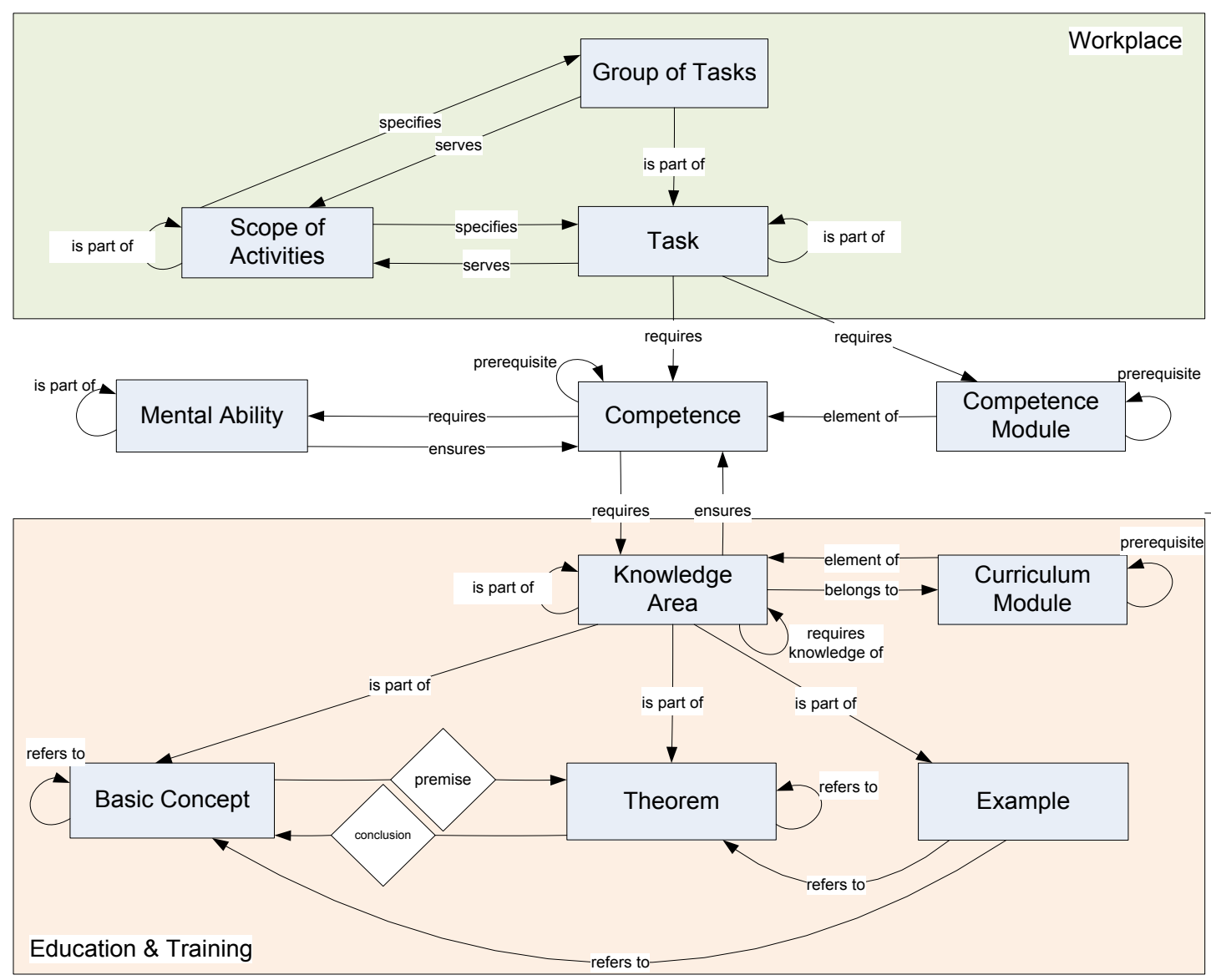

9. ábra Munkaköri Ontológia Modell felépítése

Mochol és Draganidis a jelentkezők, illetve az alkalmazottak kompetenciáinak az illeszkedését vizsgálta a munkaköri követelmények tükrében, ezért a kompetenciákat 
a szervezeti egységekből, munkakörből, valamint a személy, alkalmazott személyes tulajdonságaiból vezették le. A SAKE és az OntoHR projekt ezen túlmenően hiányzó, vagy plusz képzési és kimeneti kompetenciákat kívánt megadni. Ezért az oktatási oldalon a képzési programokhoz csatolták a kompetenciákat. Fontos, hogy egyik kutatásban sem valósult meg maradéktalanul az általános szakma-, illetve foglalkozási struktúra illeszkedésvizsgálata. Illetve a foglalkozási oldalon megkívánt, dinamikus változtatások kezelése sem. A SAKE-ban manuálisan lettek letöltve és kulcsszavazva (,betaggelve”) a dokumentumok, vagyis a feldolgozott munkakörök közel sem voltak teljeskörüek. Az OntoHR-ben pedig az Információrendszer elemző (Information System Analyst) munkakörhöz való illesztést vizsgáltuk, amelynek a kompetenciatartalmai már meglévő - az O*net szervezet és az EUQuaSIT projekt keretén belül kidolgozott - leírásokból lettek kinyerve. Mivel mindegyik ontológia az összehasonlítást a kompetenciák szintjén végezte el, ezért az empirikus kutatáshoz alkalmazni kívánt meta-modell megfelelő alapjául szolgáltak.

\section{IV.1.2. Kompetencia meta-modellek}

Az első hipotézis bizonyításaként megcélzott szakma-, illetve foglalkozási struktúra elkészítéséhez szükség volt olyan meta-modellekre, amelyek lehetővé tették a két oldal összehasonlíthatóságát. Ezeknek a következő követelményeket kellett tejesíteniük:

- térben és időben strukturálva kellett tartalmazniuk a munkaerőpiac keresleti oldalán felmerülő kompetencia igényeket, valamint a kínálati oldalon a képzések által biztosított kompetencia tartalmakat

- a kontextusba történő helyezése végett a kompetenciákat a szervezet által meghatározott világba kellett elhelyezni, illetve a felsőoktatásban folyó tudásátadást kellett reprezentálni vele.

A szervezeti oldal megteremtéséhez nyújtott nagy segítséget az első három ontológia modell, míg a felsőoktatási reprezentáció alapjául az utolsó ontológia szolgált. Ezen ontológiák összeolvadásából, valamint a követelmények beillesztéséből keletkeztek az alábbi meta-modellek: 


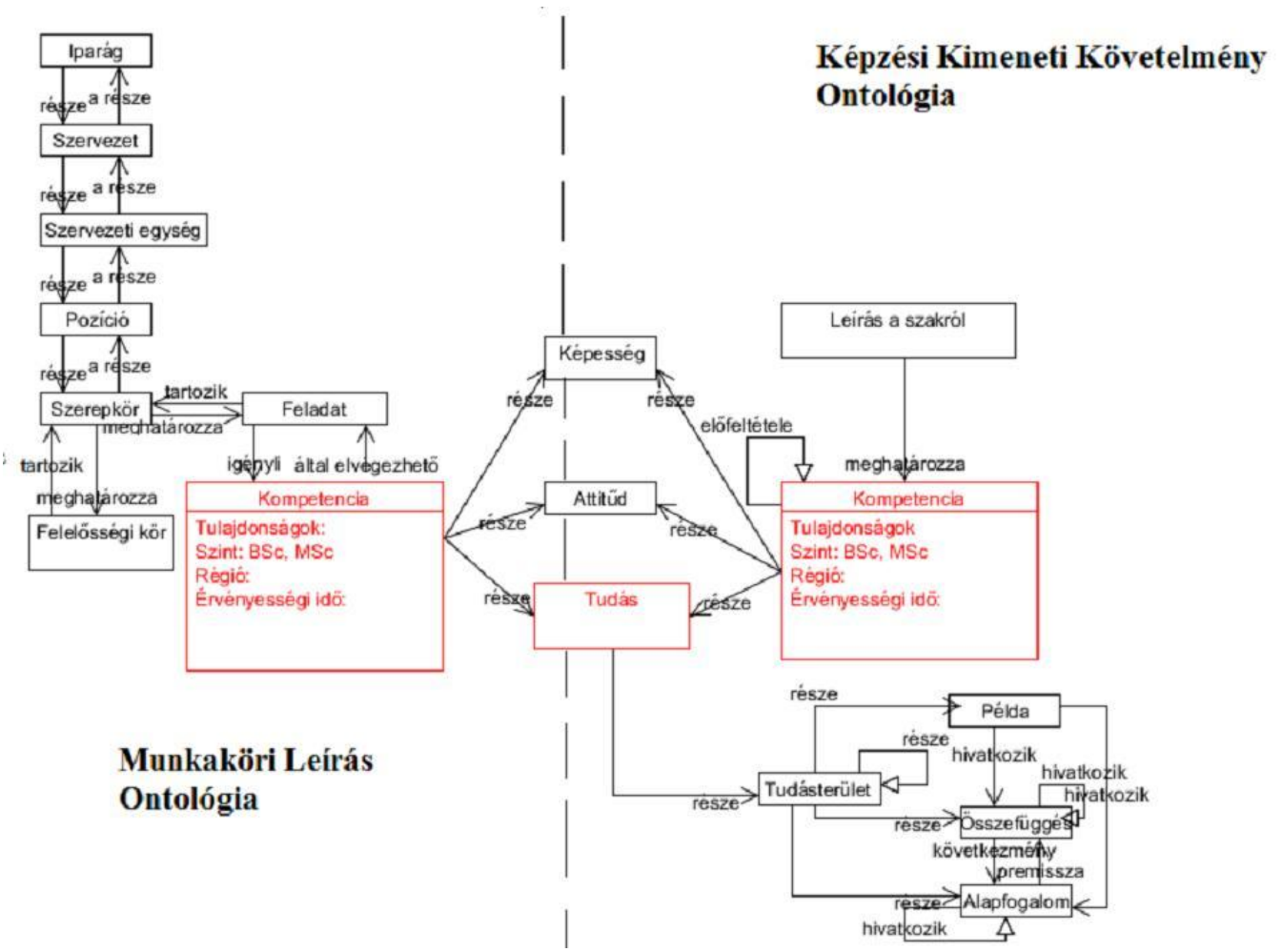

10. ábra Munkaköri Leírás Ontológia és a Képzési Kimeneti Követelmény Ontológia

Egy Iparág bizonyos Szervezetén belül a Szervezeti egység Pozícióinak hatáskörébe tartozik az egyes Feladatok elvégzése, amelyek viszont a Pozíció Szerepköreihez kapcsolódnak. A döntéseket igénylő Szerepkörhöz Felelősségi kör is tartozik. A munkavállalónak a Feladat elvégzéséhez alkalmaznia kell tudnia a Feladat által igényelt Kompetenciát. A kompetenciák időbeli és térbeli strukturáltságát biztosítja a tulajdonságokként megjelenő régió, valamint érvényességi idő attribútum. Az igényelt kompetencia szintjét a szint attribútum adja meg. Ahogy a II.3 fejezetben láttuk a kompetencia tartalmilag a Képesség, Tudás, valamint az Attitüdök területekre építkezik.

Az Iparág, Szervezet, Szervezeti egység, valamint a Pozíció írják le a kompetenciák szervezeti hátterét. Ahogy a II.2 fejezetben is láttuk a kompetencia szorosan kapcsolódik egy feladathoz, vagy szerepkörhöz, illetve dinamikusan kerül felhasználásra. Ezért a meta-modell központi elemét a Pozíció, Szerepkör, Feladat, valamint a Kompetencia osztály képezi, amelyek példányai az aktuális állásajánlatok alapján történő frissítés során nyert tér-, és időbélyeg által hordozzák magukban a változásokat. Az egyes osztályok definícióját a következőképpen határoztuk meg: 
Pozíció: „a szervezetben különféle szerepkörökhöz tartozó munkafeladatok és felelősségek együttese, melyeket egyének látnak el (töltenek be). Egy szervezetben annyi pozíció van, ahány munkavállaló." (Bakacsi, 2005 pp.102).

Feladat: tevékenységek azon részhalmaza, amely valamilyen döntési szituációhoz kapcsolódik. Ezáltal azok a rutin tevékenységek (pl. változó definiálása a programban), amelyek a kompetenciák készségből való alkalmazását igénylik, nem kerülnek felvételre. Itt jegyezném még, hogy eltérő szerepköröknél ugyanaz a tevékenység nem feltétlenül rutin tevékenységként jelenik meg.

Szerepkör: szerepkörök által definiált feladatok elvégzéséhez kapcsolódó elszámoltathatóság, legtöbbször döntési helyzethez kapcsolódik.

Felelősségi kör: a szerepkörök által definiált folyamatok elvégzésének a felelössége.

A kapcsolatok kardinalitását a 2. melléklet tartalmazza.

A munkaerőpiac kínálati oldalán a kompetenciák a szakot meghatározó forrásokból azaz az oktatók véleményéből lettek - kinyerve, így biztosítva a kontextusba helyezést. Az OntoHR projekt alapjául szolgáló ontológia annyiban változott meg, hogy az elsősorban intelligencia elemekre fókuszáló Mental Ability osztály helyett az általánosabb Képesség (Skill) osztály, valamint az Attitüd osztályok lettek felvéve. Illetve a Kompetencia osztály gazdagabb lett egy a kompetencia szintet mutató, a képzés helyét, valamint a kompetencia érvényességi idejét reprezentáló attribútummal.

(A továbbiakban az Attitüdök osztállyal nem foglalkoztam, ugyanis az adott képzés során célzottan nem fejlesztünk attitüdöket.)

\section{IV.1.3. Ontológia formalizálását elősegítő eszközök}

Az implementálás megkezdése előtt figyelembe kellett vennem, hogy melyek azok az ontológia-leíró nyelvek, ontológiafejlesztő eszközök, illetve módszertanok, amelyek magukban hordozzák az egymáshoz illesztés lehetőségét. Ahogy Noy (2004) rámutatott a következtetés az ontológia-integrációs megközelítések középpontjában áll, ezért azok az ontológia-leíró, illetve fejlesztő eszközök kerülnek most bemutatásra, amelyek a következtetési mechanizmusok kialakítását is támogatják. Az ontológiafejlesztő módszertanok ismertetésére azért nem helyezek hangsúlyt, mert az implementálni kívánt meta-modellek már meglévő ontológiákból építkeztek. 


\section{IV.1.3.1. A specifikációt elösegítő tudásábrázolási módok és nyelvek}

A számítógépes értelmezéshez igényelt specifikáció kidolgozásához szükség van a korábban felvázolt fogalomalkotási folyamatot leképező ismeretreprezentációs ábrázolási módra, illetve egy olyan nyelvre, amely elősegíti az ismeretek formalizálását, azaz a folyamat elemeire (osztályokra, tulajdonságokra, kapcsolatokra) történő hivatkozást.

\section{Ismeretreprezentáció}

Mesterséges intelligencián belüli önálló tudományterület, amely Futó (1999 pp. 974) megfogalmazásában az ,adott tárgykörről szerzett ismeretek ábrázolása olyan szerkezetben, amely megkönnyíti a tárgykörben felmerülő problémák megoldását.” Az ábrázolás alapját képezik a tudásreprezentációs formalizmusok és az ezen végrehajtott következtetések. Sowa (2000), aki a formalizálásra nagyobb hangsúlyt fektetett, ki is egészíti a mesterséges intelligencia kutatásokban használt tudásreprezentációs technikákat az adatbáziskezelés és az objektumorientált rendszereknél használtakkal. Ezért ő úgy tekint erre a tudományterületre, amely a tárgyterület számítógépes modelljének megkonstruálását teszi lehetővé a logika és az ontológia együttes alkalmazásával (Shapiro, 2001). A következő részben bemutatom, hogy a legfontosabb ábrázolási módok és a hozzájuk kapcsolódó ontológia-leíró nyelvek hogyan járulnak hozzá az illeszkedési vizsgálatot lehetővé tevő modellek implementációjához.

\section{Logikaalapú reprezentáció}

A mesterséges intelligenciában a logika nyelve, a predikátumkalkulus alkalmas gyakorlatból vett problémák formalizálására. Azzal, hogy kellően rugalmas a bonyolult állítások leírására, pontos szintaxissal rendelkezik, illetve az általa használt bizonyító eljárás pedig helyes és teljes (azaz megoldható vele - amennyiben a feladat is az minden formalizálható feladat). Mindez hozzájárul ahhoz, hogy a logika elsődleges deklaratív ismeretábrázolási módja legyen. Ezt az ismeretreprezentációs technikát már ebben a formában gyakorlatilag nem használják, de a logikának fontos szerepe van a szabályalapú következtetés, vagy a szemantikus háló kifejezőerejének vizsgálatakor.

A nulladrendü- (itéletkalkulus), az elsőrendü-, illetve másodrendủ predikátumkalkulus egymásra épülve, egymást kiegészítve kívánja a tudást reprezentálni. Amíg az 
itéletkalkulus köznapi értelemben igaz, vagy hamis, kötőszavakkal összekapcsolt egyszerủ részmondatokból álló kijelentő mondatok absztrakt formalizálásra alkalmas, addig az elsőrendủ predikátumkalkulusban ezt kiegészítve már egy alaphalmaz elemeire vonatkozva, függvények, predikátumok, konstansok, változók felhasználásával fogalmazhatók meg az igaz, vagy hamis kijelentéseink, illetve bevezetődnek az univerzális (minden) és az egzisztenciális (létezik) kvantorok is. Azonban amíg itt a változók csak objektumokat helyettesíthetnek, addig a másodrendü logikában már reláció-, vagy függvényértékủ változóink is lehetnek. A formulák egyik esetben sem tükrözik az eredeti állítások tartalmát, csak azok szerkezetét. Így azzal nyernek szemantikai tartalmat, hogy az ítéletváltozókat logikai igaz, vagy logikai hamis értékek hozzárendelésével interpretáljuk, valamint ezen interpretáció alapján logikai műveletek segítségével a mondatok igazságértéke kiértékelésre kerül. Az összes lehetséges interpretáció elvégzése után kapunk egy teljes képet a formula jelentéséről.

A rezolúció egy olyan tételbizonyító eljárás, amely alkalmas a formula érvényességének (minden interpretációban igaz), illetve kielégíthetetlenségének (minden interpretációban hamis) vizsgálatára, amennyiben a megfelelő reprezentációval elkerüljük azt, hogy végtelen ciklusba kerüljön az eljárásunk. Mindemellett kérdés-felelet problémák megoldására is alkalmas (Fekete, 1999).

A leíró logika az elsőrendű logikához képest nagyobb kifejező erővel rendelkezik, valamint eldönthető és hatékonyabb következtetési eljárás adható hozzá. Fogalmak (egyedek valamely összességének közös sajátosságait leíró fogalmak), szerepek (egyedek közötti bináris relációk, azaz olyan függvények ${ }^{13}$, amelyek a fogalomhoz rendelik hozzá a tulajdonságot), valamint egyedek képezik a nyelv alapvető elemeit. A nyelvi szerkezet lehetővé teszik új fogalmak, szerepek képzését (Sántáné-Tóth, 2006 pp.12).

Az elsőrendű logikára épülő ontológiai nyelvek a Cycl és a KIF. A Cyclet a Cyc projekt keretében fejlesztették ki a közös értelmü tudás általános ontológia formában történő megfogalmazása miatt. A valóságbeli fogalmak kifejezésére szolgál a kb. 160 termből álló szójegyzék, amelyek összekombinálásából keletkeznek az értelmes Cycl kifejezések. A Cycl fö fogalmai közé tartoznak a konstansok (pl. dolog, fogalom stb.), változók, formulák (termekbe, kifejezésekbe történő kombinálása), predikátu-

\footnotetext{
${ }^{13}$ Olyan leíró logikában alkalmazható, ahol a szerepek aritása kettőre van korlátozva (Sántáné-Tóth, 2006).
} 
mok (termek közötti kapcsolatok kifejezésére), illetve mikroteóriák. Ez utóbbi a formulák egy olyan halmaza, amely a formula igazságának kontextusát biztosítja ( $\mathrm{Su}$ Ilebrekke, 2006). A Cyc következtetési motor általános logikai dedukciót (pl. modus ponens) hajt végre MI-beli következtetési mechanizmusokkal (öröklődés, automatikus osztályozás stb.) együtt. Heurisztikákat használ, és a mikroteóriák segítségével korlátozott keresési tartományra építve optimalizálja az eredményt (Cycorp, 2011).

A KIF (Knowledge Interchange Format) egy olyan formális nyelv, amely a különböző számítógépes programok tudáscseréjére szolgál. Azonban nem célja sem a felhasználók közötti interakció elsődleges nyelvévé válni - bizonyos esetekben kivételt tesznek pl. tudásbázis fordítási problémák interpretálása során -, sem a programokon belüli tudásábrázolás eszközévé válni (bár lehetővé teszi annak a használatát). Ezért a programok kommunikációja alatt az adatok oda-vissza átkonvertálódnak a KIF és a külső program adatstruktúrája között. A nyelv a következő lényeges tulajdonságokkal rendelkezik

- deklaratív szemantikája van, azaz külső interpreter használata nélkül lehetővé teszi a kifejezések jelentésének az értelmezésért.

- a predikátum kalkulusban történő ábrázolásnak köszönhetően logikailag teljes nyelv.

- expliciten meghozhatók tudásábrázolási döntések, a nyelv megváltoztatása nélkül készíthetőek új tudásábrázolási konstruktorok (Genesereth et al., 1992). Ráépül a keretalapú Ontolingua szintaktikája és szemantikája.

Az egyes illeszkedést vizsgáló módszerek közül az ontológiai morfizmust keresők (pl. LOM, IF-MAP) logikai elméletekre épülnek.

\section{Szabályalapú ismeretreprezentáció}

Az ismeretek szabályalapú ábrázolása alkalmas a köznapi gondolkodás modellezésére, ezért napjainkban is nagy gyakorlati jelentőséggel bír az MI alkalmazások területén. A szabályok alkalmazásával fogalmazhatjuk meg egy tárgyterület tényeit, azok relációit, a meglévőekből új tényeket előállító következtetési ismereteket, valamint ezen folyamat vezérlését befolyásoló metaismereteket. A szabályok formailag $h a A$, akkor $B$ szerkezetüek, ahol A képviseli a feltételrészt tényállítások, illetve ezekből és/vagy kötőszóval kombinált állítások formájában, míg B adja a következményrészt, 
azaz megadja, hogy az A feltétel teljesülése esetén milyen akciónak, tevékenységnek, érvényes állításnak, vagy müveletnek kell bekövetkeznie. A következtetési stratégia kiindulhat egy kezdőállapotból, vagy egy célállapotból is. Az előbbi esetén, az adatvezérelt következtetés keres valamilyen megoldást jelentő célállapotot, míg az utóbbi esetében a célvezérelt következtetés a kiindulás célállapot a rendszer által ismert tényekből, vagy már korábban igazolt állításokból való elérhetőségét kívánja bizonyítani. Mindkét stratégia esetében a rendszer előállítja a kezdőállapotból a célállapotba vezető utat (Bognár, 2010).

A két ontológia felépítése, összehasonlítása szabályok alkalmazását igényli, ezért a szabályalapú programozási nyelvek közül a továbbiakban a logikai programozás irányzatának fö képviselőjét a Prologot, a szövegfeldolgozást egyszerüvé tevő Awkot, valamint az ontológiaszerkesztő környezeteknél elterjedt Jess, SWRL és FaCT nyelvet mutatom be.

A Prolog programokban állításokat fogalmazunk meg a logika nyelvén a predikátum fogalomra építve, majd tételbizonyító eljárással hajtjuk azokat végre. Az állítások lehetnek tényállítások, vagy szabályok. A tényállítások esetében a predikátum nevét követik, a predikátum argumentumai, amik lehetnek szám-, vagy névkonstansok. Kérdéseket tehetünk fel, amelyben vagy egy konkrét állítás fennállására kérdezünk rá, vagy egy nyitott kérdést teszünk fel oly módon, hogy a predikátum egyes argumentumait változókra cseréljük. A szabályokat olyan Ha A, akkor B típusú logikai állításokként is lehet értelmezni, amelynek a fej részében szerepel a következmény, míg az ettől :- jellel elválasztott törzs részében szerepel a feltétel, amelyben szereplő változók univerzális kvantorokkal együtt értelmezhetök. A program deklaratívan történő értelmezése során logikai formulaként értelmezzük az állításokat, így a kérdésre adott válasz egy olyan a változókba történő behelyettesítés-rendszer, amellyel a programból, mint logikai formulák halmazából levezethetővé válik a kérdés. A procedurális értelmezés viszont azt az algoritmust írja le, amivel végrehajtódik a program ez lehet pl. egy célvezérelt keresés is (Szeredi, 1999).

Awk általános célú programozási nyelv és szkriptelő környezet, amely többek között szöveges állományok feldolgozását, kisebb, személyes adatbázisok kezelését, indexelést, vagy más dokumentum előkészítési feladatokat tesz lehetővé. A GNU projekt keretében implementált Awk, a Gawk adatdarabok, bitek feldolgozásra előkészítését, adatok rendezését, valamint egyszerü hálózati kommunikációt tesz lehetővé. Szintak- 
tikailag a szabályok /mintázat/\{parancsok\} formájában épülnek fel. Azaz a szöveg, adatbázis mintaillesztéssel történő feldolgozása során a feltételként megadott megfelelő mintázat megtalálása a parancsok végrehajtását indukálja. Mindemellett függvények, elágazások, más algoritmikus elemek is használhatók. (Gawk, 2010)

A Jess Java nyelven íródott szabály alapú következtető motor. A deklaratív szabályok formájában megadott tudáson való célvezérelt következtetést, lekérdezéseket tesz lehetővé. A szkriptelö környezetnek köszönhetően Java objektumokat lehet létrehozni, Java metódusokat lehet hívni, illetve Java interfészeket lehet implementálni vele a Java kód fordítása nélkül. Tényeket, és szabályokat lehet definiálni, de lehetőség van függvények hívására is. A szabályok két formátumban a Jess nyelven, vagy XML formátumban adhatók meg, amelyek a következtető motor futtatásával értékelődnek ki, ezáltal új adatokat tudnak létrehozni, vagy bármi olyat végre tudnak hajtani, amire egy Java program képes. LISP-hez hasonló szintaxtisa van (Friedman-Hill, 2008).

FaCT (Fast Classification of Terminologies) egy leíró logikai osztályozó, amely ontológiák konzisztenciájának ellenőrzésére, valamint automatikus osztályozásra szolgál. Axiómákat tartalmazó általános fogalmi leírásokkal rendelkező ontológiákon való következtetést tesz lehetővé. Nyílt forráskódú, Lisp-alapú rendszer. Nagy gyakorlati jelentősége ontológiafejlesztő környezetbe (Protégébe) történő integrációja (Horrocks, 2003).

SWRL (Semantic Web Rule Language) az OWL DL és OWL Lite RuleML-lel való összekombinálásból született azzal a céllal, hogy különböző relációk egymással való kapcsolatát lehessen vele modellezni, ezáltal javítva az OWL kifejezőerejét. Az OWL axiómákat Horn-típusú szabályokkal egészíti ki. A szabályok az előzmény és a következmény közötti implikációk formájában vannak megadva. Azaz ha a feltételek az előzményben teljesülnek, akkor a következményben megadott feltételeknek is teljesülniük kell (Horrocks et al., 2004)

A logikai programozási nyelvek közül a FaCT, SWRL, illetve Jess bővíti az egyes ontológiafejlesztő környezet pl. Protégé funkcionalitását, azaz segítségül hívhatók ontológia konzisztenciájának vizsgálatára, vagy a fejlesztő környezeten belüli illeszkedésvizsgálatot célzó szabályok megvalósítására. Az AWK lehetőséget biztosít szö- 
veges állományok átalakítására, ami az ontológiába történő adatimportálást segítheti elő.

\section{Szemantikus hálózatok}

A kognitív pszichológia területén végzett kísérletek alapján a kutatók feltételezték, hogy az emberek a tárgyköri ismereteiket háló formájában tárolják el, mégpedig oly módon, hogy a világ objektumait hierarchikus felépítésbe rendszerezik, a tulajdonságokat pedig nem az egyes egyedekhez, hanem az osztályukhoz kapcsolják.

„A szemantikus háló egy irányított, címkékkel ellátott gráf, ahol a csúcsok az objektumokat, tulajdonságaikat, a tulajdonságok értékeit tartalmazzák, az összekötő élek pedig a csúcsok közti relációkat fejezik ki” (Bognár, 2010). Az osztályokat halmazoknak tekintjük, a relációk kifejezhetnek részhalmaz relációkat, objektum osztályhoz tartozását, valamint tulajdonságokat is leírhatnak. A szemantikus háló jellemző tulajdonsága az öröklődés, azaz egy objektum, vagy osztály automatikusan örökli a befoglaló, illetve tartalmazó osztályok összes tulajdonságát.

Ez a grafikus hierarchikus ismetreprezentálási mód, támogatja az automatikus következtetéseket is oly módon, hogy a tárgyterület ismereteiből felépített hálóra (tényhálóra) ráilleszti a megválaszolni kívánt célállítást, vagy kérdést reprezentáló célhálót. Az illesztés során vagy talál egy részgráfot, amelyben a csomópontok és az élek is hasonló nevüek, vagy ha a tulajdonság nem szerepel az objektum alatt közvetlenül, akkor a hierarchiában felfelé haladva ez eleme, részhalmaza,... stb. éleken haladva keres tovább. Mivel az általánosan érvényes tulajdonságokat az osztály szintjén, a kivételeket az objektum szintjén tárolja, és az illesztési mechanizmus ez utóbbinál megáll, hogyha megtalálta az adott tulajdonságot, ezért ily módon a szemantikus háló alkalmas kivételek eltárolására és kezelésére is. Mindemellett az ellentmondások feloldása is megoldható, ha az él előfordulásokhoz prioritásokat rendelünk, vagy megadjuk, hogy melyik él legyen az alapértelmezett. Ezáltal ugyanis, hogyha egy objektum, vagy osztály két, vagy több osztálytól egymást kizáró tulajdonságot örököl, ki lehet választani, hogy ezen élek közül melyiket tekintjük érvényesnek (Fekete, 1999).

A szemantikus hálózatok közül vannak olyanok, amik az emberi kognitív mechanizmusokra vonatkozó hipotéziseket implementálnak, míg mások elsősorban a számítógépek hatékonyságát kívánják megnövelni (Sowa, 1992). 


\section{Keretalapú ismeretábrázolás}

A keretalapú ismeretábrázolás a szemantikus hálók továbbfejlesztése oly módon, hogy a grafikusan megjelenített hálót sajátos nyelven írjuk le, ami lehet egy absztrakt nyelv, vagy konkrét implementált nyelv. A keret vagy frame, a tanulmányozott világ egy fizikai vagy fogalmi entitásának strukturált szimbolikus modelljeként történő leírása. Itt az osztályokra már nem halmazokként, hanem a :Class metaosztály prototípusegyedeként tekintünk. Ebben az esetben az osztályhoz való tartozás nem mást jelent, mint a prototípus konkrét értékekkel történő ellátását, vagyis példányok képzését. A korábban részhalmaz osztályhoz most úgy jutunk el, hogy az őt tartalmazó osztálynak megfelelő prototípust specializáljuk.

Az attribútumok reprezentálják az élcímkéket, ami a nyelvi leírásnak köszönhetően precízebben megfogalmazhatóvá, értelmezhetővé válik. Az attribútum nem lesz más, mint egy reláció, amelynek az értelmezési tartománya azok a keretek, amelyben szerepel, értékkészlete, pedig azok az értékek (osztályok, vagy egyszerü típusok), amiket felvesz. Keret formájában is leírhatjuk, ebben az esetben a :Slot metaosztály prototípusegyedei lesznek az attribútumok, amelyek többek között rendelkeznek a domain (értelmezési tartomány), range (értékkészlet), constraint (értékkészletre vonatkozó korlátozás), default (alapértelmezett érték), inverse (inverz reláció), és az inheritance (öröklődés) bejegyzésekkel. Az osztályok, vagy egyedek attribútumaihoz eljárásokat is rendelhetünk.

A sajátos nyelvre történő megfogalmazás során megengedjük, hogy egy osztály több osztálynak is részhalmaza legyen (többszörös osztály fogalom), egy példány több osztály példánya legyen (többszörös példány fogalom). A leírás továbbra is a szemantikus hálónál látható hierarchiát tükrözi oly módon, hogy az „alján” találhatóak a példányok, mivel ezeket már nem tudjuk tovább példányosítani. A kereteknél az öröklödésnek ugyanaz a mechanizmusa érvényesül, mint a szemantikus hálóknál (Fekete, 1999).. 


\section{Keretalapú ismeretábrázolást támogató ontológia-leíró nyelvek}

Az Ontolingua olyan keret-alapú nyelv, amelynek KIF-et kiterjesztő szintaktikája és szemantikája van. Osztályok, relációk, függvények, objektumok, valamint teóriák (definíciók nevesített halmazának) meghatározását, valamint ezekre vonatkozó kijelentések megadását teszi lehetővé. A tudást olyan objektum központú hierarchiába szervezi, ahol az öröklődés is engedélyezett. Célja egy olyan ontológia készítő mechanizmus biztosítása, amely segítségével az ontológiák átfordíthatóak, s ezzel különböző reprezentációs és következtető rendszerek által értelmezhetővé válnak (Gruber, 1992). Nagy kifejezőerővel bír, azonban nincs hozzá következtető rendszer (Vas, 2007).

RDF egy olyan W3C szabvány, amely a dokumentumok transzformálására és lekérdezésére szolgál oly módon, hogy a dokumentumokhoz szemantikát lehet rendelni. Mindezt úgy éri el, hogy standardizálja a web-alapú források meta-adat leírásainak használatát és definícióját, ezáltal biztosítva a fent említett kötöttséget. Az alap építőeleme az objektum-attribútum-adat hármas, ahol az objektum betöltheti az érték szerepét is. Így felépíthetővé válik egyfajta struktúra a fogalomosztályok között pl. a kórokozók osztályát alkotják a vírusok és a baktériumok osztályai. A nyelv egy továbbfejlesztése az RDF Schema, amely úgy tartja meg az RDF szintaktikáját, hogy nem korlátozza a tagek kombinációjának sorrendjét, információt biztosít az RDF adatmodellben adott kifejezések interpretációjáról és modellező primitíveket tartalmaz (osztályok, alosztályok, tulajdonságok, altulajdonságok). Lehetővé teszi a fejlesztő számára, hogy egyedi szókészletet definiáljon az RDF adat számára és meghatározza azoknak az objektumoknak a fajtáját, amelyekre ezek a tulajdonságok érvényesek. Az RDF objektumok egyedként is szolgálhatnak. A tulajdonságokat meghatározhatják értelmezési tartomány, vagy értékkészlet megadásával és így létrejöhet ezeknek egyfajta hierarchikus struktúrája. Mindezen előnyök mellett a következő hátrányokkal rendelkezik: pl. egy osztálynak nem lehet egyszerre egymást kizáró két tulajdonsága (egy könyv nem jelenhet meg keménykötésben, illetve nem keménykötésben), vagy a tulajdonságok nem rendelkezhetnek más-más adattípussal (egy könyv címe nem lehet szöveg, úgy, hogy az ára szám típusú) stb. Mindebből az következik, hogy gazdagabb nyelvre van szükség.

Ilyen például az OIL (Ontology Inference Layer) és az erre épülö DAML (DARPAgent Markup Language)+OIL. Az OIL formális szemantikát és hatékony 
következtetést biztosít, gazdag modellező primitívekkel rendelkezik, és képes szabványos javaslatot adni szintaktikus információ-csere jelölésére. Azaz egyesíti magában a leíró logikák, a keretalapú rendszerek és az XML, illetve RDF elönyeit. A DAML+OIL elsősorban az RDFS-re építkezik. (Fensel et al., 2002).

Az OWL Web Ontológia Nyelvet az információ tartalmának gépi feldolgozására fejlesztették ki. A DAML+OIL továbbfejlesztett változata, amely gazdagabb szókészletet nyújt a tulajdonságok és osztályok leírásához. Lehetővé teszi osztályok közötti viszonyok leírását (pl. különálló halmazokhoz tartozás), kardinalitás (pl. "kizárólag egy"), egyenlőség, a tulajdonságok gazdagabb tipizálását, tulajdonságok jellemzőinek beállítását (pl. szimmetria) stb. Három, rendre növekvő kifejező erejü alnyelve van:

- Osztályozási hierarchiákat és egyszerü korlátozásokat használni kívánó fejlesztői csoportok munkáját támogatja az OWL Lite.

- Az OWL DL azon felhasználók munkáját segíti, akik a teljes számíthatóság és az eldönthetőség megtartásával igénylik a maximális kifejezőképességet mégpedig úgy, hogy minden konklúzió garantáltan kiszámítható, és minden számítás véges időn belül be is fejeződik.

- Az OWL Full alnyelv azon fejlesztői közössége számára készült, akiknek maximális kifejező erőre és az RDF szintaktikai szabadságára van szükségük, de ennek fejében lemondanak a kiszámíthatósági garanciákról.

Az OWL 2 (OWL Working Group, 2009) az OWL-DL felhasználók által igényelt továbbfejlesztése. Többek között olyan új jellemzőkkel rendelkezik, mint két új konstruktor hozzáadása (DisjointUnion, valamint NegativeObjectPropertyAssertion és NegativeDataPropertyAssertion) a közös kifejezések egyszerübb megfogalmazásáért; további tulajdonság és minőségi kardinalitási korlátozások; felhasználók által definiált adattípusok támogatása; asszimetrikus, reflexív és diszjunkt tulajdonságok megadása, javított annotációs képességek stb érdekében.

A web alapú nyelvek szemantikai jelentést kívánnak adni a dokumentumoknak, azaz a meta-modell szakmai, illetve foglalkozási specializációjának kialakításában van szerepük. (OWL Working Group, 2009)

A szakterületi ontológiák formalizálásához attól függően választhatunk ismeretreprezentációs technikát, illetve ontológia-leíró nyelvet, hogy milyen módon - elsősorban 
deklaratív (logika), vagy azt procedurális hozzárendeléssel kiegészített módszerrel (keret-alapú) - kívánjuk a III.1 fejezetben bemutatott propozícionális gondolkodás folyamatát leképezni. Az egyes fejlesztési fázis esetlegesen különböző - pl. az ontológiaépítés során keret-alapú, míg az illeszkedés vizsgálatakor logika alapú - nyelvekkel való támogatása esetében figyelembe kell venni azok egymásba való konvertálhatóságának a meglétét. A megfelelő leíró nyelv kiválasztását mindemellett az is befolyásolja, hogy milyen ontológiaszerkesztő eszköz alkalmas leginkább arra, hogy a különböző dokumentumokból a szakmai, illetve foglalkozási oldalon olyan ontológiák készüljenek, amelyek előrevetítik azok egymáshoz illesztésének a lehetőségét.

\section{IV.1.3.2. Ontológiaszerkesztö eszközök}

Számos tanulmány foglalkozik a különböző ontológiaszerkesztő eszközök bemutatásával. Ezek közül én Vas (2007) munkájára támaszkodva azon eszközöket vizsgáltam meg a kutatásban való alkalmazhatóság szempontjából, amelyek következtető rendszerrel rendelkeznek. A fejlesztésnek ebben a fázisában olyan eszközre volt szükség, amely automatikus adatimportálást tett lehetővé, valamint szabályok, esetlegesen algoritmusok megadásával megalapozta az ontológiák illeszkedésvizsgálatát. A tanulmány által vizsgált kilenc eszköz közül a beépített, valamint hozzáilleszthető következtető géppel rendelkező Ontosaurust ${ }^{14}$ tartalmazó PowerLOOM $^{15}$, az utoljára 2006-ban javított WebOde helyett a szemantikus integrációra képes OntoStudio $^{16}$-t, a Protégé környezet legújabb verzióit a Protégé 3.x, illetve Protégé 4.x ${ }^{17}$ fejlesztő eszközöket, valamint a SAKE projektben használt implementálási környezetet a KAON $\mathbf{2}^{\mathbf{1 8}}$-t elemeztem az alábbi szempontok szerint:

A program általános jellemzői (3. táblázat) közé tartozik a fejlesztő neve, a szoftver verziószáma, az eszköz létrehozásának a célja (milyen fejlesztési munkálatokat támogat), valamint az, hogy milyen nyelveken való formalizálást tesz lehetővé.

\footnotetext{
${ }^{14} \mathrm{http}: / /$ www.isi.edu/isd/ontosaurus.html

$15 \mathrm{http}: / /$ www.isi.edu/isd/LOOM/PowerLoom/

${ }^{16} \mathrm{http}: / /$ www.softpedia.com/get/Science-CAD/OntoStudio.shtml

${ }^{17} \mathrm{http}: / /$ protege.stanford.edu

${ }^{18} \mathrm{http}: / /$ kaon2. semanticweb.org/
} 


\begin{tabular}{|c|c|c|c|c|}
\hline & Fejlesztő neve & Verziószám & Célja & Nyelv \\
\hline PowerLOOM & $\begin{array}{c}\text { ISI, University of } \\
\text { Southern California }\end{array}$ & $\begin{array}{c}\text { PowerLoom } \\
4.0 \text { beta } \\
(2012)\end{array}$ & $\begin{array}{l}\text { Intelligens és tudásala- } \\
\text { pú alkalmazások szá- } \\
\text { mára kifejező, logikai } \\
\text { reprezentációs nyelv, } \\
\text { valamint fejlesztő kör- } \\
\text { nyezet biztosítása }\end{array}$ & $\begin{array}{l}\text { KIF-alapú } \\
\text { nyelvek }\end{array}$ \\
\hline OntoStudio & Ontoprise $\mathrm{GmBH}$ & $3.2(2012)$ & $\begin{array}{l}\text { Ontológia készítése és } \\
\text { karbantartása grafikus } \\
\text { szabályszerkesztő és } \\
\text { automatikus adatimpor- } \\
\text { tálási, leképezési esz- } \\
\text { köz támogatásával }\end{array}$ & $\begin{array}{l}\text { ObjectLogic, } \\
\text { OWL, RDF }\end{array}$ \\
\hline \multirow[t]{2}{*}{ Protégé } & \multirow[t]{2}{*}{$\begin{array}{c}\text { SMI, Stanford Uni- } \\
\text { versity }\end{array}$} & $\begin{array}{c}\text { Protégé 3.4.6 } \\
\text { (2011. ápri- } \\
\text { lis) }\end{array}$ & \multirow{2}{*}{$\begin{array}{l}\text { Növekvő számú fel- } \\
\text { használói közösség } \\
\text { számára kíván ontoló- } \\
\text { gia alapú rendszerek } \\
\text { fejlesztéséhez, vala- } \\
\text { mint modellezéshez } \\
\text { eszközöket nyújtani. }\end{array}$} & $\begin{array}{c}\text { Keret-alapú } \\
\text { ontológiákat } \\
\text { megalapozó } \\
\text { nyelvek: } \\
\text { OWL } 3 \\
\text { alnyelve, } \\
\text { RDF(S), XML }\end{array}$ \\
\hline & & $\begin{array}{l}\text { Protégé 4.1, } \\
4.2 \text { (2011. } \\
\text { május, ill. } \\
\text { 2012. július) }\end{array}$ & & $\begin{array}{l}\text { OWL } 2.0 \\
\text { RDF }\end{array}$ \\
\hline Kaon2 & $\begin{array}{l}\text { FZI Research Center } \\
\& \text { AIFB Institute, } \\
\text { University of Karls- } \\
\text { ruhe IPE Information } \\
\text { Process Engineering }\end{array}$ & $\begin{array}{l}29.06 .2008 \\
(2008 . \text { júni- } \\
\text { us) }\end{array}$ & $\begin{array}{l}\text { Üzleti alkalmazások } \\
\text { számára ontológiame- } \\
\text { nedzsment infrastruktú- } \\
\text { ra } \\
\text { Kaon utódja }\end{array}$ & $\begin{array}{l}\text { OWL-DL, } \\
\text { SWRL, F- } \\
\text { logic }\end{array}$ \\
\hline
\end{tabular}

3. táblázat Általános jellemzők

Az automatikus adatimportálást (4. táblázat) a következő jellemzők támogatják:

- letölthető nyílt forráskód: a program hosszú távú karbantarthatóságát biztosítja licenszszerződéstől való függőség nélkül. 
- szoftver dokumentálása: a továbbfejlesztésének, alkalmazhatóságának előfeltétele, hogy a szoftver olyan dokumentációval rendelkezzen, amelyből kiindulva a fejlesztés megvalósulhat.

- dokumentumtípusok importálási lehetősége: a dokumentumokat valamilyen előzetes szövegfeldolgozó eszközzel (pl. awk) olyan formára hozhatjuk, amelyet a szerkesztő eszköz már kezelni tud. Ilyen formátumok lehetnek pl. szövegformátumok, illetve az XML. Ezért érdemes megnézni, hogy az eszköz képes-e ezen formátumok alapján ontológia készítésére.

\begin{tabular}{|c|c|c|c|}
\hline & $\begin{array}{l}\text { Letölthető nyílt } \\
\text { forráskód }\end{array}$ & Dokumentáció & Dokumentum importálása \\
\hline PowerLOOM & igen & $\begin{array}{c}\text { Felhasználói } \\
\text { könyv, tutorial, } \\
\text { Javadoc }\end{array}$ & Flat file adatbázisok \\
\hline OntoStudio & $\begin{array}{l}\text { nyílt forráskód } \\
\text { helyett három } \\
\text { hónapos próba- } \\
\text { verzió }\end{array}$ & $\begin{array}{l}\text { videóbemutató, } \\
\text { online help }\end{array}$ & $\begin{array}{c}\text { UML 2.0 } \\
\text { Adatbázis sémák (Oracle, } \\
\text { MS-SQL, DB2, MySQL) } \\
\text { Excel táblázatok } \\
\text { Outlook levelek } \\
\text { könyvtárstruktúrák }\end{array}$ \\
\hline Protégé 3.x & igen & $\begin{array}{l}\text { Felhasználói } \\
\text { könyv, tutorial, } \\
\text { Javadoc }\end{array}$ & $\begin{array}{c}\text { XML, RDF(S), XML Shema, } \\
\text { DataMaster pluginnal: } \\
\text { JDBC/ODBC adatbázis } \\
\text { EXCEL táblázat }\end{array}$ \\
\hline Protégé 4.x & igen & $\begin{array}{c}\text { Felhasználói } \\
\text { könyv, tutorial, } \\
\text { Javadoc }\end{array}$ & nincs, de plugin írható hozzá \\
\hline Kaon2 & $\begin{array}{l}\text { igen, egyetemek } \\
\text { számára kutatási } \\
\text { célra }\end{array}$ & Javadoc, példák & $\begin{array}{c}\text { OWL XML Presentation Syntax, } \\
\text { OWL RDF Syntax }\end{array}$ \\
\hline
\end{tabular}

4. táblázat Automatikus adatimportálás

Az illeszkedésvizsgálatot (5. táblázat) az alábbi jellemzők alapozzák meg: 
- összeépíthetőség, bővíthetőség: mivel a következő fázisban egy illeszkedésvizsgálatot végző eszköz, vagy algoritmus kiválasztására, kifejlesztésére került sor, ezért kérdéses molt, hogy az itt kiválasztott eszközt össze lehet-e kapcsolni valamilyen külső programmal, vagy ki lehet-e bővíteni saját algoritmussal. Ez utóbbit vizsgálja a következő kritérium.

- következtető gép jellemzői: a rendszer beépített, vagy illesztett következtető gépe milyen módon alkalmas új algoritmus végrehajtására.

- beépített illeszkedésvizsgálat: van-e olyan funkciója, amely az ontológiák egymáshoz illesztését vizsgálja.

\begin{tabular}{|c|c|c|c|}
\hline & $\begin{array}{c}\text { Összeépíthetőség, } \\
\text { bővíthetőség }\end{array}$ & $\begin{array}{c}\text { Következtető gép jellem- } \\
\text { zői }\end{array}$ & $\begin{array}{c}\text { Beépített illeszkedés- } \\
\text { vizsgálat }\end{array}$ \\
\hline PowerLOOM & $\begin{array}{l}\text { Java alapon ösz- } \\
\text { szeépíthető, bő- } \\
\text { víthető, de saját } \\
\text { nyelvet } \\
\text { (STELLA) hasz- } \\
\text { nál }\end{array}$ & $\begin{array}{l}\text { Tudásbázisban eltárolt } \\
\text { tények és szabályok alap- } \\
\text { ján előre-, illetve hátrafelé } \\
\text { következtetést használó } \\
\text { algoritmusok vihetők fel }\end{array}$ & nincs \\
\hline OntoStudio & $\begin{array}{l}\text { plugin útján bő- } \\
\text { víthető }\end{array}$ & $\begin{array}{l}\text { Beépített F-logic követ- } \\
\text { keztető gép, } \\
\text { hozzáadott szabályszer- } \\
\text { kesztő }\end{array}$ & van \\
\hline $\begin{array}{l}\text { Protégé 3.x, } \\
\text { Protégé 4.x }\end{array}$ & $\begin{array}{l}\text { Java alapon ösz- } \\
\text { szeépíthető, } \\
\text { plugin útján bő- } \\
\text { víthető }\end{array}$ & $\begin{array}{l}\text { a hozzáillesztett plugin } \\
\text { által meghatározott kö- } \\
\text { vetkeztető rendszer (pl. } \\
\text { Jess, vagy SWRL) típusa } \\
\text { alapján }\end{array}$ & $\begin{array}{l}\text { Owl Diff plugin, ill. } \\
\text { Compare Ontologies } \\
\text { menüpont segítségével }\end{array}$ \\
\hline Kaon2 & $\begin{array}{l}\text { Java alapon ösz- } \\
\text { szeépíthető, } \\
\text { Protégé-ből elér- } \\
\text { hető }\end{array}$ & $\begin{array}{c}\text { SPARQL szintaxisra } \\
\text { építve konjunktív lekér- } \\
\text { dezéseket támogat }\end{array}$ & nincs \\
\hline
\end{tabular}

5. táblázat Automatikus illeszkedésvizsgálat

Bár az Ontostudio beépített illeszkedésvizsgálattal rendelkezik és plugin újtán bővíthető, azonban a forráskód hiánya valamint a lincenszhez való kötöttség a nyílt for- 
ráskódú programokkal szemben nehezebbé teszi a szoftver használatát - pl. a letöltő program által biztosított fájlok átalakítása, automatikus importja - az automatikus változáskövetés terén. A nyílt forráskódú programok forráskódjának javíthatósága, Java nyelven írt programmal való összeépíthetősége, pluginnal történő bővítése előrevetíti mind a dokumentumok automatikus importálásának, mind az ontológiák illeszkedésvizsgálatának a lehetőségét. Ezek közül a Protégé 3.x, illetve a 4.x rendelkezik a legszélesebb, általam igényelt funkcionalitással. Mivel a Protégé 4.x kezeli az OWL-DL-nél nagyobb kifejezőerejü OWL 2-t, ezért ezt választottam a metamodellek implementálására.

A következő lépésben a modellek adott szakterületre vonatkozó adaptálására, azaz a szakot, valamint a munkaerő-piaci igényeket leíró forrásokból kinyerhető ismeretek meta-modellbe történő öntésére került sor. Mivel ez egy prototípusos fejlesztés volt, ezért itt jegyezném meg, hogy a rendszerbe eddig a Szoftverfejlesztő munkakör, szervezeti környezete, valamint az egyes oldalakon a kapcsolódó kompetenciák lettek implementálva. A rendszer azonban tetszőlegesen bővíthető új elemekkel.

\section{IV.1.4. A Képzési Kimeneti Követelmény Ontológiára épülő szakmastruk- túra létrehozása}

A szakmastruktúra nem más, mint a Képzési Kimeneti Követelmény Ontológia specializációja a Budapesti Corvinus Egyetem Gazdaságinformatikus BSc képzésének kompetenciatartalmaira vonatkozóan. Az 1. mellékletben lévő szakleírásból is jó látszik, hogy az itt szereplő kompetenciák túl általánosak, nagy területeket foglalnak magukban, ezért az Információrendszerek Tanszék munkatársainak oktatási tapasztalataira alapozva születtek meg azok a tudáselemek, amik az ontológiában feldolgozásra kerültek (11. ábra). Azért csak a tudáselemek, mert a gazdaságinformatikus képzés során elsősorban a tudáselemek átadására helyeződik a hangsúly, valamint a kompetencia más elemeivel ellentétben a tudáselemek jól mérhetőek, ezáltal könynyebben beazonosíthatóak. Így a következő fázisban végrehajtott illeszkedésvizsgálat is erre a kompetencia-elemre fókuszált. Az ábrában pirossal vannak jelölve azok azok a tudásterületek, amelyek a szoftverfejlesztői munkakör betöltéséhez kellő tudásanyagot nyújtanak. 


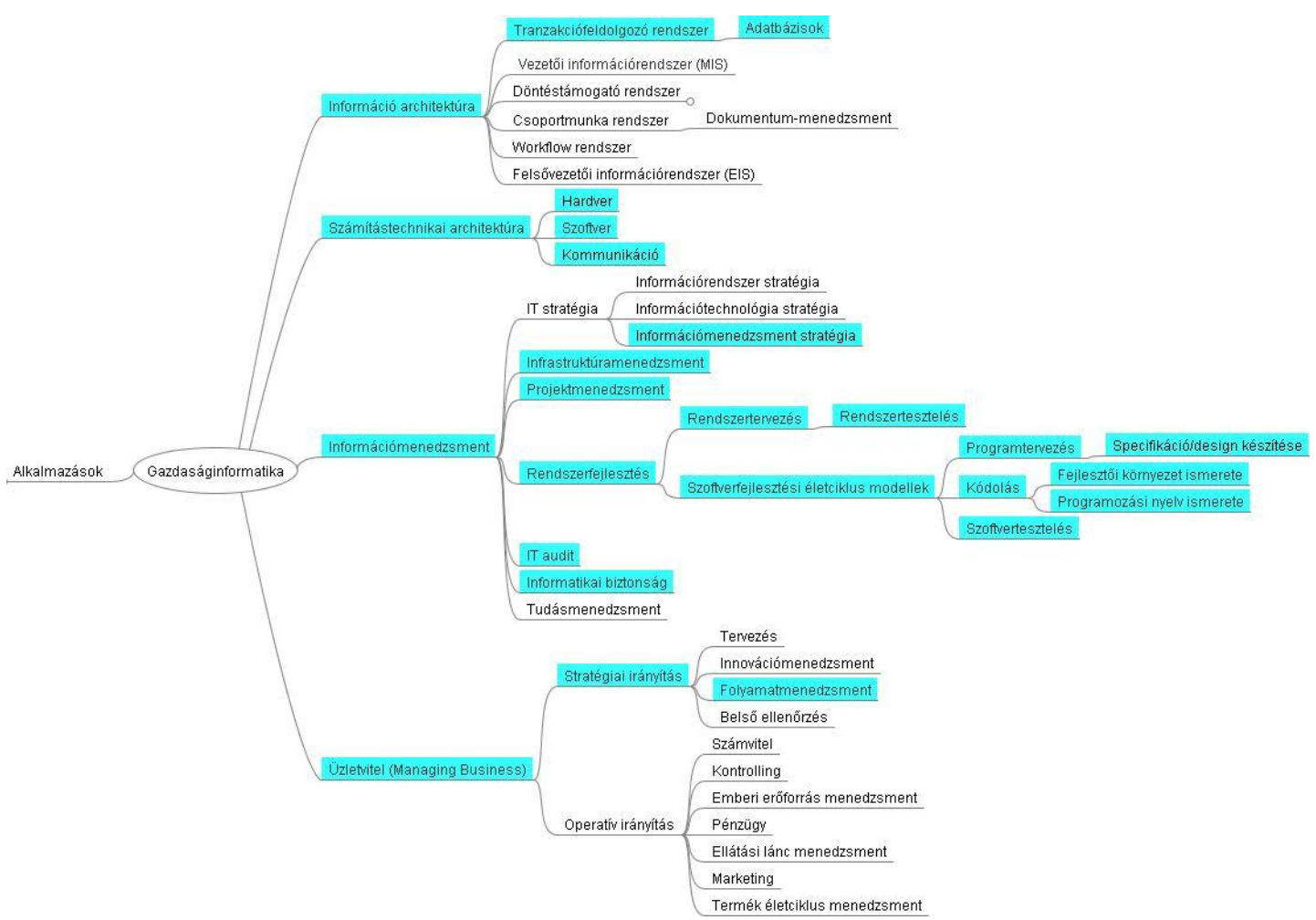

11. ábra BCE Gazdaságinformatikus BSC képzés tudáselemei

Az ontológia Protégé 4.1-ben történő implementációját, valamint az osztályok példányosítását (lsd. IV.1.5.3 fejezet) mutatja be a 12. ábra.

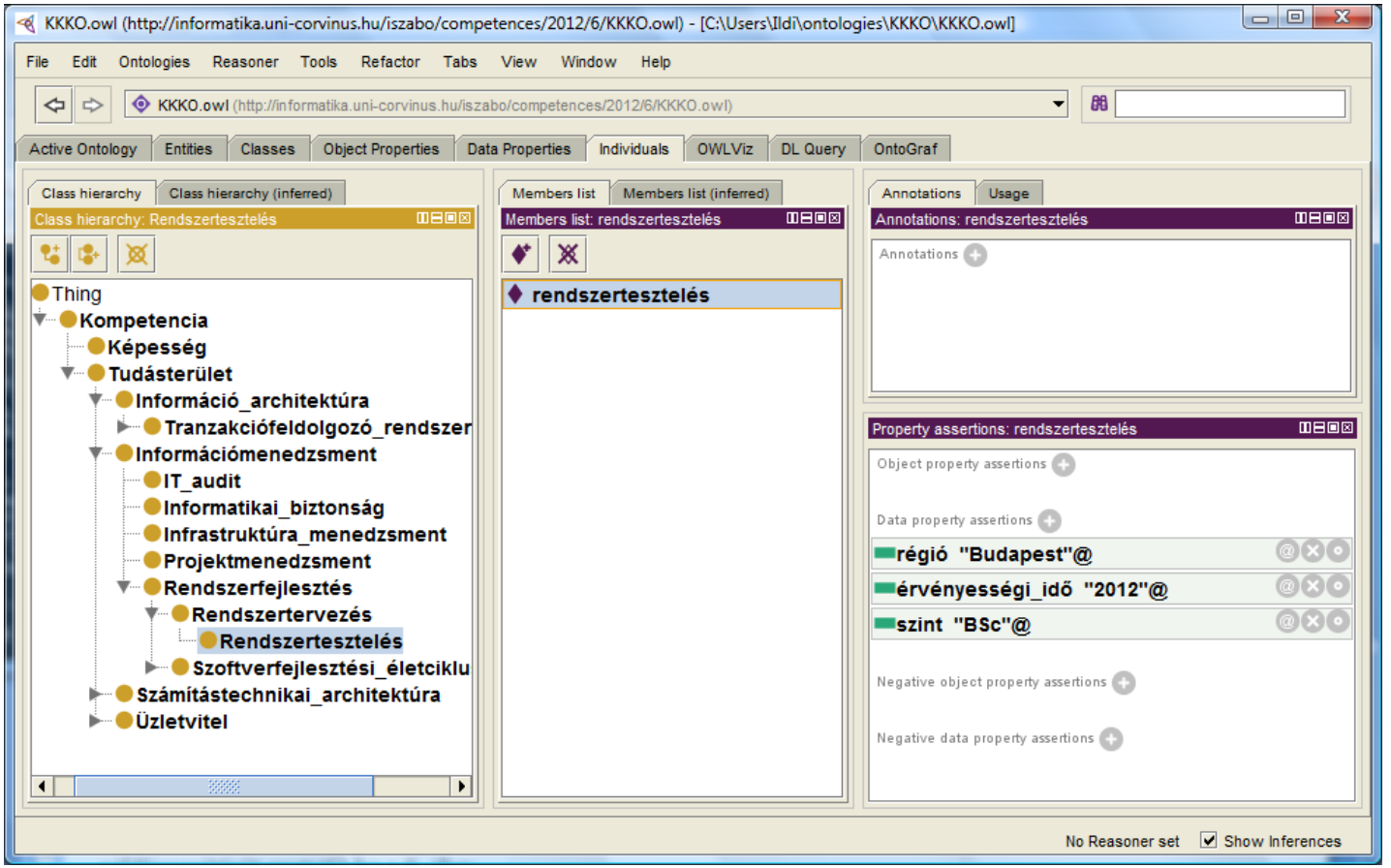

12. ábra A KKKO ontológia Protégé 4.1-ben való implementációja

Az információtechnológia fejlődése, módszertani változások stb. miatt ezek a tudáselemek évenként revízió alá esnek, azonban jelentősebb mértékben rendkívüli ese- 
mények hatására (pl. felsőoktatási reform) változnak meg, amelyek időszakos változások, vagyis nem olyan dinamikus változások, mint amelyek a munkaerőpiac keresleti oldalán zajlanak le.

\section{IV.1.5. A Munkaköri Leírás Ontológiára épülö foglalkozási struktúra lét- rehozása}

A vállalatoknak alkalmazkodniuk kell a környezetükböl érkező változásokhoz, ami a szervezeti oldalról érkező igények folyamatos kezelését vonja maga után. A foglalkozási struktúra kialakításához ezért olyan dokumentumokra van szükség, amely ezeket a változásokat megfelelően tükrözik. Erre a legalkalmasabbnak az Interneten fellelhető állásajánlatok tüntek, ugyanis a nyomtatott változattal szemben itt nincs idö-, illetve szövegkorlát a hirdetések feladására, a szerkesztő felület könnyen hozzáférhető, egyszerüen kezelhető, illetve igény szerint testreszabható hirdetéseket lehet vele létrehozni. Ahogy a Puzzle International 2011-ben (HRToborzás, 2011), valamint a DGS Global Research 2009-ben ismertetett felmérése (AllasTrend, 2009) is rámutatott a vállalatok a leggyakrabban az interneten hirdetnek. Itt jegyzem meg, hogy a közösségi portálok kezdenek egyre nagyobb szerepet játszani a munkaerötoborzásban (JobViteSRS, 2011). Így a dokumentumok forrásául Magyarország vezető állásportáljának tekintett Profession.hu portált, valamint ezen belül az IT munkakörökhöz leginkább kapcsolódó IT/Telekommunikáció csoport választottam. (2012. harmadik negyedévében már a külön létrehozott IT fejlesztés/Programozás csoportot használtam.)

Az itt fellelhetö álláshirdetésekben többnyire a következő adatokat találjuk meg:

- pozíció neve

- cégismertetö

- elvégzendö tevékenységek listája

- elvárt, illetve elönyös kompetencia elemek

- cég által biztosított előnyök

- pozíció területei

- munkavégzés helye

- jelentkezés módja.

Az állásajánlatokat megvizsgálva megállapíthatjuk, hogy a pozíciók nevei nagyon változatosak, csak a név alapján nem illeszthetők bele egyértelmúen sem a TEÁOR, 
sem az ISCO által megadott kategóriákba (ennek a vizsgálata túlnyúl a dolgozat határain, azonban elméletileg a fejleszteni kívánt rendszer módosításával megoldható). Viszont a betöltetni kívánt szerepkörre vonatkozó utalásokat tartalmaznak.

A válság első évében, azaz 2009. októberében, valamint 2010. augusztusa és szeptembere közepe között, illetve 2012. októberében letöltött IT munkakörökre vonatkozó állásajánlatokban megjelenő szerepkörök megoszlását mutatja be az alábbi táblázat, illetve a diagrammok.

\begin{tabular}{|c|c|c|c|}
\hline Szerepkör & 2009 & 2010 & 2012 \\
\hline adminisztrátor & 30 & 11 & 43 \\
\hline operátor & 19 & 15 & 15 \\
\hline fejlesztő & 135 & 182 & 252 \\
\hline menedzser & 66 & 79 & 96 \\
\hline mérnök & 70 & 104 & 107 \\
\hline konzulens & 28 & 23 & 33 \\
\hline szakértő & 41 & 39 & 75 \\
\hline elemző & 30 & 39 & 51 \\
\hline rendszergazda & 16 & 17 & 11 \\
\hline $\begin{array}{l}\text { ügyfélkapcsolati szerep- } \\
\text { kör }\end{array}$ & 61 & 86 & 105 \\
\hline technikus & 4 & 8 & 9 \\
\hline tesztelő & 29 & 40 & 52 \\
\hline architekt & 4 & 25 & 12 \\
\hline egyéb & 55 & 66 & 49 \\
\hline Eállásajánlat & 484 & 621 & 817 \\
\hline$\sum$ szerepkör & 588 & 734 & 910 \\
\hline Fejlesztői szk. aránya & $23.0 \%$ & $24.8 \%$ & $27.7 \%$ \\
\hline
\end{tabular}

6. táblázat A szerepkörök vizsgált időszakban való abszolút megoszlása 


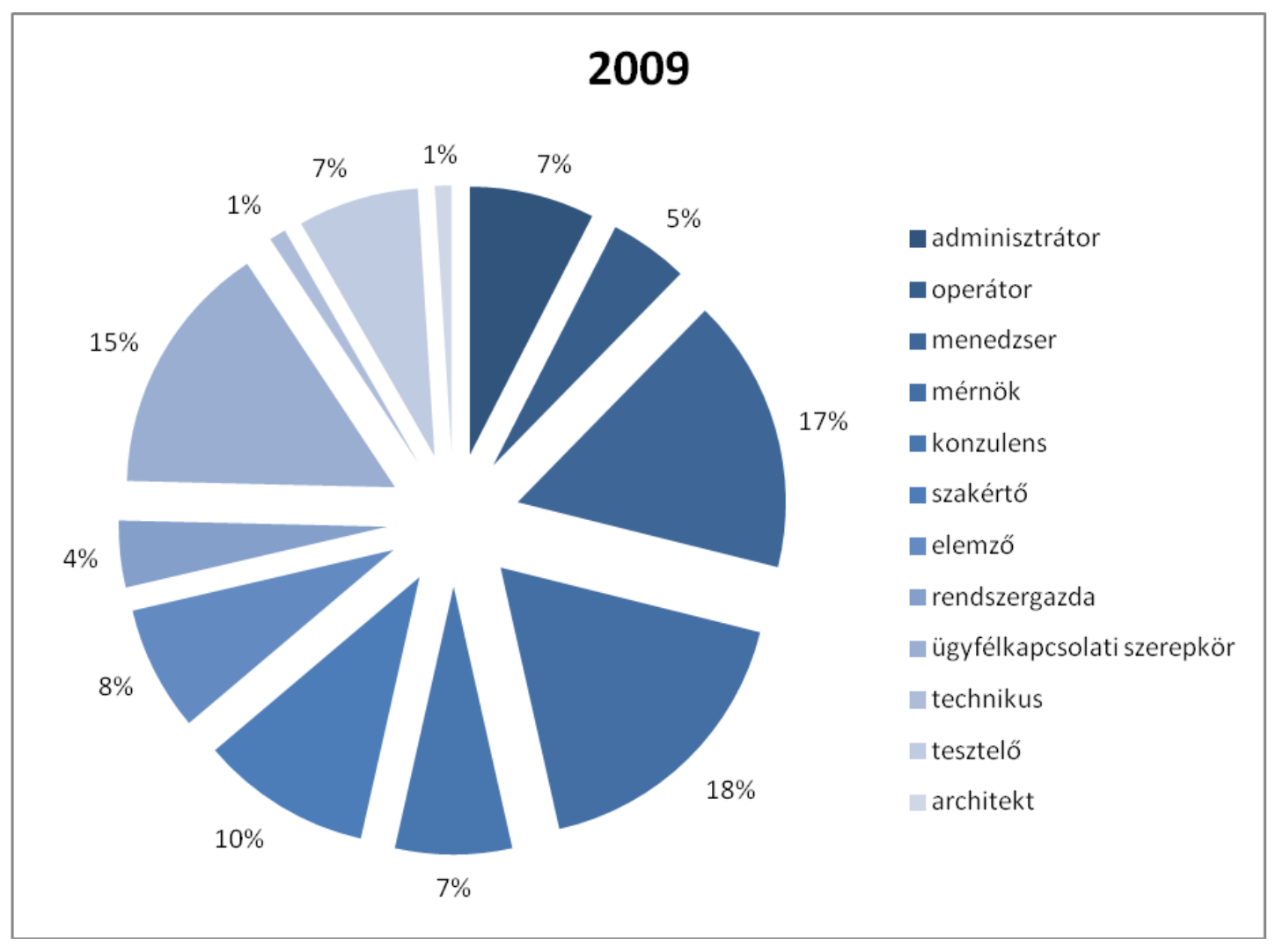

13. ábra 2009. októberében igényelt szerepkörök

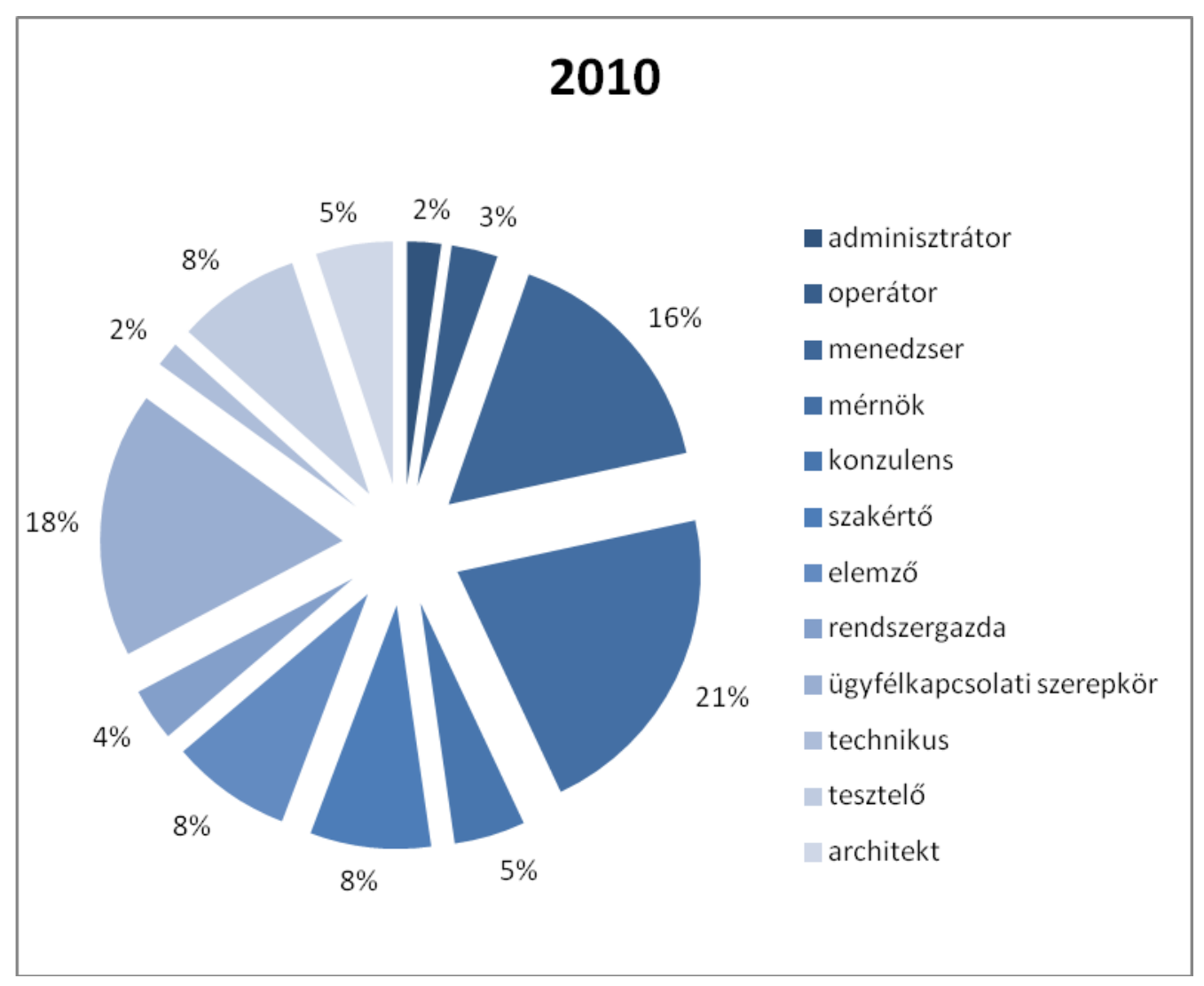

14. ábra 2010. augusztus és szeptember közepe között igényelt szerepkörök 


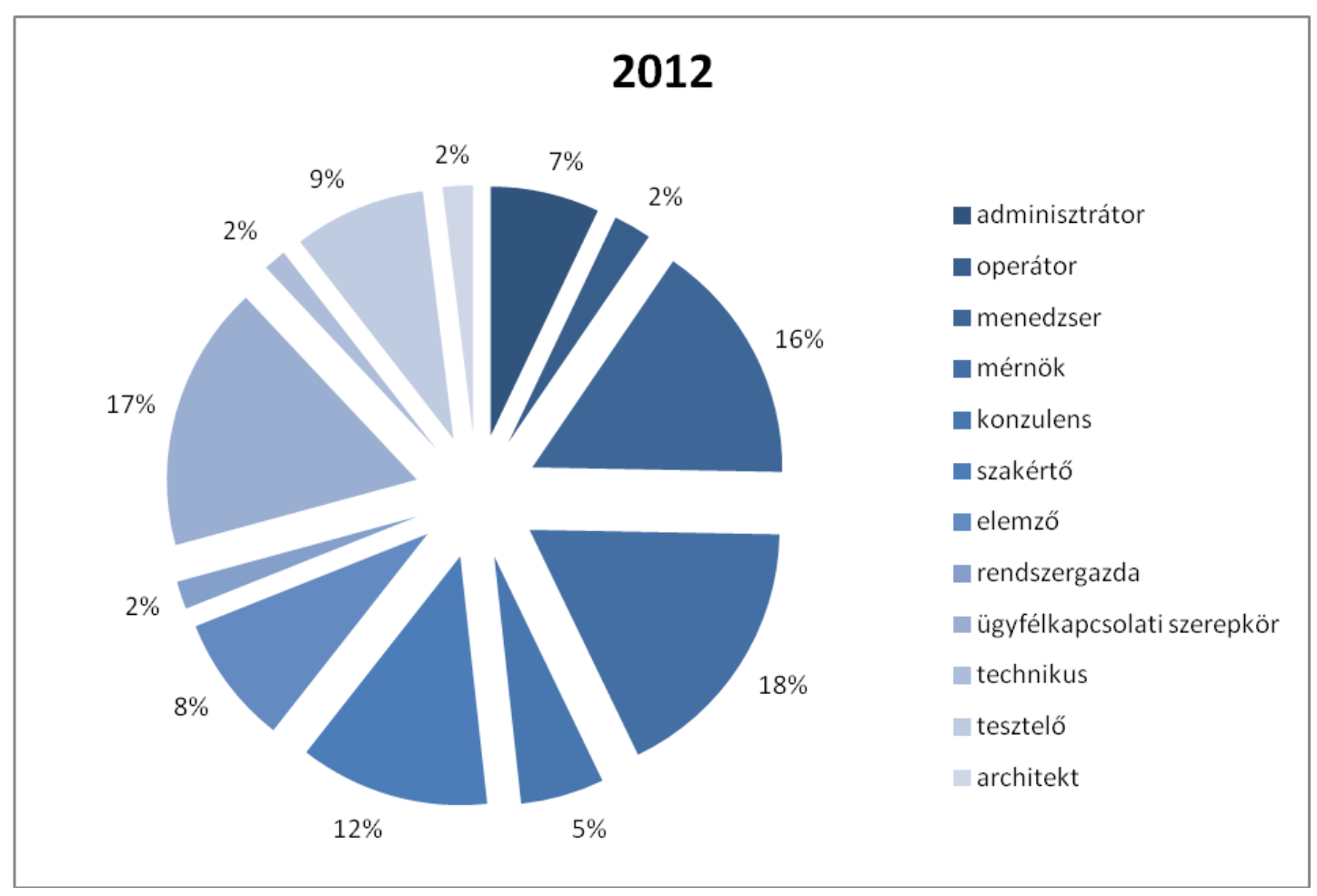

15. ábra 2012. októberében igényelt szerepkörök

A táblázatból jól látszik, hogy a fejlesztői szerepkörök adják az összes szerepkör negyedét. Illetve egy munkakör több szerepkört is takarhat, ugyanis több szerepkört sikerült beazonosítani, mint munkakört. A többi szerepkörre vonatkozóan megállapíthatjuk, hogy 2009. és 2012. megfelelő időszakában az arányuk láthatóan csak 1\%3\%-os eltérést mutat. A kép árnyalása végett került bemutatásra a 2010-es megoszlás, amely csak az adminisztrátor, illetve az architekt kategóriában mutat ennél nagyobb arányú eltérést. Azaz megállapítható, hogy ebben a tekintetben keveset mozdult a piac.

Mindemellett az állásajánlatokban szereplő információk nagyon képlékenyek, hiszen nem igazodnak egy előre megadott standard leíráshoz. Például a Szoftverfejlesztő pozíciónál egyes esetekben a tapasztalat mélysége (pl. junior, expert stb), valamint az alkalmazni kívánt programozási nyelv (Java/JEE stb.) is megadásra kerül, ami jelentősen kibővíti a munkaköri repertoárt. Az egyes szakmák - pl. az IT is - elindultak a specializáció útján, ami ahhoz vezetett, hogy az ugyanahhoz a szerepkörhöz tartozó feladatok eltérhetnek, ami a stabil munkaköri határok elmosódását (Lawler, 1994) vonja maga után. 
Nemcsak a pozíciók változatos elnevezését nehézkes standard módon leírni, de a weboldalak kezelése sem volt egyszerü. Ugyanis a Profession.hu XHTML formátumban tárolja a hirdetéseket, és a html-tagek csak elvétve utalnak a köztük szereplő információk szemantikai tartalmára, ezért a meta-modell bővítéséhez szükség volt ezek feldolgozhatóbb, átláthatóbb formára hozására.

\section{IV.1.5.1. A meta-modell implementálása}

Ebben a fázisban kiindulási alapként a prototípus céljaként megfogalmazott szoftverfejlesztői munkakör és a hozzá kapcsolódó alábbi osztályok kerültek implementálásra (7. táblázat, illetve 16. ábra).

\begin{tabular}{|l|l|}
\hline \multicolumn{1}{|c|}{ Osztály } & \multicolumn{1}{c|}{ Alosztály } \\
\hline Pozíció & Szoftverfejlesztő \\
\hline Szerepkör & Fejlesztői szerepkör \\
\hline Feladat & $\begin{array}{l}\text { Szoftverfolyamat tervezése } \\
\text { Specifikáció készítése } \\
\text { Program kódolása } \\
\end{array}$ \\
& $\begin{array}{l}\text { Program tesztelése } \\
\text { Program dokumentálása } \\
\end{array}$ \\
& $\begin{array}{l}\text { Hibakezelés } \\
\text { Rendszerintegráció } \\
\text { Együttmüködés }\end{array}$ \\
\hline
\end{tabular}

7. táblázat Szoftverfejlesztői munkakörhöz kapcsolódó osztályok 


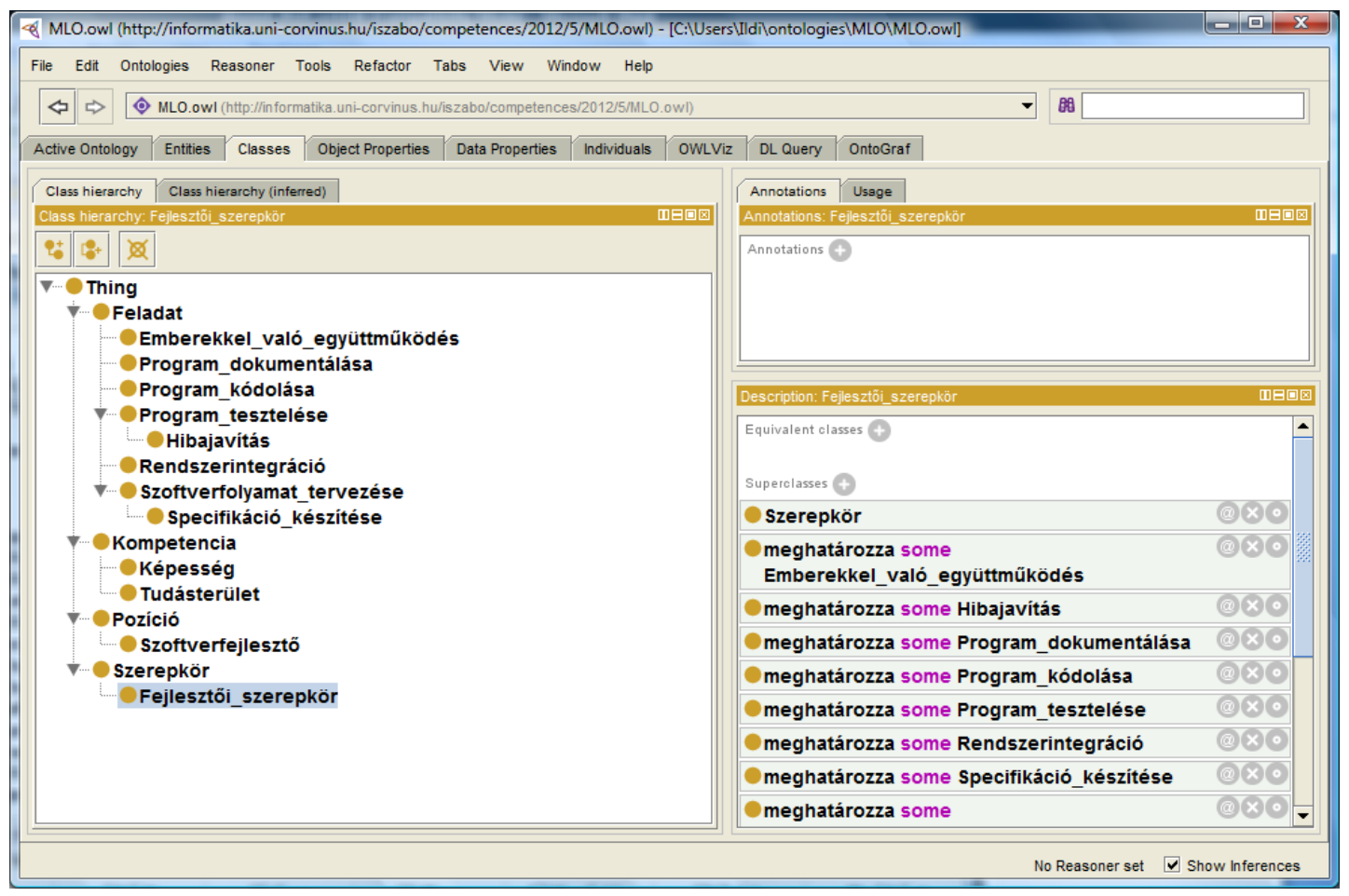

16. ábra Meta-modell Protégé 4.1-ben

\section{IV.1.5.2. A meta-modell bövítése}

A további osztályokkal való bővítés a Profession.hu oldal IT/Telekommunikáció kategóriájából legyüjtött állásajánlatok tartalmán alapult, amelyek automatikus letöltéséért felelős crawler ${ }^{19}$ kidolgozására két lehetőség kínálkozott. Vagy a Google Spreadsheets ImportXML("URL";"query") függvényének segítségével kigyüjtöm az egyes tagek közötti szövegeket, vagy JAVA programozási nyelv java.io csomagja segítségével letöltöm az összes fájlt. Az első változat mellett szólt az egyszerüsége, azonban a Google Spreadsheets az ékezetes betüket nem kezeli, ezért a későbbi, magyar nyelvü szövegfeldolgozást nem lehetett volna megvalósítani vele. Ezért, valamint a más programokkal történő egyszerübb összeépíthetőség miatt döntöttem az utóbbi változat alkalmazása mellett.

A JAVA programozási nyelvben írt program 2009 óta kisebb-nagyobb kihagyásokkal folyamatosan gyüjti az állásajánlatokat. Egy excel fájlban tárolja a hirdetések linkjét, a pozíció elnevezését, a hirdető cég nevét, a munkavégzés helyét, a hirdetés időpontját, majd letölti az aktuális állásajánlat kollekciót is. Egy gyüjtés körülbelül egy havi hirdetést jelent.

\footnotetext{
${ }^{19}$ Linkeket követő internetes böngészőprogram.
} 
A Profession.hu IT/Telekommunikáció kategóriájában a 2010. december 27. és 2011. április 10. között - közel egy negyedéves gyüjteménynek tekinthető - állásajánlatok a következő jellemzőkkel bírtak:

- több hirdetési szöveg teljesen egyforma pl. csak a testreszabhatóság miatt a formát kialakító tagek miatt különböznek.

- a fájlok XHTML formátumban vannak, emiatt a testreszabási lehetőségek, a formázási HTML tagek, valamint a szöveg szemantikai tartalmára utaló kevés HTML tag miatt a fájlok csak félig strukturáltak.

- a fájlok 83\%-ában a hirdetés szövege a <!--hirdetes start--> és <!--hirdetes stop--> tagek közé van elhelyezve.

- a fájlokban felfedezhetők egyforma blokkok, vagy azok szinonímái pl. feladatok:, elvárások: (követelmények: ), munkavégzés helye: stb, amelyek a ,„:" segítségével többnyire beazonosíthatóak.

- az elvárások blokk tartalma egyes esetekben elnagyolt, vagy kevés információt tartalmaz.

A problémák áthidalására egy olyan szövegfeldolgozó programra volt szükség, amely az XHTML fájlokból JAVA programozási nyelven feldolgozható outputot készít. Az így nyert outputnak mindemellett még a következő kritériumoknak kellett megfelelnie:

- a prototípusos fejlesztés miatt magyar nyelvü szoftverfejlesztői állásajánlatokból kellett felépülnie.

- duplikátumokat lehetőleg ne tartalmazzon. Ennek elsősorban akkor van jelentősége, ha a munkaerőpiac két oldalának összehasonlítása során az is mérésre kerül, hogy az egyes kompetenciákra mekkora fokú igény jelentkezik.

- olyan adatokat kell tartalmaznia, amivel a meta-modellek új alosztályokkal bővíthetők, amik az aktuális igények alapján validálhatók. A jelölttel szembeni elvárások elnagyoltan jelennek meg, ami az összehasonlításhoz nem tud kellö alapot biztosítani. Azonban az elvégzendő feladatok elég részletesek, ezért a Feladatok: blokknak az Elvárások: blokk mellett mindenképpen meg kell jelennie.

A feldolgozási folyamatot mutatja be a 16 . ábra. 


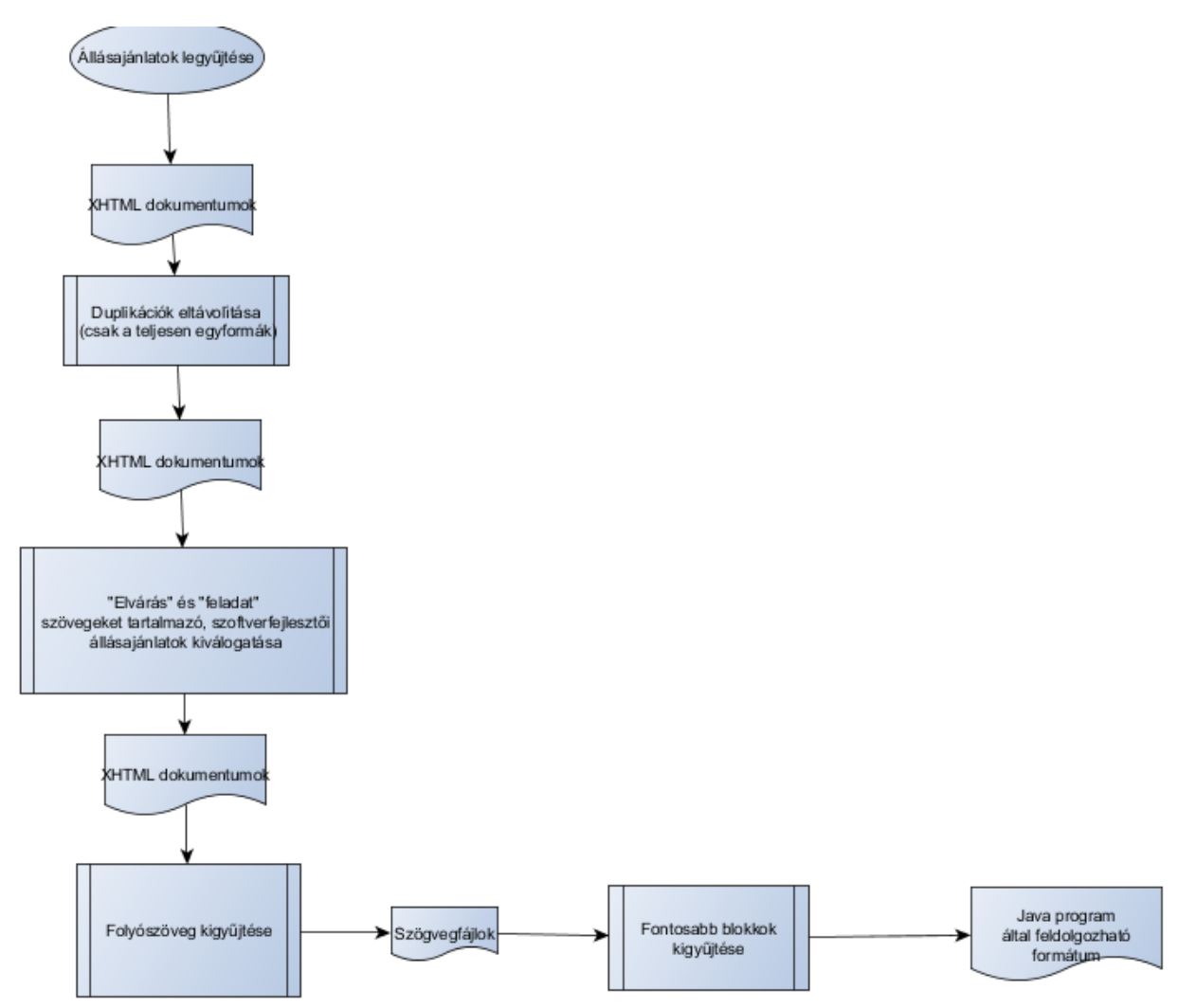

17. ábra XHTML fájl feldolgozásának folyamata

A duplikátumok ${ }^{20}$, valamint az Elvárás:, Feladatok: blokk-kal rendelkező Szoftverfejlesztő munkakörhöz kapcsolódó állásajánlatok kiszürésére DOS Batch programot használtam. A folyószöveg kigyüjtését, a HTML tagek teljes kitörlését segítették a Gsar, illetve Gawk programok. A fontosabb blokkok beazonosítását egy JAVA program végezte, amely egy korábbi elképzelés szerint XML fájlt készített volna (Szabó, 2011), azonban az apache.poi library segítségével a JAVA excel fájlt is tud kezelni. Így a feladatok átláthatóbb formában jelenhettek meg.

Az előbb említett, közel negyedéves, 2787 fájlból álló gyüjtés szolgált a meta-modell új osztályokkal való feltöltésére. Ebböl 183 duplikátum lett törölve. Elvárások: blokkot tartalmazott 1307 fájl, míg ezeken belül 544 fájlban szerepelt Feladatok: blokk ${ }^{21}$. Az utolsó szürés után 323 olyan fájlom maradt, amely tartalmazta a fejleszt szót, amivel fejlesztői szerepkörre utalt. Viszont csak 280 fájlban volt a feladat: blokk a $<$ hirdetés start $>$ és a $<$ hirdetés stop $>$ blokkon belül. Azaz az eredeti kollekció 10,76\%-át tudtam csak feldolgozni. Azaz jelentős információveszteséget szenvedtem

\footnotetext{
${ }^{20}$ Egyelöre csak a teljesen egyforma fájlokat tekinti duplikátumoknak.

${ }^{21}$ Mivel a feldolgozó program az elvárások: és a feladatok: kulcsszavakat kereste, ami a folyószövegben más összefüggésben is előfordulhatott, ezért ezek maximális értéknek tekinthetők inkább.
} 
el amiatt, hogy a portál félig-strukturált formátumban publikálja az adatait, valamint amiatt, hogy a szinonímákat nem kezeli a rendszer.

A scriptek és a JAVA program eredményeként kapott Excel tábla 280 sora összesen 1414 feladatot, illetve feladatcsoportot tartalmazott, ugyanis a hirdetők sok esetben nem sorolták fel tételesen a feladatokat, csak egy általános leírást adtak róluk.

Ilyen outputot használtam fel egyrészt a meta-modellek új osztályokkal történő bővítésére, másrészt az éppen aktuális állásajánlatok feldolgozására, azaz az osztályokhoz egyedek rendelésére.

\section{IV.1.5.2.1. Ontológiai tanulás}

Az ontológiai tanulás (ontology learning) terület foglalkozik szakterületi ontológia különböző forrásokból történő építésével természetes nyelvű feldolgozó, illetve gépi tanulási technikák segítségével (Haase-Völker, 2008 pp.1). A természetes nyelvi feldolgozás technikái alapján megkülönböztethetünk statisztikai alapú, szabály alapú, illetve hibrid ontológiai tanulást (Zhou, 2007). Felismerhető, hogy az állásajánlatok feladatleírásaiban a hirdetők kedvelik a birtokos szerkezet használatát pl. alkalmazás tervezése, fejlesztések tesztelése. Ezért a mintázaton alapuló feldolgozási technikát választottam. A mintázatok célja, hogy a lehető legjobban körülírja, megfogalmazza az egyes ontológiai osztályok mögöttes tartalmát, így megtalálva a lehető legtöbb kapcsolatba hozható kifejezést.

A mintázatok két csoportot alkottak, annak alapján, hogy az előbb említett birtokos szerkezetből indultam-e ki, vagy a bővíteni kívánt osztályt jellemző szót körülvevő környezetéből. Az első esetben a Prológ programozási nyelvből ismert nyitott kérdéseket választottam reprezentációul, amelyek (központi fogalom, vonzat) formában adhatók meg. A vonzatok többnyire -nak, -nek -re, vagy többes számra végződnek. P1. A Szoftverfolyamat tervezése feladat központi elemét a tervezés képezi, ezért a birtokos szerkezetben megfogalmazott mintázata a (tervezése, minek).

A feladatleírások feldolgozása során először minden osztálynak megadtam vagy egy jellemző szavát, vagy egy, az őt leíró nyitott kérdését, majd a szövegben a központi fogalom szótövét, illetve a vonzat jellemző karaktereit kerestem. Feltételeztem, hogy az egymással szorosan kapcsolatban álló fogalmak többnyire nem esnek egymástól nagyon messze, így maximum egy szónyi, azaz két szóköznyi távolságot engedtem meg a központi fogalom és a vonzat között. Az ontológiába alosztályként a központi 
fogalom és annak állásajánlatból nyert vonzata került. A jellemző szó a környezetében elöforduló szavakkal egyetemben került be osztályként a rendszerbe. A szövegfeldolgozás alapjául szolgáló elemeket részben bemutatja a 8. táblázat. (A birtokos szerkezetek más nyelvtani szerkezetekkel való bővítése végett került be a Hasonul-e oszlop.)

\begin{tabular}{|l|l|l|l|}
\hline Osztály & $\begin{array}{l}\text { Központi fogalom } \\
\text { szótöve }\end{array}$ & Hasonul-e & $\begin{array}{l}\text { Vonzatok jellemzö } \\
\text { betüi }\end{array}$ \\
\hline Szoftverfolyamat_tervezése & tervezés & nem & ak ,ek ,ik ,ok ,uk \\
\hline Szoftverfolyamat_tervezése & tervezés & X & X \\
\hline Specifikáció_készítése & specifikáció & X & X \\
\hline Specifikáció_készítése & specifikál & nem & ak ,ek ,ik ,ok ,uk \\
\hline Program_kódolása & fejleszt & nem & program \\
\hline Program_kódolása & kódol & nem & ak ,ek ,ik ,ok ,uk \\
\hline Program_kódolása & programozási nyelv & X & X \\
\hline Program_tesztelése & tesztelése & nem & ak ,ek ,ik ,ok ,uk \\
\hline Program_dokumentálása & dokumentál & nem & ak ,ek ,ik ,ok ,uk \\
\hline Program_tesztelése & tesztelési & X & X \\
\hline Program_tesztelése & tesztelő & X & X \\
\hline Program_dokumentálása & dokumentáció & X & X \\
\hline Hibakezelés & hiba & X & X \\
\hline Rendszerintegráció & integrál & nem & ak ,ek ,ik ,ok ,uk \\
\hline Rendszerintegráció & integráció & X & X \\
\hline Együttmúködés & kapcsolattartás & nem & al, el \\
\hline Együttmüködés & együttmüköd & nem & al, el \\
\hline
\end{tabular}

8. táblázat Alkalmazott szótár

A JAVA program az előző táblázatban szereplő nyitott kérdések az állásajánlatok feladatleírásait tartalmazó excel fájlban szereplő 1414 feladat, vagy feladatcsoportból 263-at dolgozott fel, ami így 18,6\%-os feldolgozottságot jelentett. Ezt az alacsony értéket az is magyarázza, hogy a fejlesztésre való szürés nem volt elég pontos, mivel más szerepkörhöz kapcsolódó ajánlatok is megjelentek: 


\begin{tabular}{|l|r|r|}
\hline & Összesen & Talált \\
\hline üzemeltet & 98 & 12 \\
\hline projekt & 120 & 14 \\
\hline rendszergazda & 11 & 0 \\
\hline karbantart & 63 & 5 \\
\hline értékesít & 11 & 0 \\
\hline
\end{tabular}

Mindemellett a táblázat tovább bővíthető. Azonban a jobb találati arány elérése végett olyan szavakra volt szükség, amely valóban jellemezte az adott osztályt és a szövegben is elöfordult. Ehhez nyújtott segítséget a SPSS Clementine szövegbányászati eszköz, amely meg tudta határozni magyar szavaknak az állásajánlatokban való gyakoriságát, ezzel is hozzájárulva a pontosabb találatok eléréséhez (3. melléklet).

Az SPSS Celementine mellett szólt, hogy az oktatásban, vagy más projektekben használt - Gate, RapidMiner, SAS Textminer - szövegbányászati eszközökkel szemben már rendelkezett egy beépített magyar szótárral, így az outputként megadott táblázata nemcsak szótöveket, hanem teljes magyar szavakat tartalmazott. Bár nem nyílt forráskódú program, azonban a rendszer fejlesztése során csak ebben a fázisban votl használva, ezért a licenszszerződés nem jelentett hosszú távú függőséget. A fent említett összes állásajánlatban előforduló leggyakoribb igéket a 4. melléket tartalmazza. Illetve tovább bővítettem még a kifejezéseket az igényelt programozási nyelvek (Java, C++ stb. ), valamint az adatbázissal kapcsolatos feladatok körével is. Ennek alapján az alábbi táblázat mutat be olyan szavakat, amelyeket még felvittem a rendszerbe, s ezáltal javult a találati arány. Viszont az oktatás felvétele már új feladat, a Belső képzés felvételét is magával vonta.

\begin{tabular}{|l|r|r|}
\hline & Összesen & Talált \\
\hline folyamat & 138 & 21 \\
\hline koordinál & 25 & 5 \\
\hline oktat & 28 & 4 \\
\hline
\end{tabular}

10. táblázat Fejlesztői szerepkörhöz kapcsolódó újabb feladatok

Ezen új nyitott kérdések, szavak használatával 466 feladat került feldolgozásra, ami a teljes minta 33\%-a. Láthatóan a nagyobb gyakoriságú szavak hozzáadásával a találati arány növelhető, már csak az volt a kérdés, hogy mindez mennyire pontos találatokat takart. 
Az új osztályokkal bővült Protégé ontológiát mutatja be a következő ábra:

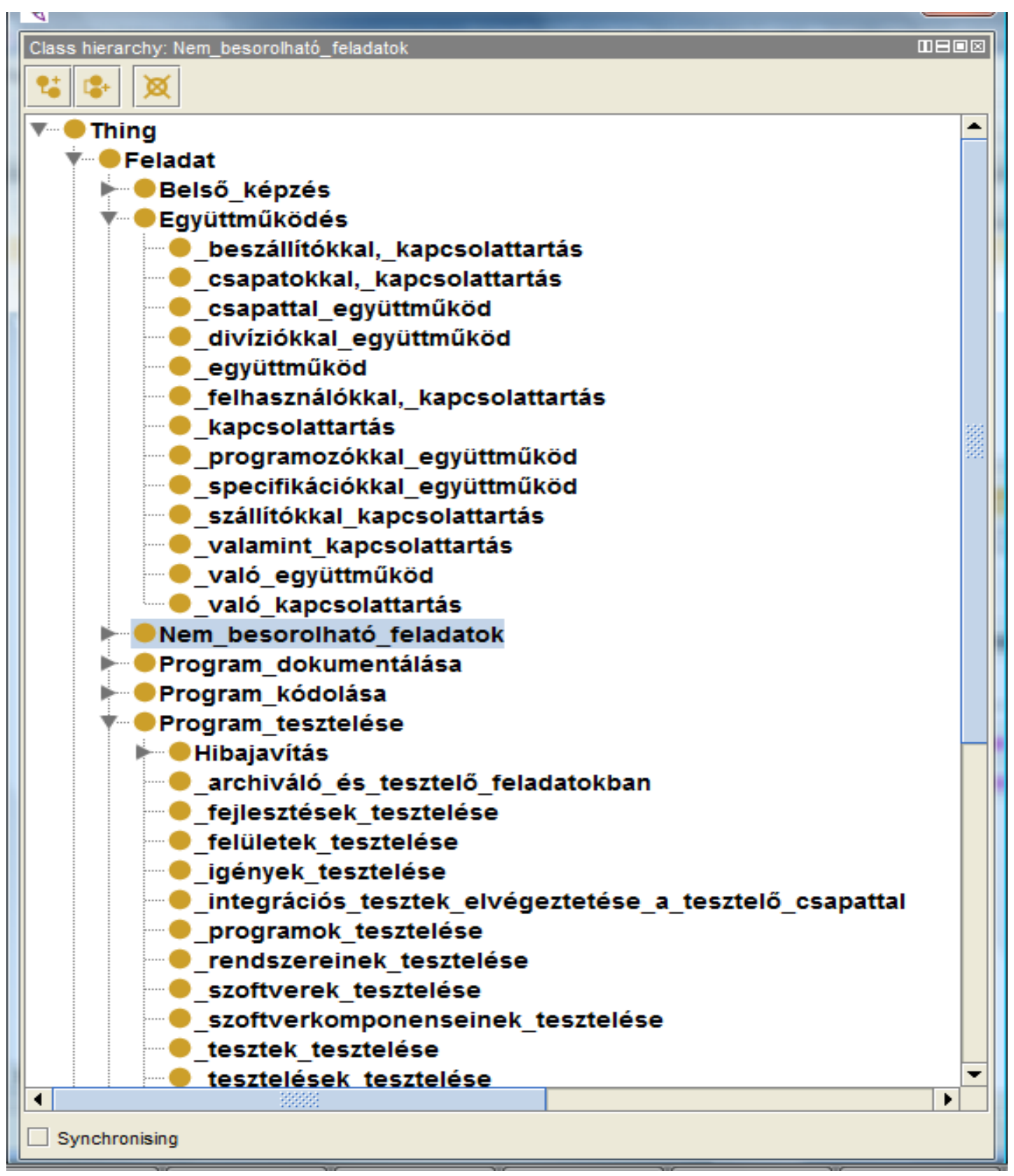

18. ábra Új osztályokkal módosított Protégé ontológia

Az algoritmus az eredeti 18 osztályt (a Protégé meta-osztályát :Thing, valamint a Belső képzés osztályt is beleértve) összesen összesen 405 alosztállyal (lsd. 4. melléklet) bővítette ki.

A Protégé-ben összesen 420 darab alosztály kapcsolat született, amiből 13 osztálynak 2 szülőosztálya volt, míg 1 osztálynak 3 szülőosztálya volt, azaz tizenöt kapcsolattal több született, mint ahány alosztály létrejött. A struktúra revíziója során azok az osz- 
tályok kerültek törlésre, amelyek elnevezése nem állt összhangban a tartalommal, és azok lettek átmozgatva, amelyek jó találatok, csak rossz osztályba lettek besorolva (11. táblázat).

\begin{tabular}{|l|c|c|c|c|c|}
\hline & $\begin{array}{c}\text { Alosztályok } \\
\text { száma }\end{array}$ & $\begin{array}{c}\text { Máshova is } \\
\text { tartozik }\end{array}$ & Törölt & Mozgatott & $\begin{array}{c}\text { Mozgatási } \\
\text { arány }\end{array}$ \\
\hline Belsö képzés & 21 & 1 & 1 & 16 & $76.2 \%$ \\
\hline $\begin{array}{l}\text { Szoftverfolyamat } \\
\text { tervezése }\end{array}$ & 208 & $11(1)$ & 11 & 74 & $35.6 \%$ \\
\hline $\begin{array}{l}\text { Specifikáció készíté- } \\
\text { se }\end{array}$ & 50 & 4 & 7 & 5 & $10.0 \%$ \\
\hline Program kódolása & 36 & 4 & 6 & 4 & $11.1 \%$ \\
\hline Program tesztelése & 22 & $2(1)$ & 3 & 1 & $4.5 \%$ \\
\hline $\begin{array}{l}\text { Program dokumentá- } \\
\text { lása }\end{array}$ & 28 & $1(1)$ & 2 & 6 & $21.4 \%$ \\
\hline Hibakezelés & 25 & 0 & 1 & 7 & $28.0 \%$ \\
\hline Rendszerintegráció & 12 & 3 & 0 & 1 & $8.3 \%$ \\
\hline Együttmüködés & 18 & 0 & 7 & 2 & $11.1 \%$ \\
\hline \multicolumn{1}{|c|}{ Összesen } & 420 & $1->3 ; 13->2$ & 38 & 116 & $27.6 \%$ \\
\hline
\end{tabular}

11. táblázat A besorolt alosztályok értékelése

A táblázatból kiderül, hogy az algoritmus jól müködik abban a tekintetben, hogy a használt nyitott kérdés, vagy a jellemző szó környezete 91\%-ban értelemszerüen jellemzi a mögötte lévő feladatot. Azonban még a jellemző kifejezések meghatározásában több kategória esetében is pontosításra szorul. A Belső képzésnél a feladatok 76.2\%-a külső felhasználók oktatásához kapcsolódott. A Szofverfolyamat tervezésénél még bekerültek projektek tervezési, adatbázis üzemeltetési, valamint stratégiai tervezési feladatok is. A Hibakezelés esetében az üzemeltetésen, illetve ügyfélszolgálaton felmerült hibák kezelése jelent meg. A Program dokumentálásánál pedig a projektek dokumentációjának elkészítése került be nem a fejlesztői szerepkörhöz tartozó feladatként. Megfigyelhető, hogy ezeknél a feladatoknál vagy teljesen, vagy jelentős arányban a jellemző szavak köre volt megadva a mintakereséshez, amit a jövőben érdemes nyitott kérdésekkel kibővíteni. 
A tudáselemmekel való bővítés előzményeként az összetartozó alosztályok újabb osztályokba lettek rendezve, illetve a nem kifejezetten fejlesztői szerepkörhöz kapcsolódó feladatok bekerültek a Nem besorolható feladatok osztályába. Az állásajánlatokból nyert osztályok kitörlése után kapott struktúrához (19. ábra) kerültek hozzárendelésre a tudáselemek.

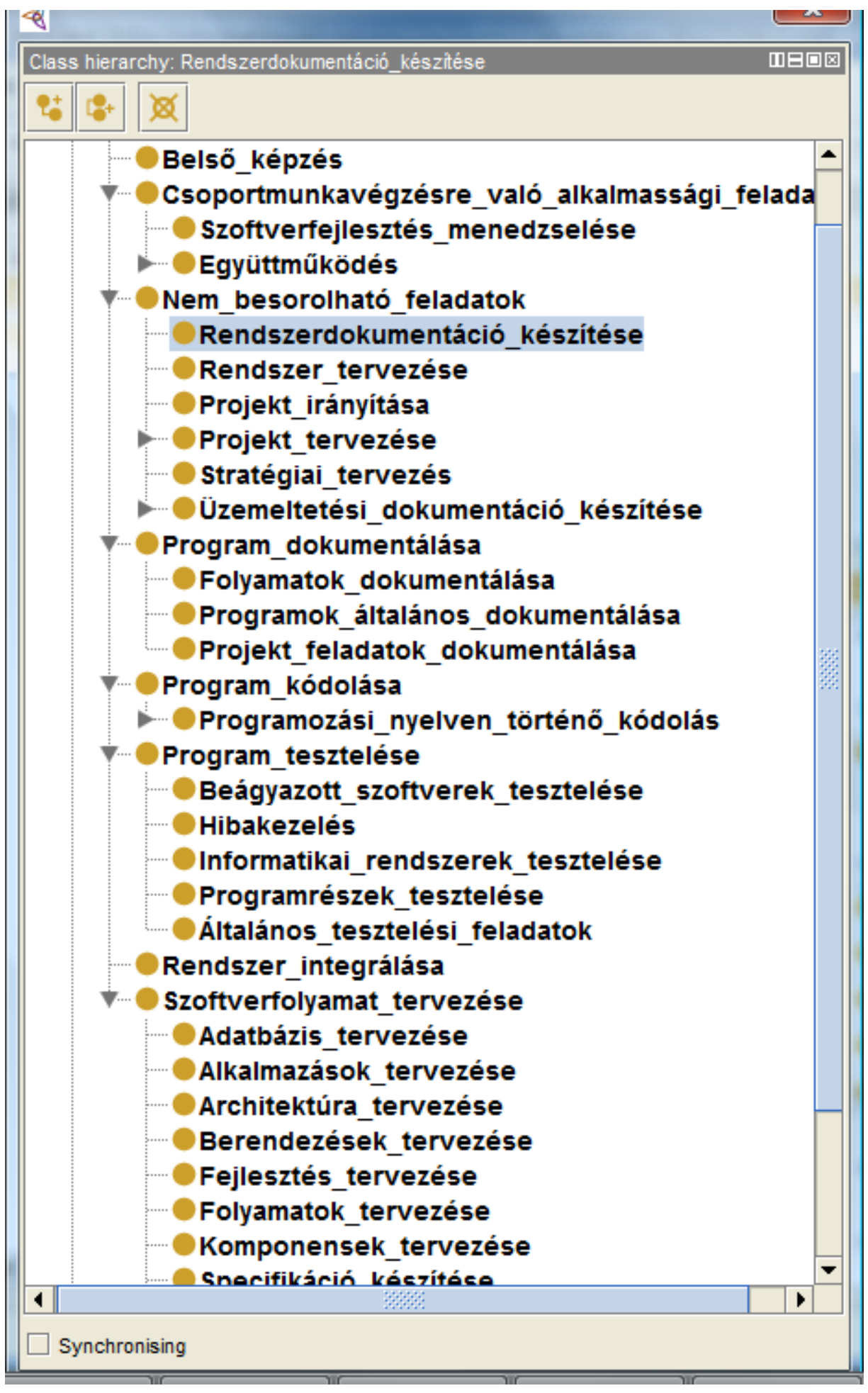

19. ábra MLO Feladat osztályának hierarchiája 


\section{IV.1.5.2.2. A Tudásterület osztály bövítése}

A tudáselemek felvitelére két lehetőség kínálkozott. Vagy az állásajánlatok Elvárások: blokkjából vesszük ki azokat és illesztjük be az ontológiába, vagy egy olyan dokumentumból (esetünkben a TOGAF-ból) vesszük ki azokat, amely tükrözi az általános iparági elvárásokat. Mivel a tapasztalat azt mutatta, hogy az állásajánlatokban megfogalmazott elvárások nem egy standard szókészletre épülnek, időnként nem túl informatívak, ezért inkább a második változat mellett döntöttünk. Az állásajánlatokban szereplő elvárásokat fel lehet használni az így kijelölt tudáselemek aktuális validálására, azonban ez a funkció a mostani rendszerbe nem került be. Ellenben a jövőben bővíthetővé válik vele, ugyanis a rendszer olyan feladatokból építkezett, amelyekhez elvárások is kapcsolódtak.

A The Open Group Architecture Framework (TOGAF) egy olyan nyílt keretrendszer, amely a vállalati architektúra kialakítására oly módon kínál eszközöket és módszereket, hogy azt több különböző nézőpontból, négy nagyobb tárgyterületet (üzlet, adat, alkalmazás és technológia) érintve szemléli. Az architektúra kialakításáért felelős személynek, az előbb említett tárgykörökre vonatkozóan alakították ki a szerepköreit. Mivel a rendszer- és szoftverfejlesztőknek leginkább az alkalmazás architektúra kialakításában van szerepük, ezért a modellbe az ehhez a szerepkörhöz kapcsolódó képességek, tudáselemek kerültek be. (A szervezet a The Open Group Certified Architect Program keretén belül kínál minősített képzéseket az IT, vállalati és üzleti architektúrákat kialakító személyek tudásának, képességeinek és gyakorlatának fejlesztésére és értékelésére (TogafCA, 2012).)

Maga a TOGAF az általános képességek mellett elöírja az alábbi tárgykörökhöz kapcsolódó gyakorlati képességek, tudások alkalmazását is: üzletvitel, vállalati architektúra kialakítása, program-, és projektmenedzseri feladatok, információtechnológia, illetve a jogi környezet. Az egyes szerepkörökhöz kapcsolódóan négyszintű skálán mérik az egyes ismeretek, képességek alkalmazási igényét. Az alábbi táblázat tartalmazza a hármas, illetve a négyes szintü ismereteket ${ }^{22}$, képességeket, azaz a tárgyterületről való részletes ismereteket, szakmai tanácsokat, iránymutatások nyújtásához szükséges képességeket, illetve ezek gyakorlati területeken való kiterjedt és részletes alkalmazását (OpenGroup, 2009:694-699). (A zárójelekben csoportosítottam egy adott tudásterülethez tartozó ismereteket.)

\footnotetext{
${ }^{22}$ Félkövérrel jelölt szövegek.
} 


\begin{tabular}{|c|c|c|}
\hline Tárgyterület & Kompetencia & $\begin{array}{c}\text { Kompetencia } \\
\text { típusa }\end{array}$ \\
\hline \multirow{2}{*}{$\begin{array}{c}\text { Általános képes- } \\
\text { ség }\end{array}$} & $\begin{array}{l}\text { vezetői képesség, csapatmunka, interperszo- } \\
\text { nális képesség, logikus gondolkodás, szóbeli } \\
\text { és írásbeli kommunikáció }\end{array}$ & Képesség \\
\hline & $\begin{array}{l}\text { projekt kommunikációs tervezéséhez } \\
\text { (stakeholder management), } \\
\text { kockázatkezeléshez kapcsolódó ismeretek }\end{array}$ & Tudás \\
\hline Üzletvitel & $\begin{array}{l}\text { business casek, forgatókönyvek, üzleti fo- } \\
\text { lyamatok, funkciók, valamint üzleti metri- } \\
\text { kák kezeléséhez kapcsolódó ismeretek } \\
\text { stratégiai tervezés (vízió, stratégiai tervek, } \\
\text { költségvetés, vállalati kultúra) kialakításához } \\
\text { szükséges módszerek ismerete }\end{array}$ & Tudás \\
\hline $\begin{array}{l}\text { Vállalati architek- } \\
\text { túra kialakítása az } \\
\text { üzleti oldallal való } \\
\text { egyetértésben }\end{array}$ & $\begin{array}{c}\text { folyamatmenedzsment (üzleti modellek, fo- } \\
\text { lyamatok, szerepkörök, szervezeti felépítés } \\
\text { tervezése) } \\
\text { adattervezés } \\
\text { rendszerintegráció } \\
\text { rendszertervezés (szolgáltatás-, megoldás- } \\
\text { tervezés, architektúra, alkalmazástervezés } \\
\text { valamint ezek építőelemeinek tervezése, } \\
\text { iparági standardok ismerete) } \\
\text { rendszerelemzés (monitorozás) } \\
\text { költség/haszonelemzés }\end{array}$ & Tudás \\
\hline $\begin{array}{l}\text { Program-, és pro- } \\
\text { jektmenedzseri } \\
\text { feladatok }\end{array}$ & $\begin{array}{l}\text { program-, projektmenedzsmenthez, változás- } \\
\text { kezeléshez, valamint értékeléshez kapcsolódó } \\
\text { eszközök ismerete }\end{array}$ & Tudás \\
\hline
\end{tabular}




\begin{tabular}{|c|c|c|}
\hline IT & $\begin{array}{c}\text { rendszerfejlesztés( } \\
\text { alkalmazásfejlesztési metodológiák és esz- } \\
\text { közök } \\
\text { programozási nyelv } \\
\text { közvetítő alkalmazások (brokering } \\
\text { applications) } \\
\text { Web-alapú szolgáltatások } \\
\text { Information Consumer and Provider al- } \\
\text { kalmazások }{ }^{23}, \text { felhasználói felületek) } \\
\text { eszközgazdálkodás (asset management), } \\
\text { üzemeltetés (SLA-k, infrastruktúra) } \\
\text { szervízprogramok (utilityk) kezelése, rend- } \\
\text { szerismeretek ) } \\
\text { migráció tervezés } \\
\text { Enterprise Continuums } \\
\text { kulcsrakész szoftverek } \\
\text { szoftverfejlesztés } \\
\text { biztonság } \\
\text { hálózatkezelés } \\
\text { tranzakció-feldolgozás, } \\
\text { International Operations } \\
\text { adathozzáférés, adatkezelés, adatcsere } \\
\text { operációs rendszer, hálózati szolgáltatások } \\
\text { kommunikációs infrastruktúra kialakítása }\end{array}$ & Tudás \\
\hline Jogi környezet & $\begin{array}{l}\text { adatvédelmi törvény, csalás elleni küzdelem } \\
\text { jogi alapjai }\end{array}$ & Tudás \\
\hline
\end{tabular}

12. táblázat $\mathrm{A}$ vállalati architekt alkalmazási tárgyterülethez kapcsolódó kompetenciái

A szoftverfejlesztői munkakörhöz kapcsolódó ismeretek az alábbi tudásterülethierarchiába rendezve kerültek be a meta-modellbe. A föbb csoportokat az összeha-

\footnotetext{
${ }^{23}$ Az alkalmazások információt szállító, vagy felhasználói szerepkör szerinti csoportosítása.

${ }^{24}$ Egy olyan szemléletmód elsajátítása, amivel az erőforrások, humán kompetenciák, módszerek, eszközök kiegyensúlyozott alkalmazásával az igényeknek, követelményeknek megfelelő folyamatos üzletvitel biztosítható.

${ }^{25} \mathrm{Az}$ országonként eltérö törvényeknek pl. adatvédelmi törvényeknek megfelelően történő működtetés.
} 
sonlítást előkészítendően a Képzési Kimeneti Követelmény Ontológiában szereplő tudásterületek adják.

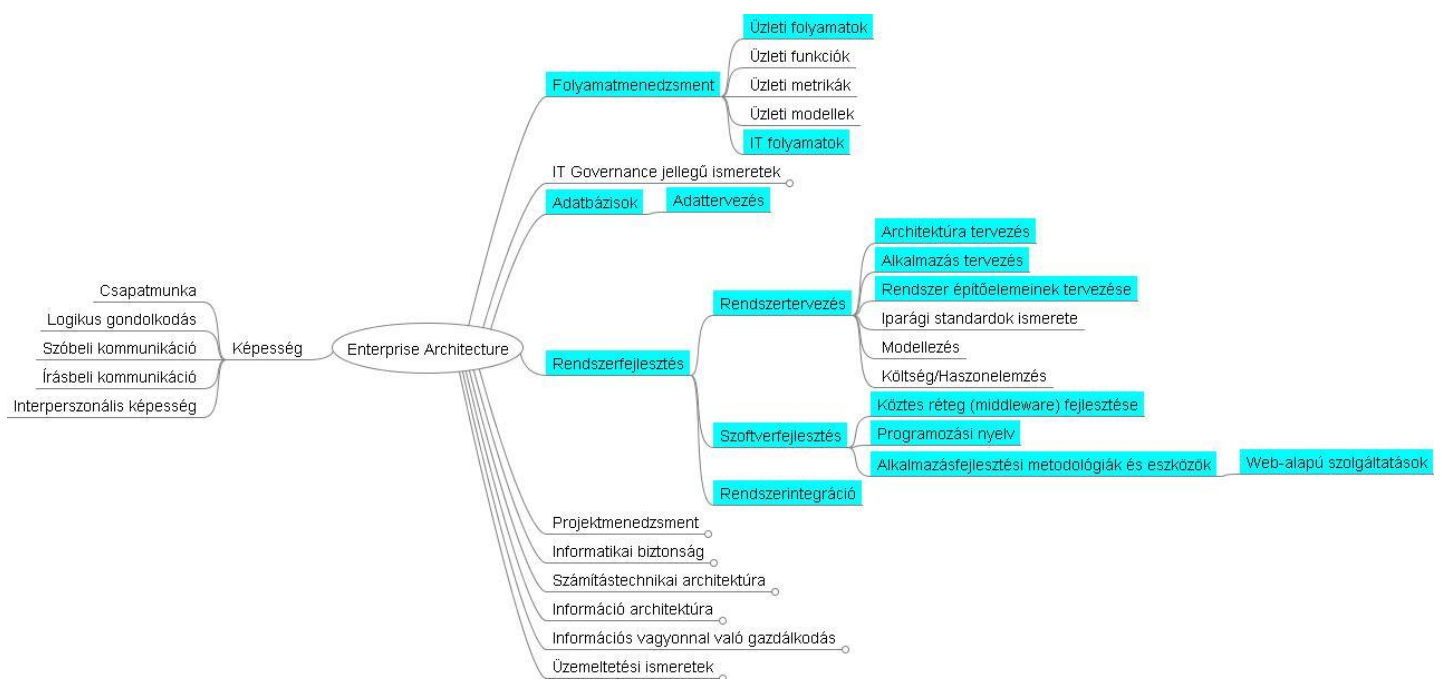

20. ábra Vállalati architektúráért felelős személytől elvárt ismeretek

Mivel a kompetencia inkább csak a képesség, tudás, attitűd hármas gyűjtő fogalma, ezért a felvitt tudáselemek közvetlenül a feladatokkal kerültek összerendelésre. Itt jegyezném meg, hogy rendszerben még nincs kezelve az egyes kompetenciák egymásra épülése (pl. az Architektúra tervezés igényli a Számítástechnikai architektúra ismeretét). Azonban a megfelelö relációval (előfeltétel) szabadon bővíthető. Az így létrejött Munkaköri Leírás Ontológia végső változatát mutatja be a 20. ábra. (Mivel az összes osztály megjelenítése kautikus lett volna, ezért a Szoftverfejleszés tudásterülethez tartozó feladatok köré lett az ábra csoportosítva.) 


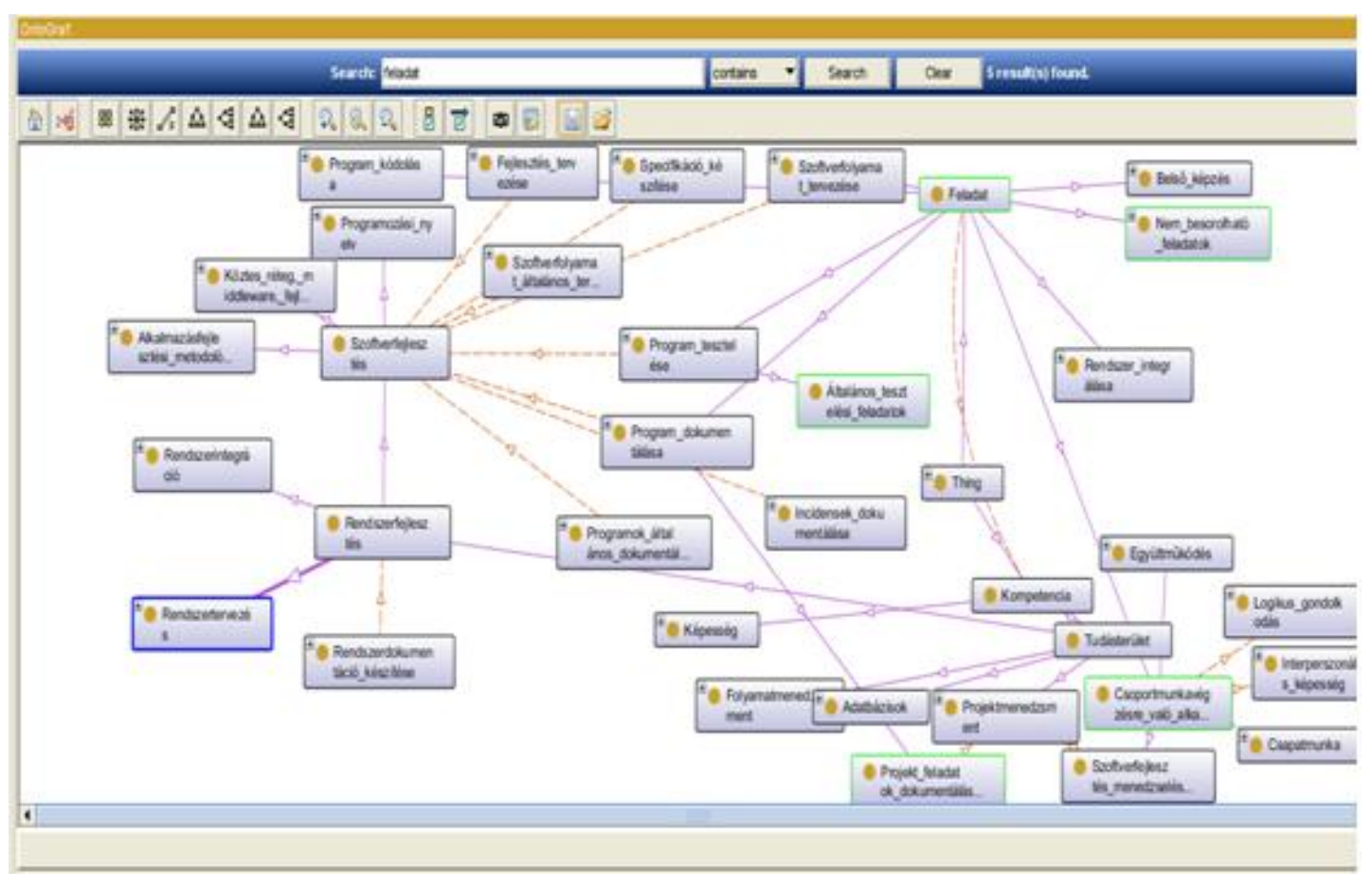

21. ábra MLO kompetenciákkal bővített vázlatos hierarchiája

\section{IV.1.5.3. KKKO és MLO példányosítása}

Ezek után került sor a két ontológia példányosítására. Az MLO példányainak alapjául a 2012. októberében a Profession.hu IT Fejlesztés/Programozás kategóriájában meghirdetett 679 állásajánlat szolgált. Az előző szürések végrehajtása után - azaz legyen benne Feladatok: és hirdetések blokk - már csak 164 állásajánlat került feldolgozásra. Az letöltéskor készített excel tábla tartalma (link, munkakör neve, régió, dátum stb.) az előbb említett program segítségével ki lett bővítve a hozzá kapcsolódó feladatokkal, valamint a maximum 1-2 év tapasztalatnak megfelelö BSc szintet mutató jellemzővel. Mindezek alapján 24 darab BSc szintü állásajánlat kerülhetett feldolgozásra.

A következő lépésben az egyes Feladat alosztályokhoz olyan tag-ek lettek rendelve, amelyek a legjellemzőbb egy, vagy két szavas szókapcsolatokat mutatják pl. a nyitott kérdéseknél kapott kifejezéseket. Az algoritmus 70 feladatot talált, amiből 6-ot két osztályhoz is sorolt, ugyanis a hirdetők egyszerre több feladatot soroltak fel bennük. Azaz a 146 BSc feladat 49,8\%-át dolgozta fel, amelyekhez kapcsolódóan 11 kompetenciát, ebből 7 tudásterületet példányosított. Az alábbi táblázat mutatja a feladatok megoszlását: 


\begin{tabular}{|c|c|c|c|c|}
\hline Feladat & $\mid \begin{array}{c}\text { Találatok } \\
\text { szám }\end{array}$ & \begin{tabular}{|c|} 
Nem \\
releváns
\end{tabular} & Nem releváns találatok jellemzổi & Kapcsolódó kompetenciák \\
\hline Adatbázis tervezése & 3 & 3 & projektek tervezése & Adattervezés \\
\hline Alkalmazások tervezése & 3 & & & Alkalmazás tervezés \\
\hline Belsố képzés & 6 & 3 & felhasználók oktatása & Tudásmegosztás képesége \\
\hline Csoportmunkavégzésre való alkalmassági feladatok & 3 & 0 & & Csapatmunka \\
\hline Csoportmunkavégzésre való alkalmassági feladatok & & & & Interperszonális képesség \\
\hline Csoportmunkavégzésre való alkalmassági feladatok & & & & Logikus gondolkodás \\
\hline Fejlesztés tervezése & 1 & 1 & tervezés, fejlesztés & Szoftverfejlesztés \\
\hline Program kódolása & 1 & & & Programozási nyelv \\
\hline Program tesztelése & 23 & 5 & tesztelések koordinálása, tervezése & Szoftverfejlesztés \\
\hline Programok általános dokumentálása & 12 & & $\begin{array}{l}1 \text { projekt, } 1 \text { folyamat feladat } \\
\text { dokumentálása }\end{array}$ & Szoftverfejlesztés \\
\hline Projekt irányítása & 13 & 3 & simán részvétel & Projektmenedzsment \\
\hline Rendszer tervezése & 4 & 1 & SOA felügyelet & Rendszertervezés \\
\hline Rendszerdokumentáció készítése & 1 & & & Rendszerfejlesztés \\
\hline Specifikáció készítése & 5 & 1 & specifikáció alapján történố fejlesztés & Szoftverfejlesztés \\
\hline Szoftverfolyamat általános tervezése & 1 & & & Szoftverfejlesztés \\
\hline Összesen & 76 & 19 & & 11 \\
\hline
\end{tabular}

13. táblázat Találatok megoszlása

Ahogy a táblázatból kiderül 75\%-ban releváns találatok születtek, azonban az ontológiát egy kicsit át kellett alakítani. Ugyanis az Adatbázis tervezése, illetve a Fejlesztés tervezése feladatnál egyáltalán nem született releváns találat, viszont a Programok_általános_dokumentálásába került beosztásra egy Projekt dokumentálása és egy Folyamatok dokumentálása feladat. Azaz az Adattervezés tudásterület példánya törlésre, a Folyamatemenedzsment tudásterület példány felvételre került, ami a kompetenciák számát nem változtatta meg.

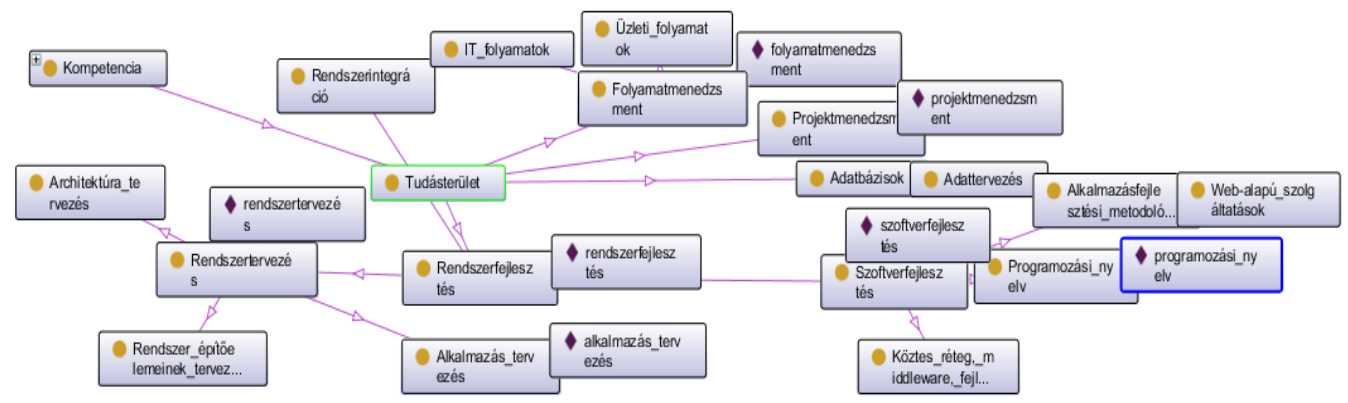

22. ábra Példányosított tudásterületek

A KKKO ontológiában minden tudásterület osztály példányosítva lett (12. ábra), ugyanis az aktuális kompetencia-elemek kerültek be a rendszerbe. Az attribútumok 2012. évre, BSc szintre és Budapest régióra lettek beállítva, ugyanis ez budapesti 
képzés, illetve a 2009., és 2012. októberében megvizsgált állásajánlatok 74\%-a is budapesti munkavégzéssel lett meghirdetve. ${ }^{26}$

\section{IV.1.6. Az első fejlesztési szakasz értékelése}

Összességében tehát egy olyan szoftverfejlesztési folyamatszakasz került megvalósításra, amely során a meta-modellek Protégé 4.1-ben történő felvitele után egy Java crawler, szövegfeldolgozó scriptek, valamint Java OWL API a letöltött állásajánlatokból apró belenyúlásoktól eltekintve ${ }^{27}$ automatikusan képes volt a Munkaköri Leírás Ontológia meta-modelljének kibővítésére. Azonban a nyelvi sokszínűségnek köszönhetően szükség volt a meta-modell revíziójára, valamint a tudáselemek TOGAF-ból történő kinyerésére. Ezzel párhuzamosan az Információrendszerek Tanszéken kidolgozott képzési elemek is beépültek a Képzési Kimeneti Követelmény Ontológia meta-modelljébe. A példányosításnak köszönhetően az egyes tudáselemek térbeli, időbeli, valamint szintbeli viszonyuk szerint kerültek be mind a két oldalon a rendszerbe. Vagyis létrejött a két oldal kompetencia-elemeit, elsősorban képességeit, tudáselemeit bemutató foglalkozási-, és szakmastruktúra az igényelt módokon strukturálva. Megállapítható, hogy a kidolgozott inkrementumok a 4. fejezet elején megfogalmazott követelményeknek megfeleltek, azaz sor kerülhetett a következő fejlesztési fázisra.

Az állásajánlatok pontosabb megszürésére törekedve, valamint újabb nyitott kérdések és tag-ek felvételét követően ezek a fázisok egymást, vagy a következő fázist követően többször is végrehajthatók, ezáltal folyamatosan finomítva, bővítve a modellt.

\section{IV.2. A fejlesztés második fázisa: az ontológiák egymáshoz illesztése}

Ebben a fázisban a két ontológia illeszkedésének a vizsgálata a hiány-, illetve többletkompetenciák feltárására irányult. Vagyis a szakasz célja egy olyan eszköz megtalálása, vagy fejlesztése volt, amely az előző szakaszban létrehozott ontológiákat öszsze tudja hasonlítani, valamint kezelni tudja a Protégé 4.1 által biztosított

\footnotetext{
${ }^{26}$ A munkaerőpiac ilyen szempontból történő elemzését tartalmazza a szerző A felsőokatási képzések munkaerőpiaci szempontból való vizsgálata c. cikke, ami a 2013-as év folyamán fog megjelennia Vezetéstudomány c. folyóiratban.

${ }^{27}$ Pl.: A karakterkonverzió miatt a Protégé szövegszerkesztő által nem kezelhető karakterek, valamint a speciális karaktereik pl. \# kitörlése.
} 
ontológialeíró nyelvek valamelyikét. Ezért ebben a szakaszban elöször ezen tárgyterület megfelelő elméleti hátterének, illetve gyakorlati tapasztalatainak a birtokában, az előző fázissal összeépíthető és egy elfogadható találati arányt biztosító eszköz, vagy algoritmus kiválasztását, vagy ennek hiányában új eszköz fejlesztési lehetőségét vizsgáltam meg.

\section{IV.2.1. Ontológiák egymáshoz illesztése, kezelése}

Klein (2001) két kategóriába sorolta az eltérő nézőpontból, tudásaspektusból származó ontológiák közötti különbségeket. A nyelvi, vagy meta-modell szinten való eltérés jelenti az osztályok, kapcsolatok stb. definíciós mechanizmusa közötti különbséget. A nyelvek különbözhetnek szintaktikájukban, kifejezőképességükben, ugyanazon nyelvi primitívek szemantikájában vagy egyazon logikai elemek eltérő, de egymással ekvivalens deklarációjában is. A normalizációs eljárás során lefordítják az ontológiákat ugyanarra a nyelvre, ezzel megoldva a problémát. Amennyiben ugyanaz a reprezentációs nyelv, felléphet ontológia-szintü különbség is, ami eredhet az eltérő fogalomalkotásból (pl. a tárgykör mely részét modellezik le), modellezési stílus választásától, terminológiai különbségekből (szinonimák, homonimák használatából), illetve más formátumú értékadástól.

Az ontológiák egymással történő összekombinálása megvalósulhat egyesítés, transzformálás, integráció, összerendelés, verziózás, leképezés, átfordítás stb. formájában. Az egyes kutatási ágak attól függően különböznek, hogy mely tevékenységekre helyezik a hangsúlyt. Az ontológiamenedzsment foglalkozik az ontológiák megváltozásából származó eltérések kezelésével, verziózásával, valamint egymáshoz illesztésével, sorbarendezésével egy közös tároló rendszer létrehozása végett. A változások három nagy területen - témakör, fogalomalkotás, specifikáció terén - következhetnek be. Egy jó változáskezelést elősegítő metodológiának részben automatikus adat-, és ontológia transzformációt kell végrehajtania, mindamellett, hogy lehetővé teszi a témakör, vagy fogalomalkotás területén bekövetkező változások miatt kialakult inkompatibilitás feloldását, a változások precíz leírását és a fogalmakra vonatkozó következmények meghatározását. A tárolórendszer kialakítása során speciális ontológiák segítik az ontológiák összehasonlítását, osztályokba sorolását és eltárolását. Követelmény velük szemben az ontológiák kapcsolatainak vizuális megjelenítése, a moduláris szerveződés, konzisztencia-ellenőrzés, valamint megfelelően végzett dokumen- 
tálás, azaz információk rendelkezésre bocsátása az ontológiák felépítéséről, a kiterjesztéséről, kibővítési lehetőségeiről, az elnevezési előírásáról, a szerveződési elvekről és függvényekről stb. Interaktívabb visszakeresést valósít meg egy ontológiákra épülő következtetőmotor beépítése, vagy heurisztikus visszakeresési eljárások alkalmazása is (Fensel et al., 2002).

Az ontológia mediáció az ontológiák, illetve ezek annotációs adatainak a különböző heterogén alkalmazások általi újra felhasználását támogatja az ontológiák közötti eltérések meghatározásával, valamint feloldásával. Amennyiben az ontológiák közötti kapcsolatokat azoktól elszeparáltan tároljuk, és csak a lekérdezések során használjuk fel, beszélhetünk ontológiák leképezéséről (ontology mapping), amikor viszont egy közös ontológiába helyezzük el őket ontológia egyesítés (ontology merging) következik be. A kapcsolatok fél-automatikus feltérképezése az ontológiaösszerendelés (ontology alignment) során hajtódik végre (Bruijn et al., 2006). A szakirodalomban az ontológiák leképezése az elöbb említett meghatározásnál sokkal szélesebb tudományterület. Kalfoglou és Schorlemmer (2003) értelmezésében az ontológiák összerendelésénél, tagolásánál és egyesítésénél sokkal több lehetőséget magában rejtő tevékenység egy részét képezi. Choi et al. (2006) is úgy tekint erre a területre, mint amelyik nélkülözhetetlen ezekben a folyamatokban.

Mivel a szakma-, és a foglalkozási struktúrát reprezentáló ontológiák közötti kapcsolat feltérképezése, és nem a két ontológia egyesítése a célom, ezért a továbbiakban az ontológiák leképezésével, illetve összerendelésével fogok foglalkozni.

\section{IV.2.1.1. Ontológiák leképezése}

Su (2002) meghatározásában, ha adott A és B ontológia, akkor az A B-vel vett leképezése azt jelenti, hogy minden egyes A-beli fogalomnak keressük a kölcsönösen megfelelő - megegyező, vagy hasonló szemantikával rendelkező - B-beli fogalompárját. Azaz szükségünk van két fogalom közötti szemantikus kapcsolat definiálására, és egy algoritmus kifejlesztésére, amely megtalálja a hasonló szemantikai jelentésü fogalmakat. A leképezési folyamat eredménye leképezési szabályok halmaza, amelyek megadják, hogy mely A-beli fogalomhoz mely B-beli fogalmat rendeljük.

Erre az elméletre építve dolgozta ki Ehrig és Sure (2004) a map : $\mathrm{O}_{\mathrm{i} 1} \rightarrow \mathrm{O}_{\mathrm{i} 2}$ ontológia leképezés függvényt az alábbi módon: 
map $\left(e_{i 1} j_{1}\right)=e_{i 2} j_{2}$, ha $\operatorname{sim}\left(e_{i 1} j_{1}, e_{i 2} j_{2}\right)$ értéke nagyobb, mint a t küszöbérték, akkor $\mathrm{e}_{\mathrm{i} 1} \mathrm{j}_{1}$ leképezése $\mathrm{e}_{\mathrm{i} 2} \mathrm{j}_{2}$, azaz szemantikailag azonosak. Azonban minden $\mathrm{e}_{\mathrm{i} 1} \mathrm{j}_{1}$-nek legfeljebb egy $\mathrm{e}_{\mathrm{i} 2 \mathrm{j}_{2}}$ leképezési pontja lehet. Ahol

- az O ontológia $\mathrm{O}:=\left(\mathrm{C}, \mathrm{H}_{\mathrm{C}}, \mathrm{R}_{\mathrm{C}}, \mathrm{H}_{\mathrm{R}}, \mathrm{I}, \mathrm{R}_{\mathrm{I}}, \mathrm{A}\right)$ egy rendezett hetes. A séma $\mathrm{C}$ fogalmai a $\mathrm{H}_{\mathrm{C}}$ alárendelési hierarchiába vannak rendezve. Az egyes fogalmak között $\mathrm{R}_{\mathrm{C}}$ reláció létezik, amelyek a $H_{R}$ hierarchiába vannak rendezve. A fogalmak I egyedei az $R_{I}$ tulajdonság-egyeddel vannak összekapcsolva. Az A axiómák segítségével lehet következtetéseket levonni a már meglévő tudáshalmazból. $\mathrm{O}_{\mathrm{i}}$ az i.-dik ontológia, ahol i $\in \mathrm{N}$.

- $\operatorname{sim}(\mathrm{x}, \mathrm{y})$ : hasonlósági függvény, amelynek az értékkészlete a [0;1], valamint reflexív, szimmetrikus, teljesül rá a háromszög-egyenlőtlenség. A távolság-függvény inverze. 1 esetében a két objektum teljesen azonos, 0 esetében teljesen különböző.

- $\mathrm{e}_{\mathrm{ij}}: \mathrm{O}_{\mathrm{i}}$ entitásai, azaz $\mathrm{e}_{\mathrm{ij}} \in\left\{\mathrm{C}_{\mathrm{i}}, \mathrm{R}_{\mathrm{i}}, \mathrm{I}_{\mathrm{i}}\right\}, \mathrm{j} \in \mathrm{N}$.

- $\operatorname{sim}\left(e_{i 1} j_{1}, e_{i 2} j_{2}\right): A z e_{i 1} j_{1}$ és $e_{i 2} j_{2}$ entitások közötti hasonlósági függvényérték, ahol $\mathrm{i}_{1} \neq \mathrm{i}_{2}$.

Azonban amíg Su, illetve Ehrig és Sure halmazelméleti alapokból indul ki, addig Kalfoglou és Schorlemmer inkább logikai elméletekre épít. Az ontológiát az $\mathrm{O}=$ (S,A) párként értelmezik, ahol S a szójegyzéket leíró (ontológiai) szignatúra, míg A az (ontológiai) axiómák egy halmaza, amely specifikálja az adott tárgyterület szójegyzékének egy szándékolt interpretációját. Az ontológiai szignatúra matematikai struktúrákkal leírható. Például a fogalmi, vagy az osztály szimbólum hierarchia, illetve a fogalmakon, mint argumentumokon definiált reláció-szimbólumok részben rendezett halmazt alkotnak. Az ontológiai axiómák halmaza az ontológia típusától függően le van korlátozva az axiómák egy bizonyos osztályára. A morfizmusra, azaz a matematikai struktúrák közötti struktúra-megőrző leképezésre (pl. a részben rendezett halmazok morfizmusára) építve definiálják az ontológiai leképezést. Azaz teljes ontológiai leképezésről beszélünk, ha $\mathrm{O}_{1}=\left(\mathrm{S}_{1}, \mathrm{~A}_{1}\right)$ és $\mathrm{O}_{2}=\left(\mathrm{S}_{2}, \mathrm{~A}_{2}\right)$ között létezik egy olyan f: $\mathrm{S}_{1} \rightarrow \mathrm{S}_{2}$ ontológiai szignatúráknak egy olyan morfizmusa, amely az $\mathrm{O}_{2}$ axiómát kielégítő összes interpretációjában kielégíti az $\mathrm{O}_{1}$ leképezett axiómáját is, azaz $\mathrm{A}_{2} \mid=\mathrm{f}\left(\mathrm{A}_{1}\right)$. Egy megengedőbb definíció szerint $\mathrm{O}_{1}=\left(\mathrm{S}_{1}, \mathrm{~A}_{1}\right)$-böl $\mathrm{O}_{2}=\left(\mathrm{S}_{2}, \mathrm{~A}_{2}\right)$-be történő parciális ontológiai leképezésről beszélünk, amennyiben létezik egy olyan $\mathrm{O}^{\prime}{ }_{1}=$ $\left(\mathrm{S}_{1}{ }_{1}, \mathrm{~A}^{\prime}{ }_{1}\right)$ rész-ontológia (ahol, $\left.\mathrm{S}_{1} \subseteq \mathrm{S}_{1}, \mathrm{~A}^{\prime}{ }_{1} \subseteq \mathrm{A} 1\right)$, amelyhez már található teljes $\mathrm{O}_{2}$-re 
való leképezés. Ehrig-Sure és Kalfoglou-Schorlemmer eltérő megközelítést használt annak alapján, hogy az egyes ontológiák ábrázolására milyen matematikai elméletet alkalmaztak. Ettől függően használtak fel matematikai eszközöket - azaz a hasonlósági függvényt, vagy az ontológiai szignatúrák morfizmusát - a két ontológia entitásai közötti kapcsolat leírására. A leképezés kifejlesztését segítik elő a metodológiai hátteret biztosító keretrendszerek, módszerek, eszközök, technikák, vagy a gyakorlati tapasztalatokat közvetítő jelentések, összehasonlító-, illetve esettanulmányok. A szakirodalomban Kalfoglou és Schorlemmer (2003) mutatja be a legátfogóbban ezen területeket, azonban mindemellett felelhetőek szükebb területen történő vizsgálódások is (pl. Ding és Foo, 2002a, 2002b; Noy, 2004; Ehrig és Sure, 2004; Choi et al., 2006). Mivel ez a tudományterület nagyon széles eszköztárral rendelkezik, ezért a további vizsgálatok céljából azokat kívántam csak figyelembe venni, amelyek a dinamikus (a munkaadói kompetenciák időszakos változását megfelelően követő) környezetben történő összehasonlítást tesznek lehetővé, valamint amelyek elösegítik a hasonló fogalmak, illetve tulajdonságok megtalálását. Ezért az elöbb említett legszélesebbkörü tanulmány figyelembevétele mellett Choi et al. (2006) ajánlása alapján a dinamizmust kezelni tudó lokális ontológiák közötti leképezést segítő eszközöket (Context OWL, CTXMATCH, GLUE, MAFRA, LOM, QOM, ONION, OKMS, OMEN), valamint a Noy (2004) által bemutatott leképezés felfedezését támogató eszközöket (SUMO és DOLCE formális, magas szintű ontológiák, ISI/USC, PROMPT, FCA-MERGE, IF-MAP) vizsgáltam meg. Ezért a C-OWL, CTXMATCH algoritmus, magas szintű ontológiák, FCA-MERGE ontológia egyesítő rendszer, ISI/USC gépi fordító rendszer, valamint az OKMS tudásmenedzsment rendszer bemutatására nem kerül sor. A Protégé OWL szerkesztőkben már nem a PROMPT plugin foglalkozik az ontológiák illesztésével, hanem az OWL Diff plugin, valamint a Compare Ontologies funkció. Ezért a PROMPT helyett ezeket elemeztem.

\section{IV.2.1.2. Ontológiaillesztést elösegítö módszerek és eszközök}

GLUE: egy olyan rendszer, amely ontológiák között gépi tanulási technikákra építve hoz létre fél-automatikus szemantikus leképezéseket. A két taxonómia közötti 1-1 típusú fogalom megfeleltetéseket keresi. A fogalmakat egyedek halmazának tekinti, amire építve multi-stratégiás tanulási algoritmus számolja ki a $P A ; B, P(\bar{A} ; B), P(A ; \bar{B})$ és $P(\bar{A} ; \bar{B})$ valószínüségekből álló, együttes valószínüségi 
eloszlásfüggvényt. (Ahol $P(A ; \bar{B})$ annak a valószínüségét adja meg, hogy az adott tárgyterület egyede az A fogalomhoz tartozik, de a B-hez nem.) Ezt a feladatot végzi el a Distribution Estimator. Ezekre a számokra építve a Similarity Estimator Jaccard koefficienst használva kikalkulálja a hasonlósági mértékeket. Majd a Relaxation Labeler tárgyterületi megszorítások, és általános heurisztikák alapján javítja a találat pontosságát és megadja a végső találati párokat (Doan et al., 2004).

MAFRA: az Interneten fellelhető ontológiák időben megváltozhatnak, ezért a kezelésük a kapcsolódó entitásokról készült statikus specifikáció helyett folyamatos, inkrementális, interaktív és dinamikus leképezési folyamatot igényel. A KAON alá fejlesztett keretrendszer kilenc komponensből áll:

- a leképezési folyamatot támogató öt horizontális modulból:

○ Lift\&Normalization: a közös reprezentációs nyelvre, azaz RDF(S) formára hozó modul.

○ Similarity: a hasonlósági mértékek kiszámításáért felelős modul.

○ Semantic Bridging: az entitások közötti kapcsolatot létesítő szemantikus híd modul. Négy, entitások - fogalmak, attribútumok, kapcsolatok, egyedek tartalmának modellezésére irányuló mintázatok - közötti kapcsolatokat reprezentáló híd létezik, amelyek az SBO (semantic bridging ontology) ontológiában vannak specifikálva. A forrás- és cél ontológia közötti kapcsolat létrehozásakor az SBO ontológia egy egyede képződik, amely a transzformációhoz szükséges összes információt tartalmazza.

○ Execution: ezen információk alapján az egyik ontológiából a másikba való transzformációt végrehajtó modul.

○ Post-processing: a transzformációt ellenőrző, minőségét javító modulból áll.

- a modulokkal interaktív kapcsolatot tartó, a háttérben müködő négy vertikális komponens:

- Evolution: a szemantikus híd fenntartásáért, illetve annak az ontológiákban bekövetkező változásokkal szinkronba hozásért felelős modul. 
○ Cooperative Consensus Building: a szemantikus hidat érintő kérdésekben a leképezési folyamatban résztvevő két fél konszenzusos megegyezését támogatja.

- Domain Constraints and Background Knowledge: a hasonlósági, valamint a szemantikus híd modul müködési minőségét drámaian javító háttértudás-anyag, valamint értelmezési tartomány korlátozások.

○ Graphical User Interface: az emberi beavatkozást megteremtő grafikus felhasználói felület.

Az ontológiák leképezése a szemantikus híd segítségével történik, amelynek az elkészítését segíti elő a többi komponens (Maedche, 2002).

LOM: fél-automatikus (a végén emberi validációt igénylö) lexikon-alapú ontológia leképező eszköz. Azon ontológiákra épít, amelyek logikai elméletekként épülnek fel, szójegyzékből és axiómákból állnak. Morfizmust kíván találni az adott ontológiák szójegyzéket alkotó fogalmai között. A szójegyzék osztályokba, egyedekbe, predikátumokba van formalizálva, amelyek közül az azonos típusúakat hasonlítja össze. A jegyzéket - akár többszavas - termlistába alakítja át.

- teljes term illesztés: kisbetűs alakjukat pontos szövegillesztéssel veti össze, amelynek az eredménye 1 , ha megegyeznek, 0 , ha nem.

- alkotószavak illesztése: szavakká bontják a termeket, amelyek közül a túl gyakoriakat kitörlik, majd a maradékot angol nyelven alapuló - más nyelvre is átformálható morfológiai eljárások alapján feldolgozzák és azokat pontos szövegillesztéssel hasonlítják össze a célontológiából származó termekkel. Az összeillesztett párok egy 0 és 1 közé eső numerikus értéket kapnak annak megfelelően, hogy mekkora hányadát képviselik az összeillő szavak az összes alkotószót tartalmazó halmaznak.

- synset $^{28}$ illesztés: minden term minden egyes szava, amennyiben előfordul a Wordnetben, valamilyen synset csoporthoz tartozik, amelynek van egy indexszáma is. Az alkotószavak index-számait hozzárendeli a termekhez, így azokat jeleníti meg, amelyeknek a legnagyobb számú közös synset száma van, majd az előző módszerhez hasonló értéket rendel hozzájuk.

\footnotetext{
${ }^{28}$ Wordnet kifejezés a szinonimák egy csoportja által kifejezett jelentésre, vagy értelemre vonatkozó-
} an. 
- típusillesztés: azokat a termeket, amik az előző metódusokkal nem adtak eredményt ebben a szakaszban típusvizsgálatnak vetik alá. Azaz a SUMO/MILO magas, illetve középszintủ ontológia közvetítésével kívánja megtalálni azokat a párokat, amelyeket ugyanahhoz a típushoz tartozó osztályok és tulajdonságok reprezentálnak. A legmagasabb pontértékűek eltárolódnak, és numerikus értéket nyernek az előző két metódusnál látott módon. A pontosságát nagymértékben befolyásolja az egyes szinteken szereplő ontológiai kategóriák száma.

A LOM a szemantikus alkalmazások számára szemantikus keresést és fordítást biztosító ASCS eszközkészlet fontos komponense (Li, 2004).

QOM (Quick Ontology Mapping): egy olyan fél-automatikus megközelítés, amely az illesztési módszerek hatékonysága, illetve nagyméretű ontológiák kezelésének hatásfoka közül elsősorban az utóbbin kíván javítani. RDF/S-re épülő ontológiákat kezel. Olyan hasonlósági függvényt definiál, amely különböző súlyokkal aggregálja a logikai kifejezésekre, szövegegyezőségre, szöveghasonlóságra, valamint két entitáshalmaz hasonlóságára vonatkozó előre definiált képlet alapján kiszámolt értékeket (Ehrig és Staab, 2004).

ONION (ONtology compositION System): automatizált illeszkedés generátorral rendelkező rendszer, amely a heurisztikus illesztők (matcher) alapján ajánl illesztéseket. Az ontológia egy $\mathrm{G}$ irányított, címkézett gráf, valamint $\mathrm{R}$ szabályok halmazának rendezett párja. A két ontológia minden termjén végigfutnak a matcherek, azonban az ajánlásokat a szakértő felülbírálhatja, majd a megváltoztatott, vagy kiegészített kapcsolatok a jövőbeli illesztések minőségének javítása érdekében tárolásra kerülnek. Az illesztők moduláris szerveződésűek, azaz alkalmazás-specifikus algoritmusokat lehet beleírni. Két típusuk van: nem iteratív pl. a fogalmak hasonlósági értékeit szó-hasonlósági táblázat alapján kiszámoló nyelvi illesztési eljárás,valamint az erre építő iteratív, pl. két egyező csúcs esetén a gyerekeket is összehasonlító struktúra-alapú heurisztikák (Mitra és Wiederhold, 2002).

OMEN (Ontology Mapping Enhancer): valószínűségi alapon müködő ontológia leképező eszköz. Az ontológia fö-, és alosztályokból, tulajdonságokat, vagy kapcsolatokat leíró attribútumokból áll, amelyek egy, vagy több értelmezési tartománnyal, illetve értékkészlettel rendelkeznek. Az osztályok között engedélyezett a többszörös öröklés. Erre épül fel a Bayes-háló gráf (BN graph), amelynek a csúcsai az ontológi- 
ák összeillesztett osztályai, vagy tulajdonságai, az élei, pedig az egyik BN csúcs másik BN csúcsra gyakorolt hatását reprezentálja. Annak a megadásához, hogy mely osztály-párok szerepeljenek a gráfban, illetve mely élek, kezdetben szükség van a gyökércsúcsok közötti valószínűségi-eloszlások kiszámolására, majd a bizonyos határérték felett elfogadott, a gráfba csúcsként felvett osztálypárosításból kiindulva ki kell számolni ezek valószínüségi eloszlásainak a hatását az egy adott távolságra lévő osztály-párosításra vonatkozóan. A különböző meta-szabályokat teljesítő értékeket a Feltételes Valószínűségi Táblázat tartalmazza. A határérték felett elfogadott új osztályokra kezdődhet elölről az eljárás. Azonban nemcsak osztálypárosítások egymáshoz való befolyásvizsgálatára alkalmas, hanem egyrészről azt is tudja kezelni, hogyha két, egy értékkészlettel rendelkező tulajdonság összeilleszthető, akkor nagy valószínüséggel az értelmezési tartományukat képező osztályok is azzá tehetők, vagy a főosztályok és azon testvérosztályainak illeszkedése alapján következtetést tud levonni a maradék testvérosztályok illeszkedésére vonatkozóan (Mitra et al., 2005).

OWL DIFF Protégé plugin fél-automatikus ontológia egyesítő és illesztő eszköz. A kezdeti összehasonlítás fázisában az axiómákra szintaktikai hasonlósági illesztést végez, amely alapján listát készít arról, hogy mely ontolóiga elemek vannak meg csak az egyik, illetve másik ontológiában. Logikai összehasonlításra, tartalmazások elemzésére is képes. Külön megadja osztályokra, egyedekre, illetve tulajdonságokra vonatkozóan az eltéréseket, illetve azt is meg lehet tekinteni, hogy az egyes oldalakon mely osztályok kiknek a részosztályai. (OWLDiff, 2008)

Compare Ontologies a Protégé 4.2 változatban beépített funkcióként szolgál. Tapasztalataim szerint eltérő névterü ontológiákat is képes összehasonlítani, ami az OWL Diff esetében nem megvalósítható. Képes mintázatok alapján is ajánlásokat tenni, amivel még pontosabb találatok születnek. Az eredményeket egy táblázatban ömlesztve mutatja be. Az összeillő párok az eltérő URI-nak köszönhetően a Renamed and Modified kategórián belül találhatók meg.

IF-MAP: Barwise-Seligman információfolyam elméletére épülő ontológia leképező módszer. A különböző forrásokból összegyüjti az esetlegesen eltérő formátumú ontológiákat, majd egy saját fordítóval áttranszformálja Prológ klózokba őket. Az ontológia leképezés folyamatában $\mathrm{f}^{*}$ ontológiai morfizmust keres a két ontológia között, 
ami maga után vonja egy logikai infomorfizmus ${ }^{29} \mathrm{f}=\left\langle\mathrm{f}^{*}, \mathrm{f}_{*}\right\rangle$ meglétét a két ontológiából transzformált logika között (ahol $\mathrm{f} *$ az infomorfizmus fogalmi-szintü megjelenése, azaz a fogalmak közötti leképezést adja meg). Az eredményeket a további felhasználás céljából eltárolja (Kalfoglou és Schorlemmer, 2002).

\section{Az eszközök értékelése}

A kutatásban való hasznosíthatóság érdekében az előbb említett eszközöknél azt vizsgáltam meg, hogy milyen dinamikusan tudják az összeilleszteni kívánt ontológiákban bekövetkező változásokat kezelni, illetve újrahasznosíthatóak-e egy esetleg későbbi fejlesztési folyamatban. A 10. táblázat a következő jellemzők alapján mutatja be az eszkök értékelését:

- dinamikus illeszkedésvizsgálatot elősegítő dimenziók:

○ automatizmus: mennyire automatikusan hajtja végre az illesztést manuálisan, fél-automatikusan, vagy automatikusan.

○ változáskezelés: milyen módon kezeli az ontológiákban bekövetkező változásokat.

- újrahasznosíthatóságot lehetővé tevő jellemzők:

○ ontológia modell: milyen ontológia-leíró nyelvekre épülő ontológia modelleket képes összehasonlítani, azaz a Protégé 4.1 formátumait fel tudja-e használni.

○ módszer: milyen metódus alapján hajtja végre az illeszkedésvizsgálatot.

○ modularitás: a más alkalmazásokkal való összeépíthetőséget támogatja-e szabad hozzáféréssel, nyílt forráskóddal, parancssorból való indíthatósággal.

\footnotetext{
${ }^{29}$ Bairwise és Seligman alapján az osztályok adják az alap mintázatokat az információáramlásban, amelyek két halmazt és a köztük lévő relációkat adják meg. Az infomorfizmus két ilyen osztály közötti kapcsolatot kíván létesíteni. Ezért meghatározza azokat a tényeket, amelyek az egyik halmazból információkat tudnak szállítani a másik halmaz tényeire vonatkozóan (Benthem-Israel, 1999).
} 
○ adaptálhatóság: alkalmazható-e a módszer magyar nyelvi környezetre is, azaz általános, vagy nyelv-specifikus pl. angol szótárra épülő algoritmust használ-e.

\begin{tabular}{|c|c|c|c|c|}
\hline & GLUE & MAFRA & LOM & QOM \\
\hline automatizmus & fél-automatikus & fél-automatikus & fél-automatikus & $\begin{array}{c}\text { fél- } \\
\text { automatikus }\end{array}$ \\
\hline változáskezelés & n.a. & $\begin{array}{l}\text { szemantikus } \\
\text { hídon keresztül } \\
\text { valósítja meg }\end{array}$ & n.a. & n.a. \\
\hline $\begin{array}{l}\text { ontológia mo- } \\
\text { dell }\end{array}$ & $\begin{array}{l}\text { fogalom- attri- } \\
\text { bútum-reláció } \\
\text { hármasba for- } \\
\text { malizáló nyel- } \\
\text { vekre épülö } \\
\text { modell } \\
\end{array}$ & $\begin{array}{l}\text { XML Schema, } \\
\text { RDF/S, illetve } \\
\text { KAON-ban } \\
\text { formalizált on- } \\
\text { tológia }\end{array}$ & $\begin{array}{l}\text { ASCS eszköz- } \\
\text { készlet által meg- } \\
\text { engedett nyelvek- } \\
\text { re épülő ontológia }\end{array}$ & $\begin{array}{l}\text { RDF/S onto- } \\
\text { lógia }\end{array}$ \\
\hline módszer & $\begin{array}{l}\text { gépi tanulási } \\
\text { technika } \\
\text { valószínüségi } \\
\text { eloszlások alap- } \\
\text { ján számított } \\
\text { hasonlósági } \\
\text { mérték } \\
\text { értelmezési tar- } \\
\text { tomány korláto- } \\
\text { zások, heurisz- } \\
\text { tikák }\end{array}$ & $\begin{array}{l}\text { hasonlósági } \\
\text { mértékekre épü- } \\
\text { lő szemantikus } \\
\text { híd, és az építé- } \\
\text { sét támogató } \\
\text { komponensek }\end{array}$ & $\begin{array}{c}\text { gépi tanulási } \\
\text { technika } \\
\text { szójegyzék közöt- } \\
\text { ti morfizmus ke- } \\
\text { resése } \\
\text { termek, alkotó- } \\
\text { szavak, synset, és } \\
\text { típus illesztése } \\
\text { által }\end{array}$ & $\begin{array}{l}\text { hasonlósági } \\
\text { függvényre } \\
\text { építve a le- } \\
\text { képezés ha- } \\
\text { tékonysága } \\
\text { és a hatásfo- } \\
\text { ka közül el- } \\
\text { sősorban az } \\
\text { utolsón kíván } \\
\text { javítani }\end{array}$ \\
\hline modularitás & $\begin{array}{c}\text { nem férhető } \\
\text { szabadon hozzá }\end{array}$ & $\begin{array}{l}\text { szabadon hoz- } \\
\text { záférhető, pa- } \\
\text { rancssorból in- } \\
\text { dítható }\end{array}$ & $\begin{array}{l}\text { nem férhető sza- } \\
\text { badon hozzá }\end{array}$ & $\begin{array}{c}\text { nem férhető } \\
\text { szabadon } \\
\text { hozzá }\end{array}$ \\
\hline adaptálhatóság & $\begin{array}{l}\text { általános algo- } \\
\text { ritmus }\end{array}$ & $\begin{array}{l}\text { általános algo- } \\
\text { ritmus }\end{array}$ & $\begin{array}{l}\text { angol nyelv- } \\
\text { specifikus, de át- } \\
\text { dolgozható }\end{array}$ & $\begin{array}{l}\text { általános } \\
\text { algoritmus }\end{array}$ \\
\hline
\end{tabular}




\begin{tabular}{|c|c|c|c|c|}
\hline & ONION & OMEN & $\begin{array}{l}\text { OWL DIFF/ } \\
\text { Compare } \\
\text { Otologies }\end{array}$ & IF-MAP \\
\hline automatizmus & fél-automatikus & fél-automatikus & fél-automatikus & automatikus \\
\hline változáskezelés & n.a. & n.a. & $\begin{array}{l}\text { Protégé-be ágya- } \\
\text { zottságán keresz- } \\
\text { tül kezeli }\end{array}$ & n.a. \\
\hline $\begin{array}{l}\text { ontológia mo- } \\
\text { dell }\end{array}$ & $\begin{array}{l}\text { IDL reprezentá- } \\
\text { cióra és XML- } \\
\text { alapú nyelvekre } \\
\text { épülő ontológia }\end{array}$ & $\begin{array}{l}\text { RDF(S) felépí- } \\
\text { téséhez hasonló } \\
\text { ontológia mo- } \\
\text { dell }\end{array}$ & $\begin{array}{l}\text { Protégé által ke- } \\
\text { zelt nyelvekre } \\
\text { épülő modellek }\end{array}$ & $\begin{array}{l}\text { KIF-ben, } \\
\text { Ontolingua- } \\
\text { tól kezdve } \\
\text { OCML nyel- } \\
\text { ven, RDF, } \\
\text { Prológ, } \\
\text { Protégé tu- } \\
\text { dásbázis } \\
\text { formátumban } \\
\text { megadott } \\
\text { ontológiák } \\
\end{array}$ \\
\hline módszer & $\begin{array}{l}\text { iteratív és nem } \\
\text { iteratív heurisz- } \\
\text { tikus illesztökön } \\
\text { alapul }\end{array}$ & $\begin{array}{c}\text { Bayes-hálón } \\
\text { alapuló meta- } \\
\text { szabályokra épít }\end{array}$ & $\begin{array}{l}\text { axiómák összeha- } \\
\text { sonlításán alapul/ } \\
\text { mintázatokat is } \\
\text { vizsgál }\end{array}$ & $\begin{array}{l}\text { ontológiai } \\
\text { morfizmust } \\
\text { keres }\end{array}$ \\
\hline modularitás & $\begin{array}{l}\text { szemantikus } \\
\text { következtetési } \\
\text { rendszerekbe } \\
\text { beépíthető, de } \\
\text { nem férhető } \\
\text { szabadon hozzá }\end{array}$ & $\begin{array}{c}\text { nem férhető } \\
\text { szabadon hozzá }\end{array}$ & $\begin{array}{l}\text { szabadon hozzá- } \\
\text { férhető, Java } \\
\text { programba be- } \\
\text { építhető }\end{array}$ & $\begin{array}{l}\text { nem férhető } \\
\text { szabadon } \\
\text { hozzá }\end{array}$ \\
\hline adaptálhatóság & $\begin{array}{l}\text { van angol- } \\
\text { nyelvspecifikus } \\
\text { hasonlósági } \\
\text { értékszámítása }\end{array}$ & $\begin{array}{l}\text { általános algo- } \\
\text { ritmus }\end{array}$ & $\begin{array}{c}\text { általános algorit- } \\
\text { mus }\end{array}$ & $\begin{array}{l}\text { általános } \\
\text { algoritmus }\end{array}$ \\
\hline
\end{tabular}

A legtöbb módszer - kivéve az IF-MAP-et - emberi beavatkozást igényel akár a folyamat végrehajtásában, akár az eredmények validálásában. A dinamikus illeszkedésvizsgálatra elsősorban a MAFRA képes, de programozással az OWL DIFF és a letölthető SVN Repository-val is rendelkező Compare Ontologies is azzá tehető. A rendszer fejlesztésében való használhatóságukat nagymértékben befolyásolja, hogy az ontológiaépítés folyamatát hogyan tudják folytatni. Ahogy a táblázatból kiderül a MAFRA esetében ez a parancssoros indítás beépíthetőségén, a másik két eszköz esetében pedig a Protégé-be való beágyazottságon múlik. Az RDF nyelvü ontológiát többen kezelik, azonban a Protégé-ben létrehozott fájlokat, csak az OWL 
Diff/Compare Ontologies és az IF-MAP tudja kezelni. Bár mind a MAFRA, mind az előbbi két program általános algoritmust használ, ezért a kutatásban való felhasználásuk attól függött, hogy milyen pontos találati arányt tudnak adni a szakmai, illetve foglalkozási oldalon előállított ontológiákra vonatkozóan, illetve a MAFRA be tudjae olvasni a Protégé-ből importált RDF fájlt.

\section{IV.2.2. A KKKO és MLO ontológiák összeillesztése}

A MAFRA Toolkit-ben egy összehasonlítási projekt indításához vagy XML Schema fájlra, vagy RDF(S) fájlra van szüksége. A Protégé 4.1 az OWL 2.0 fájlokat RDF fájlra tudja menteni, amelyet viszont a MAFRA nem tudott beolvasni. Ez nem is meglepő, hiszen a MAFRA Toolkit-et a szerzők 2009. májusában módosították utoljára, míg az OWL 2.0 megjelenése 2009. októberére tehető.

\section{IV.2.2.1. Összeillesztés végrehajtása Protégé 4.2-ben}

A Protégé 4.2 ontológiaszerkesztő az OWL Diff plugint, valamint a Compare Ontologies menüpontot kínálja ontológiák összehasonlítására. Az összeillesztés végrehajtása előtt az MLO ontológiában csak a Kompetencia tudásterület maradt meg, mivel a hasonlítás ennek az alosztályára a Tudásterületre fókuszál. Illetve az egyes fájlokban azonos IRI-ket kellett az ontológia-elemeknek megadni.

Az eredményeket a 23.-25.. ábra mutatja.

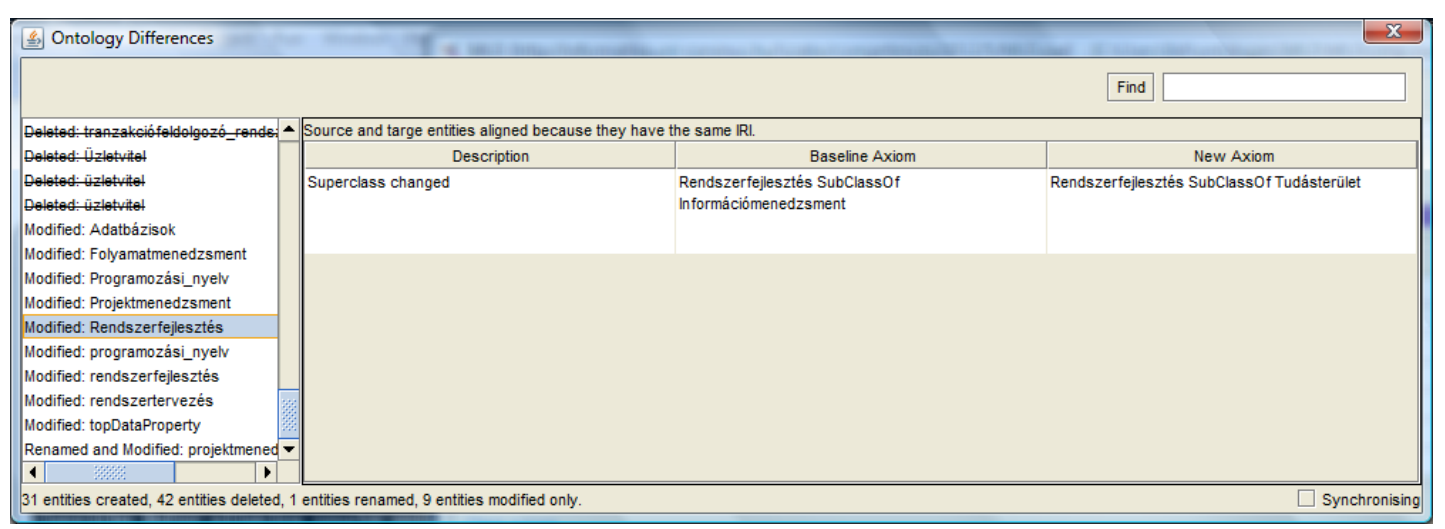

23. ábra Összehasonlítás eredménye Compare Ontologies menüpont segítségével 


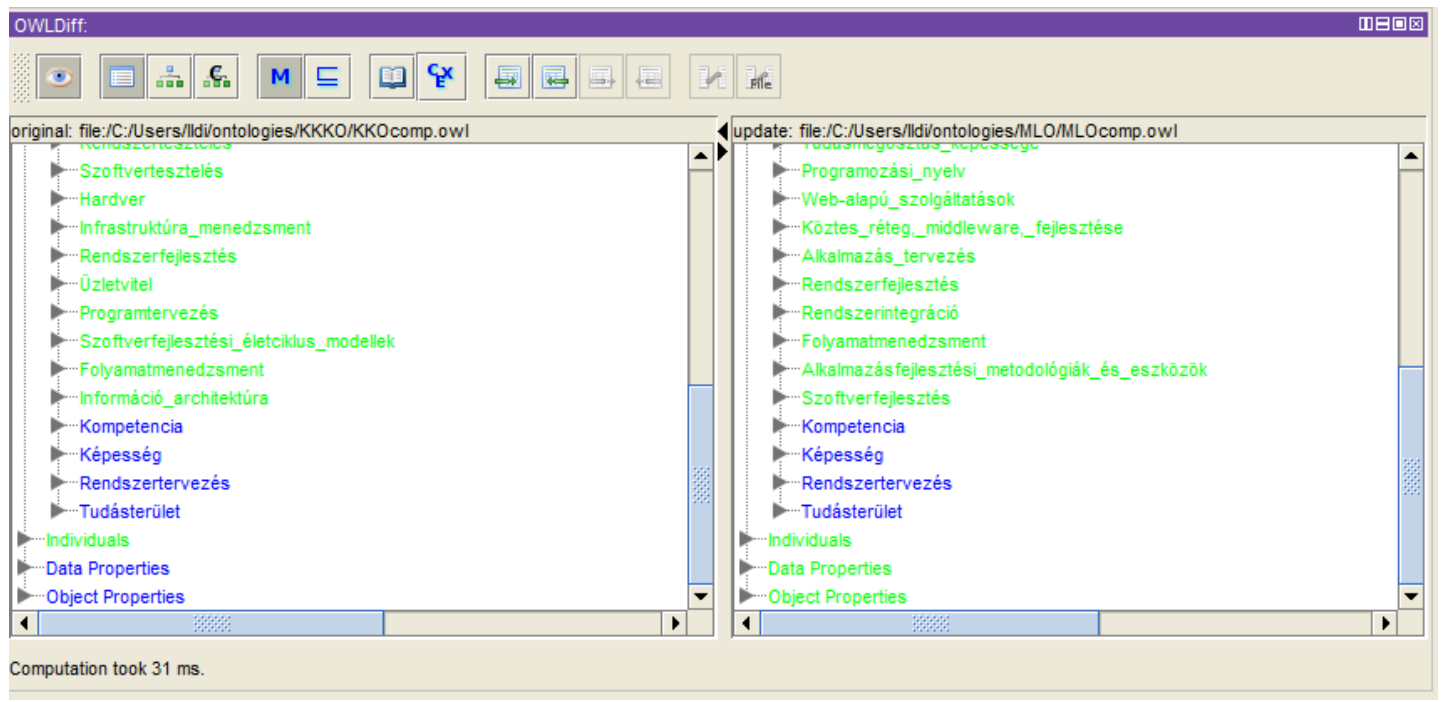

24. ábra Egyező és eltérő tudásterületek feltárása OWL Diff segítségével

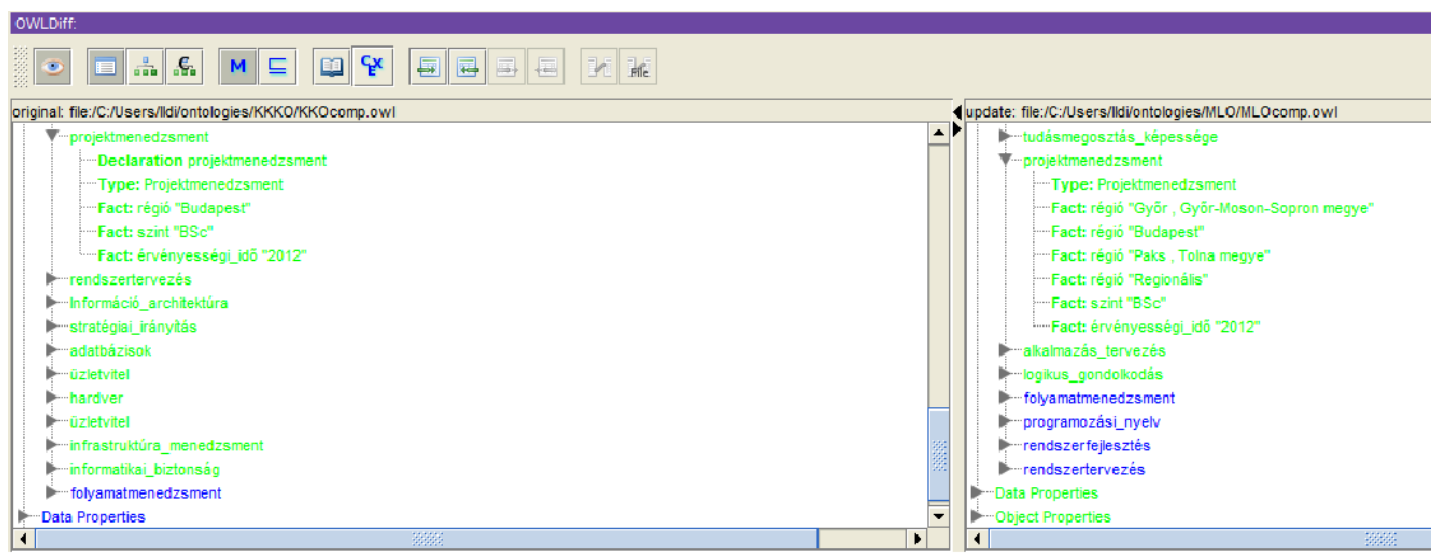

25. ábra Egyező és eltérő példányok feltárása OWL Diff segítségével

A Compare Ontologies eredményként megadja, hogy mely egyedek, osztályok lettek az egyik ontológiából (original) eltávolítva és létrehozva az új ontológiában (update). Az egyező elemeket pedig a Renamed and Modified kategória alá veszi. Az eredmény nehezen áttekinthető, hiszen nem csoportosítja külön, hogy melyek az osztályok, melyek az egyedek. Viszont ha rákattintunk egy eredményre, akkor külön ablakrészben részletezi, hogy milyen változást történt az adott elemmel.

Az OWL Diff eredménye sokkal jobban áttekinthető a külön csoportosításnak köszönhetően. Zölddel jelöli a különbségeket, kékkel az egyezőségeket. A projektmenedzsment példánynál láthatjuk, hogy bár a típus megegyezik, az eltérő régiók miatt nem találta egyezőnek a két példányt. A KKKO ontológiában nem jelöli a programozási nyelv, rendszerfejlesztés, illetve rendszertervezés példányok találatát, az MLO ontológiában viszont igen. Az alábbi ábrából kiderül, hogy ez azért van, mert az 
utóbbi három példányok eltérő deklarációk, azaz nem közvetlen, hanem Java API által történő felvitel által jöttek létre.

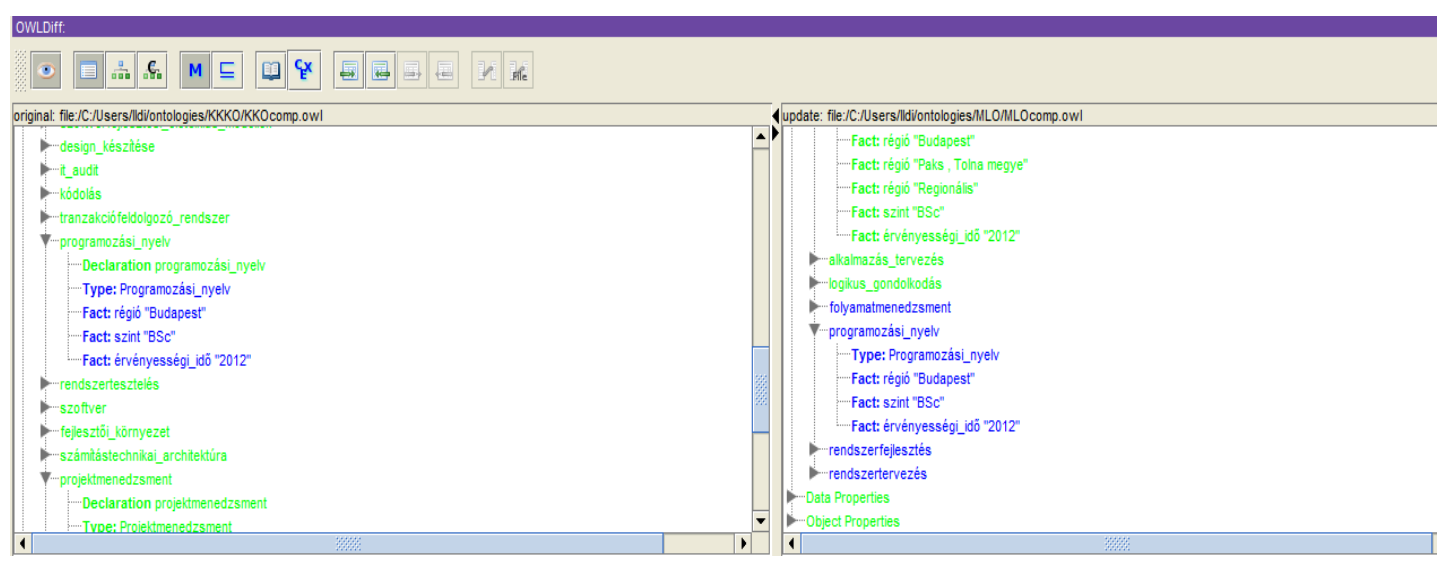

26. ábra Axiómabeli különbségek jelölése

Az alábbi táblázat tartalmazza a két oldal összehasonlítását tételes formában.

Összességében megállapíthatjuk, hogy a program egyező nevek esetén pontos találatot ad, figyelembe veszi az alosztályok és a deklarációs axiómákat, azonban a régiók halmazán belüli tartalmazást nem (1sd. 24. ábra). Azonban nyílt forráskódú és letölthető, ezért a jövőben továbbfejleszthető abban az irányban, hogy az egyes példányok/osztályok elnevezését szemantikailag is összehasonlítsa (pl. a LOM, vagy QOM esetében), illetve az adott attríbútumok egy adott halmazán belüli tartalmazást is kezelni tudja. 


\begin{tabular}{|c|c|c|c|c|}
\hline Képzési kompetenciák & $\begin{array}{l}\text { Kapcsolat } \\
\text { minôsítése }\end{array}$ & Munkaköri kompetenciák (2012. október) & \multicolumn{2}{|c|}{ X. szintũ kompetenciák } \\
\hline \multicolumn{3}{|c|}{ Képesség } & & \\
\hline & & $\begin{array}{l}\text { Csapatmunka, interperszonális képesség, } \\
\text { logikus gondolkodás, tudásmegosztás } \\
\text { képessége }\end{array}$ & & \\
\hline \multicolumn{3}{|c|}{ Tudásterület } & & \\
\hline \multicolumn{5}{|l|}{ Információ architektúra } \\
\hline \multicolumn{5}{|l|}{ Tranzakciófeldolgozó rendszer } \\
\hline Adatbázisok & $\begin{array}{l}\text { nem volt } \\
\text { igényelt }\end{array}$ & Adatbázisok & Adattervezés & \\
\hline \multicolumn{5}{|l|}{ Információmenedzsment } \\
\hline \multicolumn{5}{|l|}{ IT-audit } \\
\hline \multicolumn{5}{|l|}{ Informatikai biztonság } \\
\hline \multicolumn{5}{|l|}{ Infrastruktúra menedzsment } \\
\hline Projektmenedzsment & $\begin{array}{l}\text { több } \\
\text { régióban } \\
\text { felmerült }\end{array}$ & Projektmenedzsment & & \\
\hline Rendszerfejlesztés & talált & Rendszerfejlesztés & & \\
\hline \multirow[t]{4}{*}{ Rendszertervezés } & talált & \multirow[t]{4}{*}{ Rendszertervezés } & & \\
\hline & & & Alkalmazás tervezés & \\
\hline & & & Architektúra tervezés & \\
\hline & & & Rendszer épitỗelemeinek tervezése & \\
\hline \multicolumn{5}{|l|}{ Rendszertesztelés } \\
\hline \multirow[t]{3}{*}{ Szoftverfejlesztési életciklus modellek } & & \multirow[t]{6}{*}{ Szoftverfejlesztés } & & \\
\hline & & & \begin{tabular}{|l} 
Alkalmazásfejlesztési metodológiák \\
és eszközök
\end{tabular} & Web-alapú szolgáltatások \\
\hline & & & \begin{tabular}{|l|l} 
Köztes réteg middleware fejlesztése \\
\end{tabular} & \\
\hline \multicolumn{4}{|l|}{ Kódolás } & \\
\hline \multicolumn{4}{|l|}{ Fejlesztối környezet } & \\
\hline Programozási nyelv & talált & & Programozási nyelv & \\
\hline \multicolumn{5}{|l|}{ Programtervezés } \\
\hline \multicolumn{5}{|l|}{ Design_készítése } \\
\hline \multicolumn{5}{|l|}{ Specifikáció készitése } \\
\hline \multicolumn{5}{|l|}{\begin{tabular}{|l|} 
Szoftvertesztelés \\
\end{tabular}} \\
\hline \multirow{2}{*}{\multicolumn{5}{|c|}{\begin{tabular}{|l|} 
Számítástechnikai architektúra \\
Hardver
\end{tabular}}} \\
\hline & & & & \\
\hline \multicolumn{5}{|l|}{ Szoftver } \\
\hline \multicolumn{5}{|l|}{ Kommunikáció } \\
\hline \multicolumn{5}{|l|}{ Üzletvitel } \\
\hline \multicolumn{5}{|l|}{ Stratégiai irányitás } \\
\hline Folyamatmenedzsment & talált & Folyamatmenedzsment & IT folyamatok & \\
\hline & & & Üzletifolyamatok & \\
\hline
\end{tabular}

15. táblázat A két oldal egyezőségének és különbözőségének tételes feltárása

\section{IV.2.3. A második fejlesztési szakasz értékelése}

Ebben a szakaszban az előző fázisban előállított ontológiák összeillesztésére került sor. Neves szerzők müveiben szereplö illesztőeszközöket vizsgáltam, amelyeknek elsődleges céljuk az összehasonlítás és nem az egyesítés volt. Dinamikus illeszkedésvizsgálat, a modularitás és az elérhetőség tekintetében három szóbajöhető eszköz maradt, amelyből a MAFRA Toolkiten belüli vizsgálatra nem került sor annak köszönhetően, hogy nem tudta kezelni az OWL 2 nyelv RDF-ben lementett változatát. Itt jegyezném meg, hogy a nyelvi kifejezőerő csorbul ezzel a mentéssel, tehát még ha kezelni is tudta volna a fájlokat, előfordulhattak volna ebből fakadó hibák.

Maradt tehát a Protégé 4.2 ontológiaszerkesztő környezeten belül kínált OWL Diff és a Compare Ontologies menüpont használata. Mivel ez utóbbi nehezen áttekinthető eredményt adott, ezért a leginkább használhatónak az OWL Diff bizonyult. Ez az 
eszköz azonos nevek esetében pontos találatot adott, illetve csak deklarációbeli eltérésekre világított rá. A nyílt forráskódnak köszönhetően továbbfejleszthető, vagyis nemcsak az azonos nevek használata esetén lehet majd alkalmazni, illetve a régióbeli tartalmazást is képes lesz kezelni.

A 11 kompetencia-elem összehasonlítása még manuális úton is lehetséges lett volna, azonban a program mellett szól a rövid feldolgozási idő (31 másodperc) és a korlátai közötti (csak egyező nevek esetén) pontos találatok adása. Vagyis, ha figyelembe vesszük, hogy mind a szakmastruktúra, mind a foglalkozási struktúra mélységében tovább bővíthető, az időtényező mindenképpen a program használata mellett szól.

Megállapíthatjuk, hogy az OWL Diff egy olyan eszköz, amely az előző fázisban kialakított ontológiákat megfelelő formára hozás után képes összehasonlítani és az egyezőségüket, eltérőségüket tételesen feltárni.

Az első két hipotézis a rendszer fejlesztéséhez kapcsolódott, míg az utolsó a rendszer valós folyamatok közötti alkalmazhatóságát célozta meg, ami inkább oktatáspolitikai kérdést feszeget. 


\section{A rendszer integrálhatóságának vizsgálata}

A H.3 hipotézis foglalkozik azzal, hogy az előző pontokban bemutatott rendszer hasznos eleme-e a felsőoktatási döntés-elökészítési folyamatnak. Ez a hipotézis a jelen körülmények között nem tesztelhető, ugyanis a képzési kínálat átalakítása más elgondolások, nem kompetencia alapon történik. Ugyanis a Kormány a Széll Kálmán terv 2.0 verziójában megállapítja, hogy „kiemelt figyelmet fordít az állam által támogatott helyek számának és összetételének a gazdaság igényeinek függvényében történő megállapítására: az összlétszám szükitésével (pl. egyes szakokon a túlzott mértékü „diplomás munkanélküliség” csökkentése érdekében), valamint az intézményi keretek meghatározásával (megrendelöi szerepkörét érvényesítve)" (SZKTerv, 2012:199). Azaz a felsőoktatásból való forráskivonás miatt a képzési kínálatot a keretszámok megadásával, illetve államilag finanszírozott helyek számának csökkentésével szükíti be, és nem alapozza döntését a két oldal egyezőségének és különbözöségének kompetencia alapon történő vizsgálatára. A nemzeti felsőoktatásról szóló 2011. évi CCIV. törvény kimondja, hogy a „felsőoktatással kapcsolatos állami hatáskörök gyakorlásához, a nemzetgazdasági szintủ tervezéshez, továbbá a felsőoktatásban részt vevők jogainak gyakorlásához és kötelezettségeinek teljesítéséhez szükséges adatokat központi nyilvántartás tartalmazza (a továbbiakban: felsőoktatási információs rendszer)”, valamint a miniszter szabályozza a „a felsőoktatási szakképzés, az alapképzés és a mesterképzés képzési és kimeneti követelményeit" (FelsTv, 2012). Mint ahogy az 1. mellékletben láttuk, ezek túl széleskörüek ahhoz, hogyha be is kerülnek a felsőoktatási információs rendszer valamelyik moduljába, akkor sem alkalmasak a képzések munkaerőpiaci megfelelősségének vizsgálatára.

A jövőben viszont azzal, hogy útjára indul a két kapcsolódó projekt a SMART, illetve a Med-Assess, ezekhez csatlakozva lehetőségem nyílik az adott területeken alkalmazott döntéshozatali folyamatok rendszer általi támogathatóságának vizsgálatára. Ezek közül a SMART az, amelyik túlképzett, de magas munkanélküliségü spanyol régióra fókuszálva kívánja az eltéréseket kompetencia alapon magyarázni, azaz itt kerülnek elsősorban terítékre oktatáspolitikai kérdések. 


\section{A kutatás tapasztalatai}

A kutatás során kifejlesztett rendszer egy olyan megoldási lehetőségre világított rá, amely a felsőoktatás átstrukturálását érintő, jelenleg is aktuális közigazgatási döntéselőkészítési folyamatot más megközelítésből tudná támogatni, azaz a munkaerőpiac keresleti és kínálati oldalának képzettségre vonatkozó egyezőségeinek, illetve különbözőségeinek a feltárásával. A kompetenciára épülő modellek, valamint a képesítési keretrendszerek átláthatóbbá, tervezhetőbbé teszik mind a szervezeti tevékenységeket, mind a képzési programokat, ezért a kompetencia megfelelő alapot szolgáltat a munkaerőpiac két oldalán megjelenő szakma-, illetve foglalkozási struktúra összehasonlítására. Mivel a szakirodalomban a fogalomnak nincs egyezményes definíciója, attól függően kerül használatba, hogy milyen tevékenység (szerepkörhöz kapcsolódó feladat elvégzése, vagy tanulás) elvégzése érdekében kerül aktiválásra. Ezért a kutatásban, a mögöttes tartalmát legjobban reprezentáló tudás-képesség-attitüd hármasként lett interpretálva, amely valamilyen feladat elvégzéséhez kapcsolódik.

A rendszer ontológia alapú megközelítésben történő fejlesztését támasztja alá, az hogy az ontológia konzisztens alapot biztosít az összehasonlításra, valamint az egyes, ugyanerre a kutatási területre irányuló, továbbfejleszteni kívánt rendszerek is ebben a szemléletben készültek el.

A kutatás során egy prototípus került kidolgozásra, amely a BCE Gazdaságinformatikus képzésének, valamint a hozzá kapcsolódó IT munkakörök közül a Szoftverfejlesztő munkakör kompetenciatartalmait kívánta összehasonlítani. A választást magyarázza, hogy a 2009., illetve 2012. októberében, valamint 2010. augusztus és szeptember közepe letöltött állásajánlatok közel 90\%-ban megjelenő 13 szerepkör közül a fejlesztői szerepkör adta az összes megjelenő szerepkör egynegyedét. Azaz bár a Gazdaságinformatikus képzés elsősorban nem fejlesztőket képez, azonban kellően igényelt ahhoz, hogy az öt magában foglaló Szoftverfejlesztő munkakör a prototípus megfelelő alapját adja. Mindamellett, hogy ez a választás jelentős mennyiségü adatot is biztosított a számunkra.

A rendszer fejlesztése a kétfázisú inkrementális rendszerfejlesztési módszertan lépéseit követi, vagyis minden egyes szakaszban kifejlesztett részrendszer értékelésre került, amelyhez kapcsolódóan, az eredeti követelményeket az ott felmerült igényekkel kiegészítve került sor a második részrendszer előállítására. A kutatás legvégén a 
jelenleg is zajló döntés-elökészítési folyamatba való beilleszthetőségét vizsgáltam meg.

A kutatás módszertana ezt a rendszerfejlesztési módszertant követi oly módon, hogy az egyes hipotézisek a szakaszokban kifejlesztett részrendszerekkel szembeni követelményeket képviselik, vagyis a szakasz termékének értékelése alapján kerülnek elfogadásra, vagy elvetésre.

A H.1 hipotézisben megfogalmazott, a rendszerrel szembeni elsődleges követelmény volt, hogy térben és időben strukturálva képezze le a munkaerőpiac kínálati oldalán a szakmastruktúrát, míg a keresleti oldalán a foglalkozási struktúrát mégpedig oly módon, hogy már előkészítse a következő fejlesztési fázist, azaz lehetővé tegye a két struktúra kompetencia alapon való összeilleszthetőségét.

A munkaerőpiac két oldala más kontextusra helyezi a hangsúlyt a kompetencia kezelése során, azonban a mögöttes tartalmat - tudás, képesség, attitüd - minden meghatározás tükröz, még ha más határvonalak mentén metszik is el ezeket. A kialakított ontológia alapú meta-modellek nagy előnye, hogy az összehasonlítást a kompetencia-elemekre fókuszálva, azokat az oldalak igényeinek megfelelő kontextusba helyezve tudta elökészíteni.

A szakirodalomban már számos meta-modell született ebben a témában, ezért elég volt ezeket az adott feladat alapján módosítani. A meta-modellek implementálására olyan ontológia-szerkesztő környezetet választottam ki, amely magában rejtette a következő fázissal való összeilleszthetőséget is.

Ahhoz, hogy a szakma-, illetve a foglalkozási struktúra térben és időben jól tükrözze a munkaerőpiac két oldalának kompetencia-tartalmait szükség volt a meta-modellek bővítésére. Ehhez olyan forrásokat kellett keresni, amelyek mindamellett, hogy jól tükrözik az adott állapotot, magukban hordozzák az esetlegesen bekövetkező változásokat is. A munkaerőpiac kínálati oldalán a Gazdaságinformatikus képzést oktató tanárok szakmai véleménye alapján bővült ki a KKKO ontológia meta-modellje, míg az MLO ontológia meta-modellje a keresleti oldalon az interneten megjelenő állásajánlatok alapján változott meg.

A 2010. december 27. és 2011. április 10. között letöltött, közel negyedéves gyüjtemény adta a tanító halmazt, vagyis ami felépítette az MLO ontológia elsődleges változatát. A kompetenciák kontextusát adó feladatok kinyerését DOS Batch progra- 
mok, gawk és gsar scriptek, valamint JAVA program végezte el. A félig struktúrált XHTML - formában lévő fájlok nehézkes feldolgozására utal az is, hogy mire a kontextust adó blokkokat tartalmazó fájlok leszürésre kerültek, már csak az állásajánlatgyüjtemény 10,76\%-át tudtam csak a fejlesztésre használni. A jövőben érdemesebb más, közös blokkok keresése az ajánlatokban.

Az MLO ontológia meta-modellje első körben a Szoftverfejlesztő munkakörhöz kapcsolódó 8 feladattal bővült. Ennek új osztályokkal való kiegészítésére, valamint a végső változat 2012. októberi állásajánlatok alapján történő példányosításához ontológia tanulási technikát kellett használnom, ugyanis tiszta szövegből ontológia elemek létrehozására volt szükség. A szövegekben megfigyelt mintázatok (birtokos szerkezetek) alapján olyan kifejezés-gyüjteményt alakítottam ki, amely az előbb említett feladatokhoz kapcsolódó mintázatokat adja meg nyitott kérdések - a példányosítás esetében már belőlük képezett kifejezések - , vagy jellemző szavak formájában. Látható volt, hogy az osztályokkal való bővítés során a gyüjtemény finomításával a találati arány közel megduplázódott (18,6\%-ról 33\%-ra). A kapott új osztályokat 91\%-ban jellemezték a szótárban megadott kifejezések, amelyek közül 27,6\% más feladathoz került átsorolásra, azaz az algoritmus rossz osztály alá sorolta be őket. Az is megfigyelhető volt, hogy ez főleg azokban az esetekben következett be, amikor nyitott kérdések helyett a jellemző szavak alapján kereste az alosztályokat. A jövőben a kifejezés-gyüjtemény elsősorban nyitott kérdésekkel való bővítésével lehetne tovább növelni a feldolgozási, valamint a találati arányt.

Láthatóan az ontológiai tanulás önmagában nem épít fel egy konzisztens ontológiát, szakértői vélemény szükséges a találatok ellenőrzéséhez. Az álláshirdetések gyengesége, hogy bár a hirdetők a feladatköröket kellő részletezettséggel felsorolják, azonban az elvárásokat, követelményeket, azaz a kompetenciákat tartalmazó blokkokat elnagyolják, vagy elhanyagolják (pl. csak annyit adnak meg, hogy szakirányú végzettség, angol nyelv ismerete.) Ezért a letisztított ontológiában szereplő feladatokhoz kapcsolódó tudásterületeket a TOGAF kompetenciáiból nyertük ki. Azért is jó választás, mert iparági szakértők fogalmazták meg benne a vállalati architektúra kialakításáért felelős személlyel szemben elvárásaikat, illeve ennek a munkakörnek egyik vetülete magában foglalja a szoftverfejlesztői munkakört is. A jövőben a program az egyes feladatokhoz kapcsolódó tudáselemek TOGAF-ban, illetve az állásajánlatok- 
ban megjelenő viszonyának vizsgálatával kibővíthető, akár az alkalmazott ontológiai tanulás útját követve is.

A meta-modellek aktuális körülmények közötti használata során az egyes tudáselemek példányosításra kerültek annak alapján, hogy mely régiót, milyen időszakot, illetve milyen tudásszintet kívánnak meg a felhasználási körülményeik. Mivel a prototípus alapjául budapesti képzés szolgált, valamint az állásajánlatok említett időszakban való vizsgálata során kiderült, hogy 2009, illetve 2012 megfelelő időszakban az ajánlatok 74\%-a budapesti munkavégzéssel lett meghirdetve, ezért a KKKO tudáselemei budapesti régiót érintően lettek példányosítva, 2012. évre vonatkozóan.

Az MLO ontológiában a 2012. októberében igényelt feladatok köréhez kapcsolt tudáselemek kerültek példányosításra. A BSc szintű ajánlatokban szereplő feladatok 49,75\%-os feldolgozási aránnyal, az előbb említett kifejezés-gyüjtemény segítségével kerültek feldolgozásra, amelynek eredményeként 7 tudásterületet azonosítottak, ezzel előkészítve a következő fázist.

A fejlesztés második fázisában olyan informatikai alapú megoldás keresése, vagy fejlesztése volt a cél, amely segítségével a szakma- és a foglalkozási struktúra közötti egyezőségek és különbözőségek tételesen feltárhatóak. Emellett, a H.2 hipotézisben megfogalmazott követelmény mellett még felmerült az az igény is, hogy az előző fázisban kiválaszott ontológiaszerkesztő eszköz, azaz a Protégé 4.1 kimenetével öszszeintegrálható megoldást kapjunk. Az ontológiaillesztést lehetővé tevő módszerek, eszközök vizsgálata során a dinamikus illeszkedésvizsgálat, változáskezelés, modularitás terén a - a MAFRA Toolkit elavultsága miatt - a Protégé 4.2 OWL Diff pluginja, illetve beépített Compare Ontologies funkciója maradt egyedüli választásként. Mégsem érzem a többi eszköz vizsgálatát feleslegesnek. Ugyanis a két Protégé ontológia-illesztő eszköz az egyező nevü, azonos attribútumokkal rendelkező példányok esetében tökéletes egyezőséget produkált, azonban kívánnivalót hagyott maga után az elnevezésekben a szinonímák kezelése, valamint az azonos attribútumok átfedésének vizsgálata tekintetében. Mivel ezek az eszközök nyílt forráskódúak, ezért a vizsgált ontológia-illesztő eszközök módszerei (pl. LOM és QOM esetében) segítségül lehetnek az algoritmusok pontosításában. A két eszköz közül jelenleg az OWL Diff adott áttekinthetőbb outputot. 
Összességében a fejlesztett rendszer az egyes fázisokhoz kapcsolódó követelményeknek eleget tett, azaz az első két hipotézist igazolta. Azonban számos olyan „gyengeséggel” bír, amely még a jövőben fejlesztésre szorul. Az alábbi táblázat foglalja össze az erősségeket és a gyengeségeket, valamint azok fejlesztési irányait.

\section{A rendszer erőssége}

A meta-modellek a valóságot tükrözik és kontextusba helyezik a problémát.

Az ontológia-építés során a kifejezés-gyüjtemény nagy pontossággal jellemzi az ontológia-elemeket.

Az OWL Diff azonos nevü, azonos attribútumokkal rendelkező tudáselemek összeillesztése esetén $100 \%$-ban pontos találatot ad.

\begin{tabular}{|l|l|}
\hline \multicolumn{1}{|c|}{ A rendszer gyenge pontjai } & \multicolumn{1}{|c|}{ Fejlesztési irányok } \\
\hline $\begin{array}{l}\text { Félig struktúrált dokumentumokból való } \\
\text { építkezés nagyon leszúkíti a feldolgoz- } \\
\text { ható dokumentumok körét. }\end{array}$ & $\begin{array}{l}\text { Új, közös blokkok keresése az állásajánla- } \\
\text { tokban, a program bövítése ezek kezelé- } \\
\text { sével. }\end{array}$ \\
\hline $\begin{array}{l}\text { A kifejezés-gyüjteményre épülö algorit- } \\
\text { mus a feladatok kevesebb, mint a felét } \\
\text { dolgozza csak fel. }\end{array}$ & $\begin{array}{l}\text { Kifejezés-gyüjtemény bövítése, valamint } \\
\text { az adott szerepkörhöz nem kapcsolódó } \\
\text { feladatok kiszürése. }\end{array}$ \\
\hline $\begin{array}{l}\text { A kifejezés-gyüjtemény alkalmazása } \\
\text { során születnek más osztályba sorolt } \\
\text { találatok. }\end{array}$ & $\begin{array}{l}\text { A gyüjteményt több olyan nyitott kérdés- } \\
\text { sel kell bővíteni, amely nem vezet a fel- } \\
\text { dolgozási arány romlásához. }\end{array}$ \\
\hline $\begin{array}{l}\text { Összeillesztés során az OWL Diff nem } \\
\text { veszi figyelembe az egyedek hasonló } \\
\text { elnevezését, illetve az azonos attribútu- } \\
\text { mok részhalmaz-viszonyát. }\end{array}$ & $\begin{array}{l}\text { LOM, vagy a QOM módszerére építve az } \\
\text { OWL Diff algoritmus bövítése. }\end{array}$ \\
\hline $\begin{array}{l}\text { A folyamat nem tud automatikusan vég- } \\
\text { rehajtódni, mert az egyik program (pl. } \\
\text { Protégé API) kimenetét nem tudja a má- } \\
\text { sik program (pl. OWL Diff) automatiku- } \\
\text { san beolvasni. }\end{array}$ & Konvertáló algoritmus szükséges. \\
\hline
\end{tabular}


Azonban az előbb felsorolt korlátok között a rendszer használható, és tetszőleges Profession.hu állásajánlat, illetve felsőoktatási képzés irányába kibővíthető. Azaz mindezen korlátokon belül igazolja a Dr. Gábor András által adott azon koncepciót, miszerint a felsőoktatási képzés tartalma a munkaerőpiaci igények függvényében ellenörizhető. A rendszer elörejelzésekkel történő bővitésével, olyan funkcióval bírhat, amely már a felsőoktatási képzés átalakitását is lehetővé teszi, azaz versenyképes felsőoktatási portfolió jöhet létre. A rendszer a jelenlegi döntés-elökészitési folyamatba való beilleszthetösége, azaz a H.3 hipotézis nem tesztelhető, köszönhetően annak, hogy jelenleg más elgondolások, megközelítések alapján kívánja az oktatáspolitika a képzéseket átalakítani. Azonban a rendszer erősségei, valamint gyengeségeinek javíthatósága arra utal, hogy a rendszer továbbfejlesztése már hasznos eleme lehet egy, a képzések átalakítása tekintetében kompetencia alapon gondolkodó oktatáspolitikának. 


\section{Irodalomjegyzék}

Aitken, J. (1993). National Vocational Qualifications: A Review. NVQ Report. Electrotechnology, Oct-Nov, pp.19-22.

AllasTrend. (2009). Hét álláspiaci trend válságban. http://www.origo.hu/. [online]. Elérhetö: $\quad$ http://www.origo.hu/allas/tipp/20090511-het-allaspiaci-trendvalsagban.html [Letöltve 2012. június 20.].

AmsztSzerz. (1997). Amszterdami Szerződés az Európai Unióról szóló szerződés, az Európai Közösségeket létrehozó szerződések és egyes kapcsolódó okmányok módosításáról. [online]. Elérhető: eurlex.europa.eu/hu/treaties/dat/11997D/word/11997D.doc [Letöltve 2012. november 20.].

Anon. (2009). Az Európai Képesítési Keretrendszer (EKKR). [online]. Elérhető: http://www.okm.gov.hu/main.php?folderID=1139 [Letöltve 2012. november 20.].

Anon. (2012). Call 2012-2012 Selection Year 2012 Transfer of Innovation. [online]. Elérhető: $\quad \mathrm{http} / / / \mathrm{www}$.oapee.es/dctm/weboapee/pap/leonardo-da-vinci/proyectosmultilaterales-de-toi/transferencia-innovacion-nuevo/2012/informacion-ydocumentos/who-is-who2012.pdf?documentId=0901e72b81422fe8 [Letöltve 2012. november 20.].

Atkinson, R.L. et al. (1996). Pszichológia. Osiris-Századvég.

Babbie, E. (2001). Induktív és deduktív elméletalkotás. In A társadalomtudományi kutatás gyakorlata. Balassi, pp. 39-40.

Bakacsi, G. et al. (2005). Stratégiai emberi eröforrás menedzsment. Scientia Kiadó.

Balaton, K. and Dobák, M. (1991). Mennyiségi és minőségi módszerek az empirikus szervezetkutatásban. In Z. Antal-Mokos, G. Drótos, \& S. Kovács, eds. Mennyiségi és minőségi módszerek az empirikus szervezetkutatásban. Budapest: Aula Kiadó.

Barker, D. (1993). The management charter initiative: An interim assessment. Assessment \& Evaluation in Higher Education, 18(2), p.125.

DOI: http://dx.doi.org/10.1080/0260293930180204

Benthem, J. van \& Israel, D. (1999). Information Flow: The Logic of Distributed Systems, Jon Barwise and Jerry Seligman. Journal of Logic, Language and

Information. 8 (3). p.pp. 390-397. DOI:

http://dx.doi.org/10.1023/A:1008350722315

Bloom, B.S. and Krathwohl, D. R. (1956). Taxonomy of educational objectives: The classification of educational goals. Handbook I: Cognitive domain.

Bognár, K. (2010). Tudásalapú rendszerek és technológiák. [online]. Elérhető: http://www.inf.unideb.hu/ bognar/mestint4/mestint_konyv.pdf [Letöltve 2012. november 20.]. 
BoWoGroup (2005). A framework for qualifications of the European Higher Education Area. [online]. Bologna Working Group on Qualifications Frameworks. Elérhető: http://www.bologna-bergen2005.no/Docs/00-Main_doc/050218_QF_EHEA.pdf [Letöltve 2012. november 20.].

Boulter, N., Dalziel, M. and Hill, J. (1998). Achieving the Perfect Fit: How to Win with the Right People in the Right Jobs. Gulf Professional Publishing.

Bruijn, J. et al. (2006). Ontology mediation, merging, and aligning. In Semantic Web Technologies: Trends and Research in Ontology-based Systems. pp. 95-113. DOI: http://dx.doi.org/10.1002/047003033X.ch6

Cedefop. (2012). Skills supply and demand in Europa Methodological framework. [online]. Elérhetö: http://www.cedefop.europa.eu/EN/Files/5525_en.pdf [Letöltve 2012. november 20.].

Choi, N., Song, I.-Y. and Han, H. (2006). A survey on ontology mapping. ACM SIGMOD Record, 35, pp.34-41. DOI: http://dx.doi.org/10.1145/1168092.1168097

Corcho, O., Fernández-López, M. and Gómez-Pérez, A. (2003). Methodologies, tools and languages for building ontologies. Where is their meeting point? Data \& knowledge engineering, 46(1), pp.41-64. DOI: http://dx.doi.org/10.1016/S0169$\underline{023 X(02) 00195-7}$

Corvinno. (2012). A Med-Assess projekt útnak indult. [online]. Elérhető: http://www.corvinno.hu/web.nsf/do?open\&lang=hu\&tpage=hirekmed-assess_kom [Letöltve 2012. november 20.].

Cycorp. (2011). Inferencing in Cyc. [online]. Elérhetö: http://cyc.com/cyc/technology/whatiscyc_dir/howdoescycreason [Letöltve 2012. november 20.].

Denzin, N.K. and Lincoln, Y.S. (2000). The discipline and practice of qualitative research. Handbook of qualitative research, 2, pp.1-28.

Derényi, A. (2009). A képesítések dinamikája: az oktatási és szakmai standardok meghatározása és megújítása. In E. Szegedi, ed. Kompetencia, tanulási eredmények, képesitési keretrendszerek. Tempus Közalapítvány, pp. 37-60.

DeSeCo. (2005). The Definition and Selection of Key Competencies. [online]. Elérhetö: http://www.oecd.org/dataoecd/47/61/35070367.pdf [Letöltve 2012. november 20.].

Ding, Y. and Foo, S. (2002a). Ontology Research and Development. Part 1 - a Review of Ontology Generation. Journal of Information Science, 28(2), pp.123-136. DOI: http://dx.doi.org/10.1177/016555150202800204

Ding, Y. and Foo, S. (2002b). Ontology research and development. Part 2 - a review of ontology mapping and evolving. Journal of Information Science, 28(5), pp.375 388. DOI: http://dx.doi.org/10.1177/016555150202800503

Doan, A.H. et al. (2004). Ontology matching: A machine learning approach. In S. Staab \& Rudi Studer, eds. Handbook on Ontologies. pp. 385-516.

Draganidis, F. and Mentzas, G. (2006). Competency based management: a review of systems and approaches. Information Management and Computer Security, 14(1), 


\section{p.51. DOI: http://dx.doi.org/10.1108/09685220610648373}

Egodigwe, L. (2006). Pipeline to success. Black Enterprise, 36(10).

Ehrig, Marc and Staab, S. (2004). QOM - Quick Ontology Mapping. In S. A. McIlraith, D. Plexousakis, \& Frank Harmelen, eds. The Semantic Web - ISWC 2004. Berlin, Heidelberg: Springer Berlin Heidelberg, pp. 683-697.

Ehrig, Marc and Sure, Y. (2004). Ontology Mapping - An Integrated Approach. In C. J. Bussler et al., eds. The Semantic Web: Research and Applications. Berlin, Heidelberg: Springer Berlin Heidelberg, pp. 76-91. [online]. Elérhetö: http://www.springerlink.com/content/t3m6yjdeb99ft7ak/ [Letöltve 2011. május 10.]. DOI: http://dx.doi.org/10.1007/978-3-540-25956-5_6

EKKR. (2012). Az egész életen át tartó tanulás Európai Képesítési Keretrendszere. [online]. Elérhetö: http://ec.europa.eu/education/pub/pdf/general/eqf/leaflet_hu.pdf [Letöltve 2012. november 20.].

Ennis, M.R. (2008). Competency Models: A Review of the Literature and The Role of the Employment and Training Administration (ETA). US Department of Labor. [online]. Elérhető:

http://www.careerpodcasts.org/COMPETENCYMODEL/info_documents/OPDRLite ratureReview.pdf [Letöltve 2012. november 20.].

European Commission. (1999). The Bologna Declaration of 19 June 1999. [online]. Elérhetö: http://www.bologna-berlin2003.de/pdf/bologna_declaration.pdf [Letöltve 2012. november 20.].

European Commission. (2009). The Bologna Process 2020 - The European Higher Education Area in the new decade. [online]. Elérhetö: http://www.ond.vlaanderen.be/hogeronderwijs/bologna/conference/documents/leuve n_louvain-la-neuve_communiqu\%C3\%A9_april_2009.pdf [Letöltve 2012. november 20.].

Falus, I. (2006). A kompetencia fogalma és a kompetencia alapú képzés tervezése. Társadalom és Gazdaság, 28(2), pp.173-182

DOI:

http://dx.doi.org/10.1556/TarsGazd28.2006.2

. .3

Falus, I. (2009). A tudás, készségek és kompetenciák tipológiája: fogalmi tisztázás és egy prototípus létrehozása. In E. Szegedi, ed. Kompetencia, tanulási eredmények, képesitési keretrendszerek. Tempus Közalapítvány, pp. 7-17.

FelsTv. 2011. évi CCIV. törvény a nemzeti felsőoktatásról. [online]. Elérhető: http://jogszabalykereso.mhk.hu/cgi_bin/njt_doc.cgi?docid=143567.581269 [Letöltve 2012. november 20.].

Fensel, D., Davies, J. and Van Harmelen, F. (2002). Towards the semantic web: ontology-driven knowledge management. Wiley. DOI:

http://dx.doi.org/10.1002/0470858060.fmatter

Flanagan, J.C. (1954). The critical incident technique. Psychological Bulletin, 51(4), pp.327-358. DOI: http://dx.doi.org/10.1037/h0061470 
Friedman-Hill, E. (2008). Jess ${ }^{\circledR}$ the Rule Engine for the Java ${ }^{\mathrm{TM}}$ Platform. [online]. Elérhetö: http://www.jessrules.com/jess/docs/71/ [Letöltve 2012. november 20.].

Füstös, L., Meszéna, G. and Simonné, M.N. (1986). A sokváltozós adatelemzés statisztikai módszerei. Akadémiai Kiadó.

Gawk. (2010). The GNU Awk User's Guide. [online]. Elérhetö: http://www.gnu.org/software/gawk/manual/gawk.html\#Getting-Started [Letöltve 2012. november 20.].

Gábor, A., Kő, A., Szabó, I. \& Vas, R. (2008). Ontology-based Support of Knowledge Evaluation in Higher Education. In H. Jaakola, T. Tokuda, \& Y. Kiyoki, eds. Information Modelling and Knowledge Bases XIX. IOS Press, pp. 306-314.

Gegesi Kiss, P. et al. (2004). Az egész élethosszon át tartó tanulás és az infokommunikációs technológiák együttes alkalmazásának a nemzetközi-, a magyarországi helyzete és a jövöbeni fejlödés lehetöségei. Budapest.

Genesereth, M.R., Fikes, R.E. and Computer Science Department, S.U. (1992). Knowledge interchange format-version 3.0: reference manual. Citeseer.

Genesereth, M.R. and Nilsson, N.J. (1987). Logical foundations of artificial intelligence. Morgan Kaufmann Los Altos, California.

Ghiselli, E.E. (1966). The validity of occupational aptitude tests. Wiley.

Giaretta, P. and Guarino, Nicola. Ontologies and Knowledge Bases: Towards a Terminological Clarification. Towards Very Large Knowledge Bases, 1(9), pp.25-32.

Gruber, T.R. (1992). Ontolingua: A mechanism to support portable ontologies. Citeseer.

Gruber, T.R. and others. (1993). A translation approach to portable ontology specifications. Knowledge acquisition, 5(2), pp.199-220. DOI:

http://dx.doi.org/10.1006/knac.1993.1008

Guarino, N. (1995). Formal ontology, conceptual analysis and knowledge representation. International Journal of Human Computer Studies, 43(5), pp.625640. DOI: http://dx.doi.org/10.1006/ijhc.1995.1066

Guarino, Nicola, Oberle, D. and Staab, S. (2009). What Is an Ontology? In S. Staab \& Rudi Studer, eds. Handbook on Ontologies. Berlin, Heidelberg: Springer Berlin Heidelberg, pp. 1-17. DOI: http://dx.doi.org/10.1007/978-3-540-92673-3_0

Haase, P. and Völker, J. (2008). Ontology Learning and Reasoning — Dealing with Uncertainty and Inconsistency. In P. da Costa et al., eds. Uncertainty Reasoning for the Semantic Web I. Lecture Notes in Computer Science. Springer Berlin / Heidelberg, pp. 366-384. DOI: http://dx.doi.org/10.1007/978-3-540-89765-1 21

Van Heijst, G., Schreiber, A.T. and Wielinga, B.J. (1997). Using explicit ontologies in KBS development. International Journal of Human Computer Studies, 46, pp.183-292. DOI: http://dx.doi.org/10.1006/ijhc.1996.0090 
Henczi, L. (2009). Munkavállalói kompetenciák, szociális kompetenciák fejlesztési lehetôségeinek megismertetése. [online]. Elérhetö: http://www.szakkepzesicentrum.hu/data/file/kiadvany/42/munkkompetenciahenzci.pdf [Letöltve 2012. június 20.].

Henczi, L. and Zöllei, K. (2007). Kompetenciamenedzsment. Perfekt Zrt

Horrocks, I. et al. (2004). SWRL: A semantic web rule language combining OWL and RuleML. W3C Member submission, 21, p.79.

Horrocks, Ian. (2003). The FaCT System. [online]. Elérhetö: http://www.cs.man.ac.uk/ horrocks/FaCT/ [Letöltve 2011. május 28.].

HRToborzas. (2011). Új eszköz a toborzásban: online piactér. HRPortal.hu hírportál. [online]. Elérhető: http://www.hrportal.hu/hr/uj-eszkoz-a-toborzasban-onlinepiacter-20110518.html [Letöltve 2012. június 22.].

HR-XML Consortium. (2006). Competencies (Measurable Characteristics). [online]. Elérhetö: http://ns.hr-xml.org/2_4/HR-XML-2_4/CPO/Competencies.html [Letöltve 2011. május 22.].

Huhns, M.N. and Singh, M.P. (1997). Ontologies for agents. IEEE Internet Computing, 1(6), pp.81-83. DOI: http://dx.doi.org/10.1109/4236.643942

Irawan, I. (2011). The design of Spencer generic competency as a model for banking supervisors position specification in Surabaya. Journal of Economics, Business, and Accountancy | Ventura, 14(3), pp.217-224.

JobViteSRS. (2011). Jobvite Social Recruiting Survey 2011 | Results of research on recruiting through social networks. [online]. Elérhető: http://recruiting.jobvite.com/resources/social-recruiting-survey.php [Letöltve 2012. november 20.].

Juhász, M. and Takács, I. (2006). Pszichológia. Budapest: Typotex.

Kalfoglou, Y. and Schorlemmer, M. (2003). Ontology Mapping: The State of the Art. The Knowledge Engineering Review, 18(01), pp.1-31. DOI: http://dx.doi.org/10.1017/S0269888903000651

Kismihók, Gábor. (2012). Rugalmas tanulás, rugalmas munkavégzés. Az ontológia alapú tartalommenedzsment lehetőségeinek kiaknázása. Budapest: Budapesti Corvinus Egyetem. [online]. Elérhetö: http://phd.lib.uni-corvinus.hu/621/ [Letöltve 2012. november 20.].

Kismihók, G. and Mol, S.T. (2011). The OntoHR project: Bridging the gap between vocational education and the workplace. In Book of Abstracts, EAWOP 2011. University of Maastricht, pp. 194-195.

Kismihók, G., Szabó, I. and Vas, R. (2012). Six Scenarios of Exploiting an Ontology Based, Mobilized Learning Environment. International Journal of Mobile and Blended Learning (IJMBL), 4(1), pp.45-60. DOI:

http://dx.doi.org/10.4018/jmbl.2012010104

Klein, M. (2001). Combining and relating ontologies: an analysis of problems and solutions. In Workshop on ontologies and information sharing, IJCAI. pp. 53-62. 
Kovács, B. (2010). Az információtúlterhelés csökkentése szervezeti munkafolyamatrendszerekben Thesis. [online]. Elérhetö: http://phd.lib.uni-corvinus.hu/456/ [Letöltve 2012. november 20.]

Kö, A. (2004). Az információtechnológia szerepe és lehetőségei a tudásmenedzsmentben: Az ontológiaépités, mint a tudásmenedzsment eszköze. Ph.D. értekezés.

Budapest: Budapesti Corvinus Egyetem. [online]. Elérhető: http://phd.lib.unicorvinus.hu/183/1/ko_andrea.pdf [Letöltve 2012. június 20.].

Kö, A. and Futó, I. (2008). MEC Pilot Ontology. SAKE Project documentation.

Krathwohl, David R. (2002). A Revision of Bloom's Taxonomy: An Overview.

Theory into Practice, 41(4), pp.212-218.

DOI:

http://dx.doi.org/10.1207/s15430421tip4

$\underline{1042}$

Lawler, E.E. (1994). From job-based to competency-based organizations. Journal of Organizational Behavior, 15(1), pp.3-15. DOI:

http://dx.doi.org/10.1002/job.4030150103

Li, J. (2004). LOM: A Lexicon-based Ontology Mapping Tool. In Proceedings of the Performance Metrics for Intelligent Systems (PerMIS. p. 2004.

Maedche, A. et al. (2002). MAFRA - A MApping FRAmework for Distributed Ontologies. In Asunción Gómez-Pérez \& V. Richard Benjamins, eds. Knowledge Engineering and Knowledge Management: Ontologies and the Semantic Web. Berlin, Heidelberg: Springer Berlin Heidelberg, pp. 235-250. [online]. Elérhető: http://www.springerlink.com/content/n1lbatk9cdfw3j49/ [Letöltve 2011. május 18.]. DOI: http://dx.doi.org/10.1007/3-540-45810-7_23

McClelland, D.C. (1973). Testing for competence rather than for 'intelligence.' American Psychologist, 28(1), pp.1-14. DOI: http://dx.doi.org/10.1037/h0034092

Melink, M. and Pavlin, S. (2012). Employability of Graduates and Higher Education Management Systems. [online]. Elérhető: http://www.dehemspro-

ject.eu/static/uploaded/files/files/deliverables/final_report/DEHEMS_REPORT_221 02012.pdf [Letölve 2012. november 11.]. DOI:

Mischel, W. (1996). Personality and assessment. Psychology Press.

Mitra, P. and Wiederhold, G. (2002). Resolving terminological heterogeneity in ontologies. In Proceedings of the ECAI workshop on Ontologies and Semantic Interoperability.

Mitra, Prasenjit, Noy, Natasha F. and Jaiswal, A.R. (2005). OMEN: A Probabilistic Ontology Mapping Tool. In Y. Gil et al., eds. The Semantic Web - ISWC 2005. Berlin, Heidelberg: Springer Berlin Heidelberg, pp. 537-547. [online]. Elérhető: http://www.springerlink.com/content/36535wm17876447h/ [Letöltve 2011. május 11.]. 
Mochol, M. et al. (2004). Ontology-based Recruitment Process. In Workshop over Semantic technologies for Information Portals.

Mol, S.T., Kismihok, G., Vas, R., (2012). An Innovative Ontology-Driven System Supporting Personnel Selection: The OntoHR Case. International Journal of Knowledge and Learning , 8, (1-2), 41-61. DOI: http://dx.doi.org/10.1504/IJKL.2012.047549

Neches, R. et al. (1991). Enabling technology for knowledge sharing. AI magazine, 12(3), pp.36-56. DOI: http://dx.doi.org/10.1609/aimag.v12i3.902

Noy, N. F and Musen, M. A. (2000). Algorithm and tool for automated ontology merging and alignment. In Proceedings of the 17th National Conference on Artificial Intelligence (AAAI-00). Available as SMI technical report SMI-2000-0831.

Noy, Natalya F. (2004). Semantic integration: a survey of ontology-based approaches. ACM SIGMOD Record, 33, pp.65-70.

OpenGroup. (2009). The Open Group Architecture Framework TOGAF Version 9. [online]. Elérhető: http://www.opengroup.org/togaf/.[Letöltve 2013 április 15.].

OWLDiff. (2008). OWL Diff Documentation. [online]. Elérhető:

http://krizik.felk.cvut.cz/km/owldiff/documentation.html [Letöltve November 15, 2012].

OWL Working Group. (2009). OWL Web Ontology Language Overview. [online]. Elérhetö: http://www.w3.org/TR/2004/REC-owl-features-20040210/ [Letöltve 2011. május 28.].

Prøitz, T.S. (2010). Learning outcomes: What are they? Who defines them? When and where are they defined? Educational Assessment, Evaluation and Accountability, 22(2), pp.119-137. DOI: http://dx.doi.org/10.1007/s11092-010-9097-8

Purcell, J. (2001). National Vocational Qualifications and competence-based assessment for technicians-from sound principles to dogma. Education+ Training, 43(1), pp.30-39. DOI: http://dx.doi.org/10.1108/EUM0000000005413

Rowe, C. (1995). Clarifying the use of competence and competency models in recruitment, assessment and staff development. Industrial and Commercial Training, 27(11), pp.12-17. DOI: http://dx.doi.org/10.1108/00197859510100257

SAKE. (2006). Semantic-enabled Agile Knowledge-based eGovernment. [online]. Elérhetö: http://www.sake-project.org/ [Letöltve 2011. május 12.].

Sántáné-Tóth, E. (2006). Ontológia - Oktatási segédlet. [online]. Elérhető: http://people.inf.elte.hu/santa/oktatasi-anyagok/segedletek-pdf/segedlet-5.pdf [Letöltve 2012. november 20.].

Schoonover, S.C. et al. (2000). Competency-based HR applications: Results of a comprehensive survey. Arthur Andersen/Schoonover/SHRM.

Shapiro, S.C. (2011). Knowledge Representation: Logical, Philosophical, and Computational Foundations John F. Sowa Pacific Grove, CA: Brooks/Cole , 2000 , xiv +594 pp; hardbound, ISBN 0-534-94965-7 , \$67.95. Computational Linguistics, 27(2), pp.286-294. 
Shippmann, J.S. et al. (2000). The practice of competency modeling. Personnel psychology, 53(3), pp.703-740. DOI: http://dx.doi.org/10.1111/j.1744$\underline{6570.2000 . t b 00220 . x}$

Smith, B. (2002). Ontology and Information Systems. [online]. Elérhetö: http://ontology.buffalo.edu/ontology\%28PIC\%29.pdf. [Letöltve 2011. május 23.].

Sommerville, I. (2007). Szoftverrendszerek fejlesztése. Budapest: Panem.

Sowa, J. F. (2000). Knowledge representation: logical, philosophical, and computational foundations. MIT Press.

Sowa, John F. (1992). Semantic Networks. [online]. Elérhetö: http://onlinelibrary.wiley.com/doi/10.1002/0470018860.s00065/abstract [Letöltve 2011. május 28.]. DOI: http://dx.doi.org/10.1002/0470018860.s00065

Spencer, L. (1993). Competence at work: models for superior performance. New York: Wiley.

Staab, S. (2009). Handbook on Ontologies. Springer.

Studer, R., Benjamins, V. R and Fensel, D. (1998). Knowledge engineering: principles and methods. Data \& knowledge engineering, 25(1-2), pp.161-197. DOI: http://dx.doi.org/10.1016/S0169-023X(97)00056-6

$\mathrm{Su}, \mathrm{X}$. (2002). A text categorization perspective for ontology mapping: Position paper., p. 832256.

$\mathrm{Su}, \mathrm{X}$. and Ilebrekke, L. (2006). A Comparative Study of Ontology Languages and Tools. In A. B. Pidduck et al., eds. Advanced Information Systems Engineering. Berlin, Heidelberg: Springer Berlin Heidelberg, pp. 761-765. DOI: http://dx.doi.org/10.1007/3-540-47961-9 62

Szabó, I. (2011). Comparing the competence contents of demand and supply sides on the labour market. In Information Technology Interfaces (ITI), Proceedings of the ITI 2011 33rd International Conference on. pp. 345-350.

Szelestey, J. (2005). Kompetencia modell kidolgozásának elméleti háttere. [online]. Elérhetö: www.erg.bme.hu/szakkepzes/4felev/SelesteyKompetencia.pdf. [Letöltve 2012. november 15.].

Szeredi, P. (1999). A Prolog nyelv. In I. Futó, ed. Mesterséges intelligencia. Aula Kiadó, pp. 390-419.

SZKTerv. (2012). A következő lépés Széll Kálmán terv 2.0. [online]. Elérhető: http://www.kormany.hu/download/3/e8/80000/1-

A_k\%C3\%B6vetkez\%C5\%91_1\%C3\%A9p\%C3\%A9s\%20\%28SzKT\%2020\%29.pdf [Letöltve 2012. június 7.].

Támop (2009). A felsőoktatási szolgáltatások rendszerszintű fejlesztése. [online]. Elérhető: http://tamop413.ofi.hu/ [Letöltve 2011 május 23.].

Temesi, J. ed. (2011). Az Országos képesitési keretrendszer kialakitása Magyarországon. Budapest: Oktatáskutató és Fejlesztő Intézet. 
Tempus. (2006). Tuning projekt - az oktatási rendszerek finomhangolása (Bologna szeminárium). [online].

Elérhető:

http://www.tpf.hu/pages/event/index.php?page_id=199 [Letöltve 2011. május 20.].

TogafCA. (2012). The Open Group Certified Architect (Open CA) Program | The Open Group. [online]. Elérhetö:

http://www.opengroup.org/certifications/professional/open-ca?tab=2 [Letöltve 2012. november 20.].

Tót, É. (2009). Elmozdulás a tanulási eredmények irányába - politikák és gyakorlatok. In E. Szegedi, ed. Kompetencia, tanulási eredmények, képesitési keretrendszerek. Tempus Közalapítvány, pp. 17-37.

Vas, R.F. (2007). Tudásfelmérést támogató oktatási ontológia szerepe és alkalmazási lehetöségei. Thesis. Budapest: Corvinus University of Budapest. [online]. Elérhetö: http://phd.lib.uni-corvinus.hu/258/ [Letöltve 2012. november 20.].

Wielinga, B., Sandberg, J. and Schreiber, G. (1997). Methods and techniques for knowledge management: What has knowledge engineering to offer? Expert Systems with Applications, 13(1), pp.73-84. DOI: http://dx.doi.org/10.1016/S0957$\underline{4174(97) 00023-7}$

Winterton, J., Delamare - Le Deist, F. and Stringfellow, E. (2006). Typology of knowledge, skills and competences Clarification of the concept and prototype. [online]. Elérhetö: http://www.cedefop.europa.eu/EN/Files/3048_en.pdf [Letöltve January 12, 2011].

Zhou, L. (2007). Ontology learning: state of the art and open issues. Information Technology and Management, 8(3), pp.241-252. DOI: http://dx.doi.org/10.1007/s10799-007-0019-5 


\section{Függelék}

\section{1. melléklet}

A Budapesti Corvinus Egyetem Gazdaságinformatikus BSc képzésének képesítési és kimeneti követelményei

Alapfokozat birtokában a gazdaságinformatikusok - a várható szakirányokat is figyelembe véve - képesek:

- a közgazdasági és az informatikai szakterületek ismeretanyagának alkalmazására;

- az üzleti problémák IT-vel támogatott megoldására;

- $\quad$ szakképzettségüknek megfelelő feladatok felelősségteljes végrehajtására;

- az adott szakterület új ismereteinek és eredményeinek a befogadására;

- folyamatos tanulásra, saját tudásuk bővítésére, új kompetenciák elsajátítására;

- kommunikációs készségük, tárgyalóképes idegennyelv-ismeretük birtokában partnerekkel, gazdasági, közgazdasági szakemberekkel, informatikai fejlesztéseket végző munkatársakkal való hatékony együttmüködésre.

Alapfokozat birtokában a gazdaságinformatikusok - a szakirányokat is figyelembe véve - alkalmasak:

- üzleti folyamatok megértésére, elemzésére, a végrehajtást segítő szoftveralkalmazások tervezési munkáinak elvégzésére,

- egyszerübb programozási feladatok végrehajtására;

- rendszerfejlesztési elvek és módszerek alkalmazására, fejlesztőeszközök (üzleti modellezés és/vagy számítógéppel támogatott fejlesztés eszközei) használatára;

- adatbázisok tervezésével, létrehozásával és menedzselésével kapcsolatos feladatok ellátására; 
- a gazdasági alkalmazások adaptációjára, az IT -alkalmazások bevezetéséhez szükséges szervezeti változtatások kezdeményezésére, a végrehajtásban az együttmüködésére;

- az üzleti és informatikai szakemberekkel együttmüködve, felhasználva a leghatékonyabb IT-megoldásokat a gazdasági problémákra megoldási változatok készítésére, informatikai támogatás és/vagy fejlesztés kezdeményezésére, végrehajtására;

- a szervezet informatikai egységének menedzselésére, a müködtetési kockázatok kezelésére, kisebb fejlesztési és üzemeltetési projektek tervezésére és irányítására, informatikai feladatok outsourcing megoldásaiban és auditálásában az együttmüködésre;

- gazdasági alkalmazások müködtetésére, felhasználói szolgáltatások ellátására

- operatív, menedzsment-szintü és felsővezetői információigények meghatározására és kielégítésére, vállalatirányítási és döntéstámogató rendszerek használatára, kliens-szerver architektúrák és egyéb hálózati környezetek adat- és rendszermozgatási feladatainak ellátására. 


\section{2. melléklet}

Munkaköri Leírás Ontológia kapcsolatai és annak jellemzői

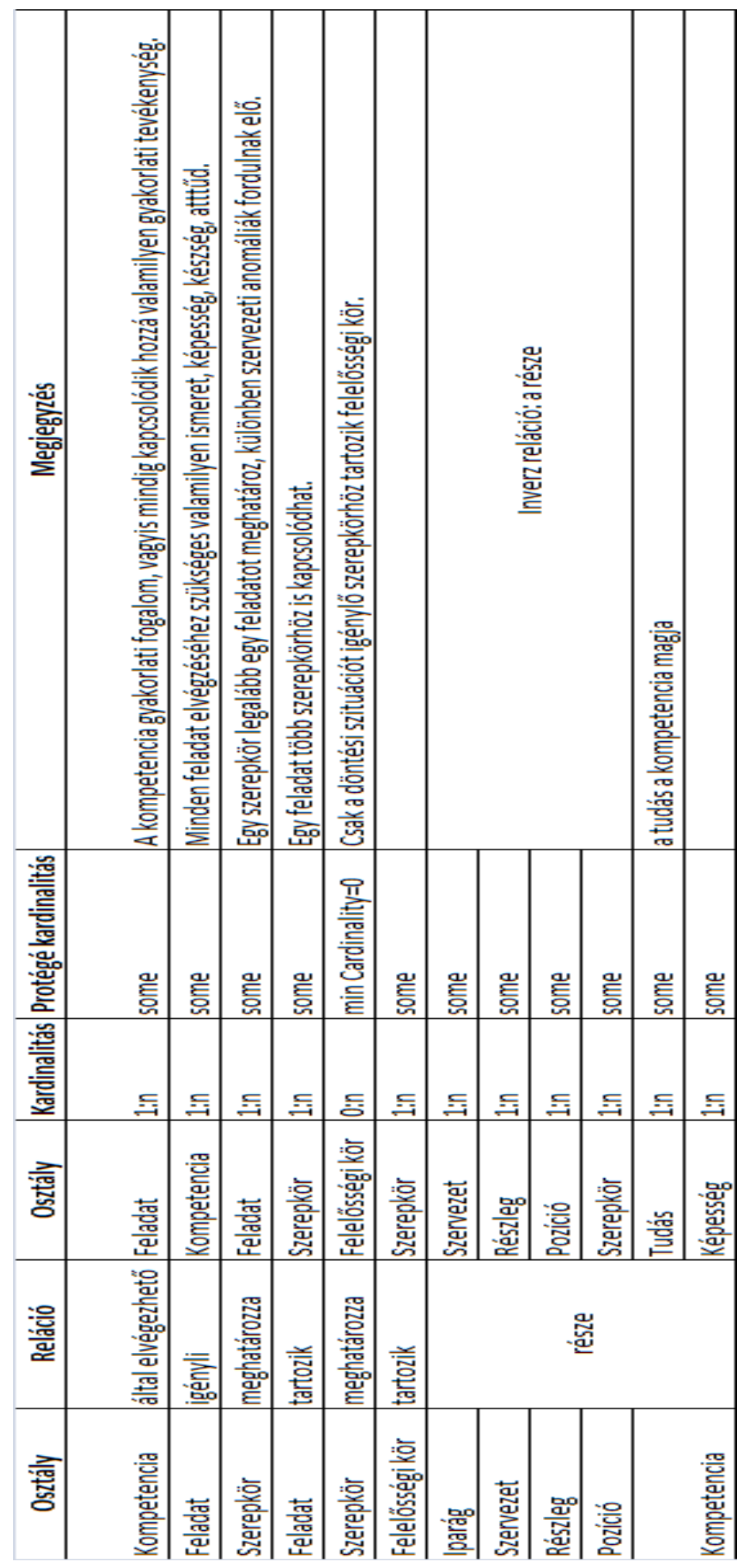




\section{3.melléklet}

A Profession.hu-n 2010. december 27. és 2011. április 10 között meghirdetett állásajánlatokban szerelő 20 leggyakoribb ige:

\begin{tabular}{|l|r|r|}
\hline words & occurrence & number of docs \\
\hline felad & 2590 & 2371 \\
\hline keres & 2090 & 2057 \\
\hline megold & 742 & 613 \\
\hline tesztel & 699 & 611 \\
\hline megbíz & 592 & 564 \\
\hline kínál & 526 & 526 \\
\hline üzemeltet & 557 & 404 \\
\hline karbantart & 437 & 376 \\
\hline ellát & 362 & 332 \\
\hline kapcsolódik & 352 & 318 \\
\hline együttmúködik & 331 & 302 \\
\hline dokumentál & 319 & 295 \\
\hline jelent & 299 & 260 \\
\hline kiválik & 265 & 250 \\
\hline bevezet & 285 & 233 \\
\hline fejleszt & 199 & 195 \\
\hline koordinál & 188 & 179 \\
\hline megfelel & 180 & 177 \\
\hline szeret & 209 & 164 \\
\hline bővül & 163 & 163 \\
\hline
\end{tabular}




\section{4. melléklet}

A javított szótárral bővített ontológia jellemző adatai

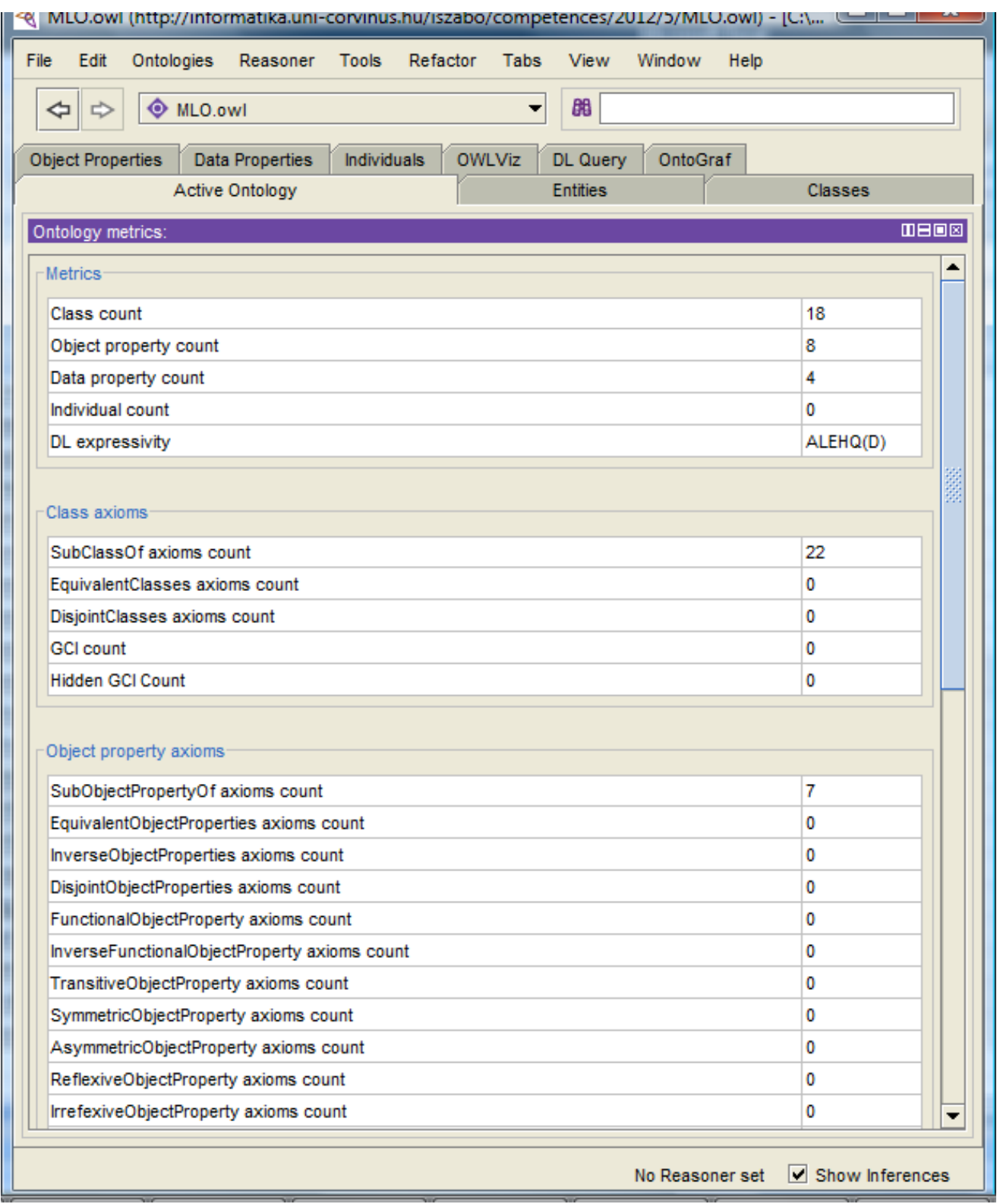




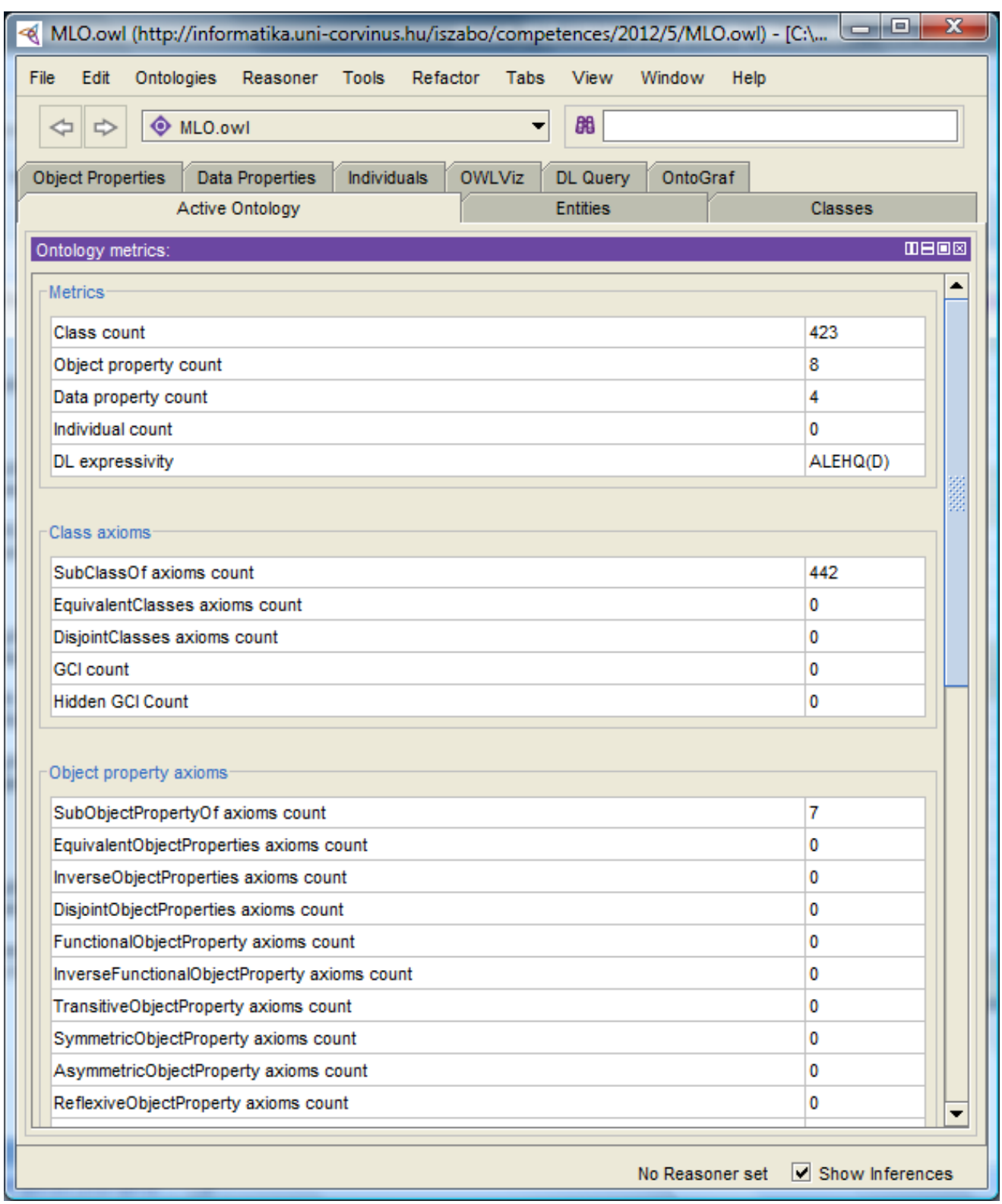

